\title{
Quantifying stand structure and structural complexity along a management gradient in temperate forests
}

\author{
Dissertation \\ zur Erlangung des Doktorgrades Dr. rer. nat. \\ der Fakultät für Forstwissenschaften und Waldökologie \\ der Georg-August-Universität Göttingen \\ vorgelegt von \\ Melissa Stiers \\ geboren am 07. Oktober 1992 in Wesel
}

Göttingen, September 2020 


\section{Gutachter:}

1. Prof. Dr. Christian Ammer

Abteilung Waldbau und Waldökologie der gemäßigten Zonen

Fakultät für Forstwissenschaften und Waldökologie

Georg-August-Universität Göttingen

Büsgenweg 1, 37077 Göttingen

2. Prof. Dr. Holger Kreft

Abteilung Biodiversität, Makroökologie und Biogeographie

Fakultät für Forstwissenschaften und Waldökologie

Georg-August-Universität Göttingen

Büsgenweg 1, 37077 Göttingen

\section{Weitere Mitglieder der Prüfungskommission:}

3. Prof. Dr. Dirk Hölscher

Abteilung Waldbau und Waldökologie der Tropen

Fakultät für Forstwissenschaften und Waldökologie

Georg-August-Universität Göttingen

Büsgenweg 1, 37077 Göttingen

4. Prof. Dr. Peter Annighöfer

Professur Wald- und Agroforstsysteme

Forschungsdepartment Ökologie und Ökosystemmanagement

Technische Universität München

Hans-Carl-von-Carlowitz-Platz 2, 85354 Freising

Tag der mündlichen Prüfung: 21.08.2020 


\section{Table of contents}

List of figures ............................................................................................................................. I

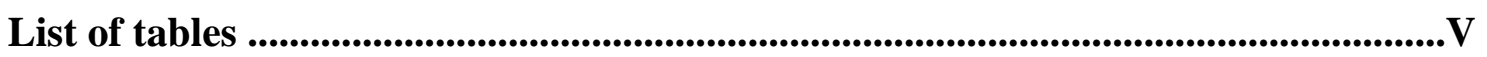

List of abbreviations ...........................................................................................................VII

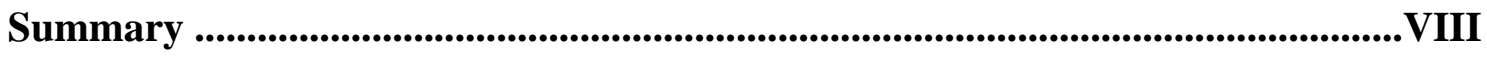

Zusammenfassung ....................................................................................................................XI

1. Chapter: Introduction ..................................................................................................... 1

1.1 Structural complexity and forests as complex systems ............................................. 3

1.2 Close-to-nature forestry based on knowledge about primary forests .......................... 6

1.3 Using TLS to quantify structural complexity .................................................... 8

1.4 Thesis objectives and hypotheses ..................................................................... 10

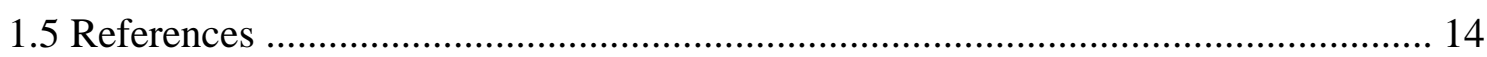

2. Chapter: A quantitative comparison of the structural complexity of managed, lately unmanaged and primary European beech (Fagus sylvatica $\mathbf{L}$.) forests ......... 22

2.1 Introduction ........................................................................................... 25

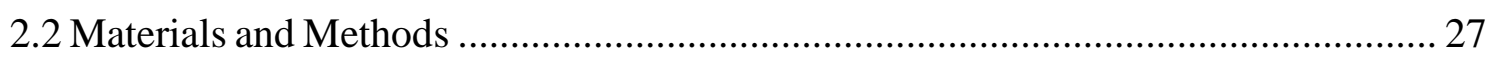

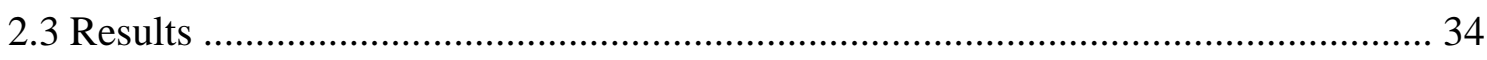

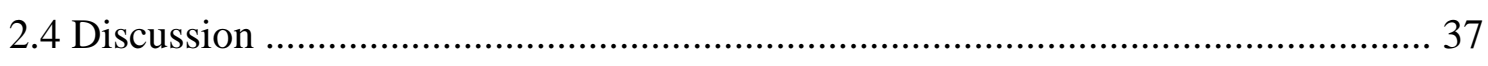

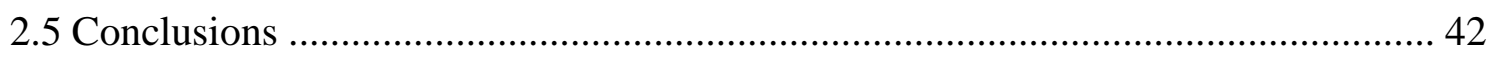

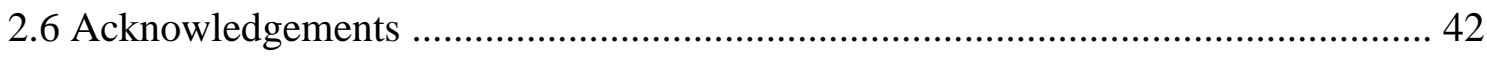

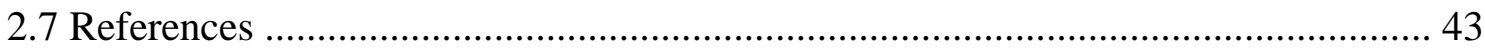

\section{Chapter: Analyzing Spatial Distribution Patterns of European}

Beech (Fagus sylvatica $\mathbf{L}$.) Regeneration in Dependence of Canopy Openings ........ 48

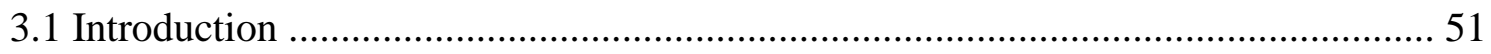

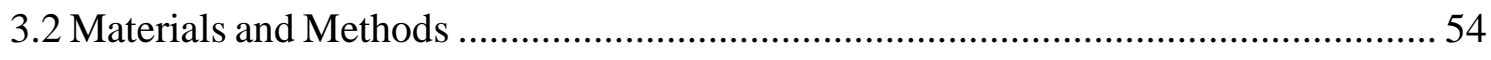

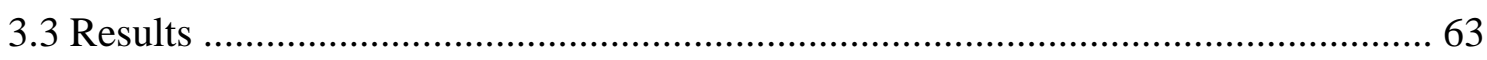

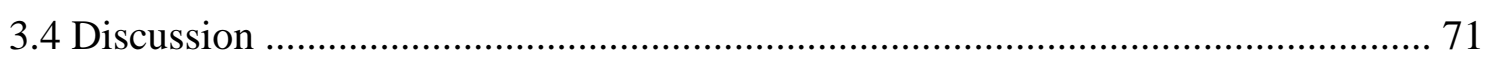

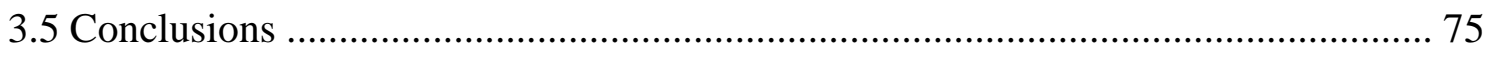

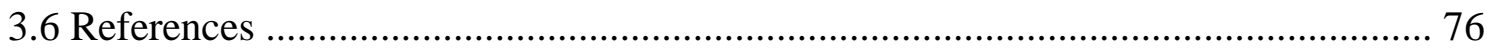




\section{Chapter: Quantifying the target state of forest stands managed}

with the continuous cover approach - revisiting Möller's "Dauerwald"

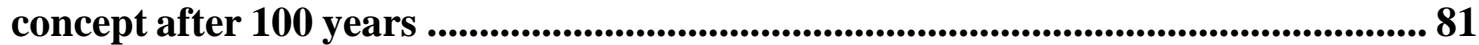

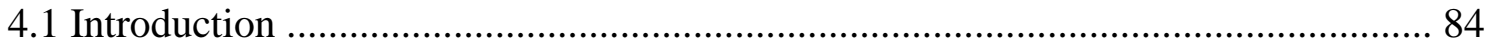

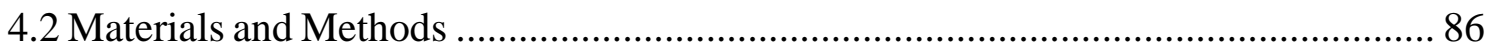

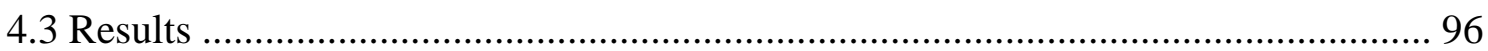

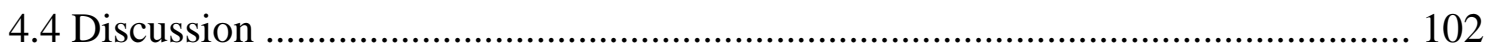

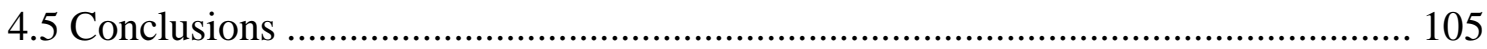

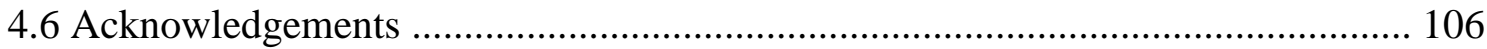

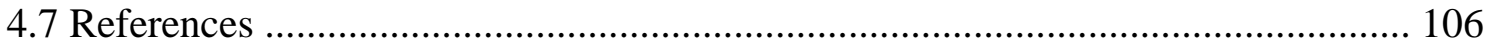

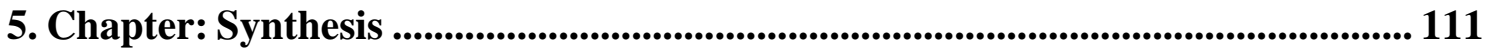

5.1 Comparisons of stand structural complexity between differently managed forests. 113

5.2 Canopy closure and its relation to structural complexity ..................................... 115

5.3 Continuous cover forestry as special type of close-to-nature forestry .................... 116

5.4 Ceasing or intensifying forest management to promote structural complexity?....... 117

5.5 Critical review of the methods applied and outlook for future research ................. 119

5.6 Conclusions and management recommendations ................................................ 121

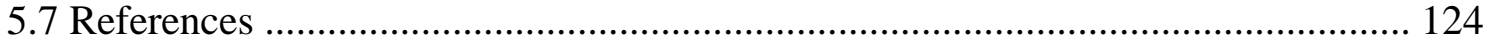

List of publications ............................................................................................................. 128

Danksagung / Acknowledgements ....................................................................................... 130

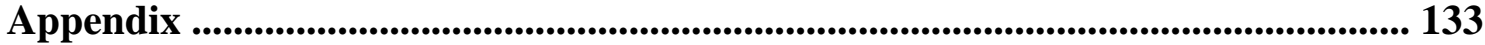




\section{List of figures}

Fig. 1.1: Simplified model of the developmental phases within the natural forest developmental cycle in beech-dominated forests modified after Begehold et al. (2015), Feldmann et al. (2018), and Král et al. (2010)

Fig. 1.2: Geographic locations of the study areas located in Germany, Slovakia and Ukraine. Black symbols mark all study areas, where data was collected in the framework of this doctoral thesis. White symbols display reference stands including data, that was not collected by the candidate itself, but used for comparison (chapter 4). Grey areas mark the potential natural distribution of European beech without human influence according to EUFORGEN (2009)

Fig. 1.3: Sampling design for an exemplary plot. In the (a) Single-scan approach, 30 Single-scans were conducted within a forest plot of 20 ha each. Minimum distance between individual single-scan was $82 \mathrm{~m}$. To reduce edge effects, a bufferzone of $20 \mathrm{~m}$ width was installed around the plot. In the (b) Multi-scan approach, an area of $50 \times 50 \mathrm{~m}$ (or $40 \times 40 \mathrm{~m}$ in chapter 4) was selected and systematically scanned with 30-90 single-scans depending on the forests density

Fig. 2.1: Distribution pattern (grey) of European beech (Fagus sylvatica L.) in Europe according to EUFORGEN (2009) and geographic locations of the eight study areas

Fig. 2.2: Examples of stands with low (left) and high (right) stand structural complexity. Left: Single-Scan in the National Park "Hainich", SSCI: 3.15 and right: Single-

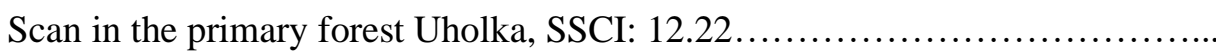

Fig. 2.3: Box-Whisker plots of stand structural complexity index (SSCI) over different management types and along a management gradient (from managed, lately unmanaged, and always unmanaged). Black horizontal lines indicate the median, black points mark the mean values.

Fig. 2.4: Box-Whisker plot of the stand structural complexity index (SSCI) for the different age classes. Black horizontal lines indicate the median, black points mark the mean values 
Fig. 2.5: Scatterplot of the stand structural complexity index (SSCI) over stand age (majority of trees). The solid black line describes the significantly non-linear trend in the data, derived from the generalized additive models $(\mathrm{p}<0.001$, $\mathrm{R} . \mathrm{adj}=0.085)$. The grey area indicates the $95 \%$ confidence interval.

Fig. 2.6: Dynamics of faunistic and floristic biodiversity and structural complexity in beech dominated forest Ecosystems in dependence of age and different forest development phases. The hypothetical chronological progression of the stand structural complexity curve was derived from the measurements and Generalized Additive Model analysis presented in Fig. 2.5. Lines for floristic and faunistic biodiversity were created according to Scherzinger (1996)

Fig. 3.1: Geographic locations of the eight study sites with their management regimes in relation to the potential natural vegetation (grey) of European beech without human influence according to the European Forest Genetic Resources Programme (EUFORGEN; 2009)

Fig. 3.2: Illustration of the three different approaches used in this study. (a) Data analysis to calculate polygon sizes, maximum extents and center positions based on manually delineated polygons. (b) Computing $10 \mathrm{~cm}$ point cloud grids to identify the maximum height within the regeneration patches. (c) Top-down analysis based on raster data of $10 \mathrm{~cm}^{2}$ resolution to analyze the top-down dependency.

Fig. 3.3: Schematic representation of the relationship between stand height (h) and maximum solar angle $(\alpha)$ and the resulting minimum diameter (d) of the canopy gap to allow incidence of direct sunlight

Fig. 3.4: Exemplary maps of horizontal (xy)-cells based on the point cloud grid of a plot, here from one of the Hainich sites. Digital surface models of gap layer (a) and regeneration layer (c), standardized 0/1 canopy layer showing the gap (b). (d-f): Elements of the regeneration layer located in the gap (d), in a buffer zone of $1 \mathrm{~m}$ around regeneration in gap (e) (here exemplary buffer zone $0-1 \mathrm{~m}$ ), and (f) remaining regeneration under densely closed canopy 
Fig. 3.5: Scatterplots of regeneration area $\left(\mathrm{m}^{2}\right)$ over gap size $\left(\mathrm{m}^{2}\right)$. (a) Non-significant relationship between gap size and resulting regeneration area based on polygon analysis. (b) Significant relationship between gap size and regeneration area based on raster data in top-down analyses. The dashed grey lines mark the 1:1 relationship between both sizes

Fig. 3.6: Box-whisker plots of the regeneration vegetation height $(m)$ in dependence of position in gap, in buffer zone ( $1-5 \mathrm{~m}$ ) or under closed canopy

Fig. 3.7: The different lines illustrate the mean height development of the regeneration relative to height in gap measured for seven classes; Gap = heights within the gap polygon; Buffer 1-5 = subsequent $1 \mathrm{~m}$ buffer zones around the gap polygon; Canopy $=$ all remaining heights under the canopy. Each line represents one of the 16 study plots; the solid black line shows the mean height decrease of all plots together

Fig. 3.8: Horizontal shift (a) of the regeneration patch center relative to the center of the canopy opening (0/0), respectively and (b) horizontal shift of the maximum height within the regeneration patch relative to the center of the regeneration patch $(0 / 0)$, respectively. Open triangles mark the position $\{x / y\}$ of the regeneration patch center (a) and open circles mark the maximum height within the patch (b). The point $(0 / 0)$ in the two-dimensional coordinate system is equivalent to the projected center of the canopy gap (a) or the center of the regeneration patch (b)

Fig. 4.1: Geographic locations of the study areas located in Germany, Slovakia, and Ukraine. Circles represent the eight study areas, which were classified as continuous cover target state forests (CCF), triangles represent the four evenaged forests, and diamonds represent the unmanaged forests

Fig. 4.2: Illustration of the voxel model and subdivisions. Black voxels mark the five lowermost bottom layers $(<1.0 \mathrm{~m})$ in the voxel model, which were deleted before data analysis (bottom black voxels), and the voxels which were deleted through the reduction of maximum stand height to median stand height (top black voxels) 
Fig. 4.3: (a) shows the weighted skewness in a standard normal distribution with stretched minimum function. The dashed horizontal lines mark the regular normal distribution (dark grey), while the dashed vertical lines mark skewness values of 0 and 1 (light grey) as well as the mean skewness (dark grey). The black solid line shows the weighted skewness with stretched values between 0 and 1. (b) shows the weighted height using a Chapman-Richards-function (4), while the dashed vertical lines represent the threshold values of 13 and $20 \mathrm{~m}$

Fig. 4.4: Accumulation curves showing the cumulative relative space filling over relative stand height. The angle bisector marks the exemplary course for a homogeneously distributed space filling, which means each stand layer is equally filled

Fig. 4.5: Box-Whisker plots of box dimension $\left(D_{b}\right)$, relative space filling and skewness of different management types: continuous cover forests (CCF), even-aged forests (EA), and primary forests (PF). Black horizontal lines indicate the median. Lowercase letters indicate significant differences between the management types $(\mathrm{p}<0.05)$

Fig. 4.6: Scatterplot of the Skewness over Box dimension. The different symbols mark the different management types investigated here

Fig. 4.7: (a) Box-Whisker plots of the index of structural constancy (ISC) (b) and stand structural complexity-index (SSCI) depending on management type and species composition: continuous cover forests (CCF), even-aged managed forests (EA), and primary forests (PF). Black horizontal lines indicate the median. Lowercase letters indicate significant differences between the management types $(\mathrm{p}<0.05)$.

Fig. 5.1: Box-whisker plots of the stand structural complexity index (SSCI) over different management types and along a management gradient (from traditionally and alternatively managed beech-dominated stands (chapter 2), managed close-tonature (CCF), and lately unmanaged National parks to always unmanaged primary forests). Black horizontal lines indicate the median, black squares mark the mean values

Fig. 5.2: An illustration of management systems on stand-level that emulate natural disturbances. Modified after Kimmins (2004) and Kuuluvainen (2009) 


\section{List of tables}

Tab. 2.1: Detailed information about the climatic and geographic conditions of the study sites. The coordinates were taken at the center of each subplot

Tab. 2.2: Descriptive statistics of stand structural complexity (SSCI) in the eight different study areas; $\min =$ minimum, $\max =$ maximum, $\mathrm{sd}=$ standard deviation, $\mathrm{cv}=$ coefficient of variance. Different lowercase letters indicate significant differences among the eight study areas at the level of $p<0.05$

Tab. 3.1: Detailed information about the climatic and geographic conditions of the study areas and the average age of the studied stands

Tab. 3.2: Detailed information about latitude, maximum solar angle, stand height and the theoretical, minimum diameter of a circular gap at which the solar radiation directly hits the forest floor, maximum regeneration height, sizes of regeneration areas and canopy gaps, as well as a description of the spatial extent of the canopy gaps in north-south (NS) or west-east directions (WE). Every time there are multiple values of gap area for one plot, several small gaps were summed-up in terms of canopy opening size, which then was the basis for averaging gap sizes and further analysis

Tab. 3.3: Mean regeneration height depending on the position of the regeneration area from within-gap over transitional buffer zones to closed-canopy. Different lower-case letters indicate significant differences between positions at the level of $p<0.05$. The degrees of freedom in all statistical tests were six. Column "p" lists the p-values that indicates the significance of the test results. The F-value in column " $\mathrm{F}$ " indicates the value of the F-distribution used to calculate the $\mathrm{p}$ value

Tab. 4.1: Detailed information on important climatic and geographical properties of the study plots:

Tab. 4.2: Descriptive statistics for the divergence from the homogeneous distribution of the continuous cover target forests (CCF), the even aged forest stands (EA), and the primary forests $(\mathrm{PF})$. Mean sum positive and mean sum negative summarize all deviations in space filling in each layer from the hypothetical equal distribution 
Tab. 4.3: Descriptive statistics for box dimension $\left(D_{b}\right)$, relative space filling $(S F)$, vertical $\left(\mathrm{E}_{\mathrm{ver}}\right)$ and horizontal ( $\mathrm{E}_{\mathrm{hor}}$ ) evenness and skewness (Skew) of continuous cover forest target stands (CCF), even-aged forest stands (EA), and primary forests (PF).

Tab. 4.4: Mean values for Db, Space filling (SF), skewness, ISC, and SSCI for the different species compositions within and between management types. Lowercase letters indicate significant differences in the indices between management types $(\mathrm{p}<0.05)$. For calculation of the SSCI in the even-aged and primary forests, single-scans were used. Therefore, only the beech forests were included in the analysis for EA, as the single-scans for the other tree species and compositions were not available. 


\section{List of abbreviations}

ALS Airborne laser scanning

$\mathrm{CCF}$ Continuous cover forestry/forests

$\mathrm{CV} \quad$ Coefficient of Variation

$\mathrm{D}_{\mathrm{b}} \quad$ Box dimension

DSM Digital surface model

DTM Digital terrain model

EA Even-aged forest

ISC Index for structural constancy

LiDAR Light Detecting and Ranging

MAP Mean annual precipitation (mm)

MAT Mean annual temperature $\left({ }^{\circ} \mathrm{C}\right)$

MLS Mobile laser scanning

PF Primary forest

SD Standard deviation

SSCI Stand structural complexity-index

TLS Terrestrial laser scanning

UCI Understory complexity-index 


\section{Summary}

The structure and structural complexity of forests influence many important characteristics of forest ecosystems, as well as their functions and services, such as ecosystem stability, maintenance of biodiversity and carbon storage. Forest management affects the spatial structures of forests and thus has an impact on many of these services and functions offered by forest ecosystems. In this context, it is often discussed whether forest management has a reducing or promoting effect on the structural complexity of a forest stand. In order to answer this question, it is essential to gain a better understanding of the development, properties and dynamics of structural complexity in forests. This doctoral thesis will contribute to this by studying different aspects of structural complexity in forests using highly detailed, three-dimensional terrestrial laser scanning data.

The first aim of this thesis was to quantify the structural complexity of forests along a gradient of management intensity in order to analyze the effects of forest management. In a first study (chapter 2), the structural complexity of traditionally and alternatively managed forests, lately unmanaged forests in German National Parks, and completely unmanaged primary forests of European beech (Fagus sylvatica L.) in the Western Carpathians was quantified using a stand structural complexity index (SSCI). It was found that structural complexity does not increase linearly with decreasing management intensity but that management can promote structural complexity. The lowest structural complexity was found in the lately unmanaged National Parks, while stands of younger developmental phases of traditional management do not differ significantly from the structural complexity found in one of the primary forests. Furthermore, differences in structural complexity could be identified between different phases of forest development. While the structural complexity in so-called "vault-like" forests, single-layered stands in the optimum phase, is minimal, it is increased by the multi-layered structures in, for example, thickets with overstory trees.

The emergence of natural regeneration is decisive for the establishment of multiple stand layers and thus for the future structural development of a forest stand. Therefore, a second study (chapter 3 ) focused on the analysis of the structural complexity of natural regeneration of European beech and the identification of spatial distribution patterns of regeneration patches in dependence of canopy gap characteristics. Unravelling the mechanisms behind such spatial top-down-relationships between canopy gaps and natural 
regeneration is helpful to control and manage the regeneration's composition and development. A significant positive relationship between gap size and the size of a regeneration patch was found in beech forests. However, no homogeneous, significant offset between the centers of the regeneration patch and the projected gap polygon could be identified, as was the case in literature for the regeneration of other, mostly lightdemanding tree species. Furthermore, it could be shown that the mean regeneration height continuously decreases from positions within the projected gap polygon to positions under closed canopy in the adjacent stand. However, the largest plants were not located directly in the center of the gap polygon, but at the outer edges of the projected gap polygon. Furthermore, it was determined that natural regeneration of beech benefits from the higher amount of diffuse radiation outside the gap polygon, which is why it can be concluded that the emergence of natural regeneration is also promoted in the penumbral zone. Overall, these results once again confirmed the high shade-tolerance of beech. Therefore, we conclude that the effect of higher availability of direct or diffuse radiation in and around canopy gaps may be overruled by other factors, such as competition with mature trees.

This thesis also aimed at identifying management systems that can lead to an increase in stand structural complexity. In a third study (chapter 4), the focus was therefore on quantifying the structural complexity of forests, which have been managed according to the guidelines of continuous cover forestry for several decades. We compared their structure with that of traditional age-class forests and completely unmanaged primary beech forests. Continuous cover forestry is of particular interest because it aims at a target state, which includes multi-layered, highly-structured forests, which fulfill both economic and social demands. In order to objectively quantify the structures of this target state, a new index for structural constancy (ISC) was developed. In addition, already established indices for the description of the spatial forest structure were calculated. The new ISC was able to distinguish continuous cover forests and even-aged age-class forests. However, we were not able to detect a significant difference between the continuous cover forests and the primary beech forests as natural reference. Overall, it could therefore be concluded that continuous cover forestry is capable of creating forest stands of high structural complexity.

Finally, based on the results of the three studies presented here, we derived management recommendations, which intend to enable forest managers to promote structural 
complexity in forests. In order to generate a high degree of vertical and horizontal heterogeneity, management methods should be chosen that create differently sized and shaped canopy gaps to diversify growth conditions. To promote structural complexity not only at stand level, but also at larger, regional scale, structural heterogeneity between neighboring stands should also be increased. While both ceasing and intensifying forest management do not lead to a rapid increase in structural complexity, it was first noted that traditional forest management is capable of disrupting phases of low structural complexity during stand development and thus promoting structural complexity. Furthermore, the results of this thesis allow the conclusion that continuous cover forestry according to the principles of close-to-nature forest management is particularly suitable to produce sustainable forests with a high degree of multifunctionality and a stand structural complexity similar to primary forests.

We therefore conclude that forest management does not necessarily lead to a simplification of the structural complexity, but that specific management systems and methods can increase structural complexity and thus also enhance the associated properties of the forest ecosystem. 


\section{Zusammenfassung}

Die Struktur und die strukturelle Komplexität von Wäldern beeinflussen zahlreiche wichtige Eigenschaften von Waldökosystemen, sowie auch deren Funktionen und Dienstleistungen, wie beispielsweise die Ökosystemstabilität, die Erhaltung der Biodiversität und die Kohlenstoffspeicherung. Die Bewirtschaftung von Wäldern verändert deren räumliche Struktur und übt somit auch einen Einfluss auf viele Leistungen und Funktionen von Waldökosystemen aus. In diesem Zusammenhang wird häufig diskutiert, ob Forstwirtschaft sich vereinfachend oder sogar fördernd auf die strukturelle Komplexität eines Waldbestandes auswirkt. Zur Beantwortung dieser Frage ist es unabdingbar, die Entstehung, die Eigenschaften und die Dynamik der strukturellen Komplexität in Wäldern zu untersuchen. Dazu soll diese Arbeit einen Beitrag leisten, indem verschiedene Aspekte der strukturellen Komplexität von Wäldern mithilfe von detaillierten, dreidimensionalen Laserscanningdaten untersucht werden.

Ein Ziel dieser Arbeit bestand darin, die strukturelle Komplexität unterschiedlicher Wälder entlang eines Gradienten der Managementintensität zu quantifizieren, um somit den Einfluss der Bewirtschaftung zu analysieren. In einer ersten Studie wurde dazu die strukturelle Komplexität von traditionell bewirtschafteten Wäldern, alternativen Bewirtschaftungssystemen und stillgelegten Wäldern in deutschen Nationalparken, bis hin zu vollständig unbewirtschafteten Buchen-Urwäldern (Fagus sylvatica L.) der Westkarpaten mithilfe eines Indexes zur Beschreibung der Strukturkomplexität (engl.: stand structural complexity-index, SSCI) quantifiziert. Dabei konnte festgestellt werden, dass die strukturelle Komplexität nicht mit sinkender Managementintensität linear ansteigt, sondern dass Bewirtschaftung die strukturelle Komplexität fördern kann. Es fand sich die geringste strukturelle Komplexität in den stillgelegten Wäldern der Nationalparke, während jüngere Altersklassen traditioneller Bewirtschaftung sich nicht grundsätzlich signifikant von der in einem der Urwälder festgestellten Strukturkomplexität unterscheiden. Des Weiteren ließen sich Unterschiede in der strukturellen Komplexität zwischen verschiedenen Waldentwicklungsphasen ausweisen. Während die Strukturkomplexität in den so genannten „Buchen-Hallenwäldern“, einschichtigen Beständen der Optimalphase, minimal ist, wird sie durch einen mehrschichtigen Aufbau, wie beispielsweise in jüngeren Bestandesentwicklungsphasen durch den Erhalt von Überhältern erhöht. 
Da das Aufkommen von natürlicher Verjüngung für die Etablierung mehrerer Bestandessschichten und somit für den zukünftigen, strukturellen Aufbau eines Bestandes entscheidend ist, lag der Fokus in einer zweiten Studie (Kapitel 3) auf der Analyse der strukturellen Komplexität von Buchen-Naturverjüngung und der Identifizierung räumlicher Verteilungsmuster in und von Verjüngungskegeln in Abhängigkeit verschiedener Eigenschaften der Kronenlücken. Ein besseres Verständnis solch räumlicher Zusammenhänge zwischen Kronenlücken und dem Aufkommen und der Verteilung natürlicher Verjüngung ist nützlich, um deren Zusammensetzung und Entwicklung $\mathrm{zu}$ kontrollieren und $\mathrm{zu}$ steuern. Es wurde ein signifikant positiver Zusammenhang zwischen der Größe einer Kronenlücke und der Größe eines Verjüngungskegels in Buchenwäldern festgestellt. Es fand sich jedoch kein einheitlicher, signifikanter Versatz des Kegelzentrums zum projizierten Kronenlückenzentrum für natürliche Verjüngung der Buche, wie es in der Literatur für andere, meist lichtliebende Baumarten der Fall war. Darüber hinaus konnte nachgewiesen werden, dass die Höhe der Buchen-Verjüngungspflanzen von Positionen innerhalb des projizierten Lückenpolygons bis in den umliegenden Bestand kontinuierlich abnimmt. Die größten Pflanzen befanden sich dabei allerdings nicht im Lückenzentrum, sondern in den Übergangsbereichen zum angrenzenden, geschlossenen Bestand. Weiterhin wurde gezeigt, dass BuchenNaturverjüngung auch außerhalb des projizierten Lückenpolygons vom Anstieg des diffusen Lichtes profitiert und das Aufkommen von Verjüngung somit auch in der penumbralen Zone gefördert wird. Insgesamt bestätigten die Ergebnisse erneut die hohe Schattentoleranz der Buche und lassen somit die Schlussfolgerung zu, dass der Effekt des Anstiegs der direkten und diffusen Lichtverfügbarkeit durch andere Faktoren, wie beispielsweise der Konkurrenz zu Altbäumen beeinträchtigt wird.

Ein weiteres Ziel dieser Arbeit war es, Managementsysteme und -maßnahmen zu identifizieren, die zu einer Erhöhung der strukturellen Komplexität führen können. In einer dritten Studie (Kapitel 4) lag der Fokus deshalb auf der Quantifizierung der strukturellen Komplexität von Wäldern, die bereits mehrere Jahrzehnte nach den Vorgaben der Dauerwaldwirtschaft bewirtschaftet wurden und deren Vergleich mit traditionellen Altersklassenwäldern und unbewirtschafteten Buchen-Urwäldern. Die Dauerwaldwirtschaft ist von besonderem Interesse, da sie einen Zielzustand anstrebt, der mehrschichtige, hochstrukturierte Wälder vorsieht, die sowohl wirtschaftliche, als auch gesellschaftliche und ökologische Ansprüche gleichermaßen erfüllen. Um diesen Zielzustand objektiv zu quantifizieren und so vergleichbar zu machen, wurde neben der 
Berechnung bereits bekannter Indices zur Beschreibung der räumlichen Waldstruktur ein neues skaliertes Maß (engl.: index for structural constancy, ISC) entwickelt, welches den aktuellen Zustand eines Waldes hinsichtlich seiner Struktur und strukturellen Komplexität mit einem hypothetischen Idealzustand vergleicht. Der neue ISC war auf diese Weise in der Lage Dauerwälder signifikant von Altersklassenwäldern zu unterscheiden. Es fand sich jedoch kein signifikanter Unterschied zu den BuchenUrwäldern als natürliche Referenz. Insgesamt konnte geschlussfolgert werden, dass die Dauerwaldwirtschaft in der Lage ist, strukturell hoch komplexe Bestände zu erzeugen.

Anhand der Ergebnisse der vorliegenden drei Studien wurden abschließend Managementempfehlungen abgeleitet, die es ermöglichen sollen, strukturelle Komplexität in Wäldern zu fördern. Um ein hohes Maß an vertikaler und horizontaler Heterogenität zu generieren und unterschiedliche Wuchsbedingungen zu schaffen, sollten Managementmethoden gewählt werden, die Kronenlücken in verschiedenen Größen und Formen erzeugen. Zur Förderung der strukturellen Komplexität nicht nur auf Bestandessondern auch auf regionaler Ebene, sollte auch die strukturelle Heterogenität zwischen benachbarten Beständen erhöht werden. Während sowohl eine Stilllegung, als auch eine Intensivierung der Bewirtschaftung nicht zu einer schnellen Erhöhung der strukturellen Komplexität führt, konnte zunächst festgestellt werden, dass traditionelle Bewirtschaftung in der Lage ist, Phasen geringer struktureller Komplexität zu durchbrechen und die Strukturkomplexität so zu fördern. Darüber hinaus lassen die Ergebnisse dieser Arbeit den Schluss zu, dass insbesondere die naturnahe Waldbewirtschaftung nach den Prinzipien der Dauerwaldwirtschaft geeignet ist, zukunftsfähige Wälder mit einem hohen Maß an Multifunktionalität und struktureller Komplexität zu erzeugen.

Wir kommen daher zu dem Schluss, dass Waldbewirtschaftung nicht zwangsläufig eine Simplifizierung der strukturellen Komplexität und damit verbunden eine Reduzierung der Ökosystemleistungen bewirkt, sondern dass gezielte Bewirtschaftungsweisen die Strukturkomplexität steigern und somit auch die damit verbundenen Eigenschaften des Waldökosystems fördern können. 
Chapter 1

Introduction 


\section{Introduction}

Forest ecosystems provide numerous ecosystem functions and services such as harboring biodiversity (Lindenmayer et al. 2000), climate regulation (Thompson et al. 2009), the protection of soil and water resources (Beets et al. 2002, Abildtrup et al. 2013), timber production or human recreation (Gustafsson et al. 2012, Ribe 2009). Nevertheless, the requirements placed on forests are constantly increasing. For several decades now, the demand for near-natural, multifunctional forests in particular has increased. Forests are considered to play a key role in climate change, as their structural complexity and heterogeneity are hypothesized to promote ecosystem resilience and adaption (Augustynczik et al. 2020, McElhinny et al. 2005, Neill and Puettmann 2013, and Thompson et al. 2009). This is why management systems are being sought that promote multifunctionality (Bauhus et al. 2009, Diaci et al. 2011, and Mizunaga et al. 2010). To develop such management systems, it is necessary to understand forest ecosystems, their organization and their structures in order to identify the influence of forest management. This thesis will contribute to this general aim of forest sciences by quantifying the structural differences of managed forests along a gradient of management intensity compared to natural primary forests of the temperate zones (chapter 2), studying spatial and structural dependencies within upper and lower stand layers (chapter 3), and evaluating a specific type of close-to-nature forestry by using a newly developed index for structural constancy (chapter 4).

Forest management objectives change with social demands and community values (Chazdon et al. 2016), which in turn has a direct influence on management systems (Parrot and Lange 2013). Due to constantly growing demands for natural forest development, more and more natural processes are being integrated in forest management systems. This results in conflicts of interest, especially between timber production and ecosystem conservation (Gustafsson et al. 2012). Therefore, there was a strict spatial segregation of these two interests and the establishment of specific "set-aside" conservation areas in the past (Kuuluvainen 2009, Schütz 1999b). Nowadays more common than the segregational approach are concepts integrating timber production and nature conservation on the same area. (Bollmann and Braunisch 2013, Borrass et al. 2016). In these integrative systems, the type of forest management is of particular importance (Levin 2005). It can range from traditional, yield-oriented systems, to extensive forms or alternative concepts integrating specific nature conservation strategies. 
The latter were created by the requirement for a so-called "close-to-nature-forestry" that promotes the multifunctional character of a forest stand. Thus, forestry in most central European countries has been undergoing radical change from even-aged clearcuts and shelterwood-systems to uneven-aged systems. These are named differently as "close-tonature", "back-to-nature", or "near-natural", but all mean the same: the transition from traditional even-aged management systems to multifunctional, uneven-aged, heterogeneous forest stands with high structural diversity (Diaci 2006, Mizunaga et al. 2010, O'Hara 2001, O’Hara et al. 2007, Puettmann et al. 2015, and Schabel and Palmer 1999).

\subsection{Structural complexity and forests as complex systems}

Changes in forest management are reflections of a fundamental change in the ecological understanding of forests as complex ecosystems (Fahey et al. 2018, Kuuluvainen 2009, Parrot and Lange 2013). Forest ecosystems in general meet the characteristics of complex systems (Levin 2005, Parrot and Lange 2013). More specifically, forests typically exhibit the following properties of complex systems: First, forest ecosystems are open systems, exchanging energy, material and information. Second, as open systems, it is difficult to determine the boundaries of forest ecosystems. Visible boundaries in managed forests are often artifacts of the stand-wise management model. Third, prior states may have a strong influence on present and future states. Fourth, forest ecosystems consist of subsystems that can mostly be described as complex systems themselves, e.g. animal and plant populations. These subsystems are also interconnected as dynamic networks in food chains or other local interactions of the ecosystem components such as trees, other plants, insects and soil organisms. Fifth, forest ecosystems exhibit adaptive properties such as resistance and resilience, which result from the interactions within the systems and which are therefore difficult to study and/or predict. Resilience is a property in the context of adaptive systems, which is defined as the degree of disturbance that can be buffered by a system before its structure changes in a way that affects system functioning (Parrot and Lange 2013). Finally, all these subsystems, properties and interactions are not linear, which means that even small disturbances or influences can, but do not have to, have large effects (Parrot and Lange 2013). A current example can be a small change in the climatic conditions, which causes a rapid change in the system, which then manifests itself, for example, in a changed disturbance regime (Kuuluvainen 2009, Levin 2005). 
Forest ecosystems as complex systems are characterized by the forest structure, called stand structure on stand level, which is in general described and characterized by the way the trees are distributed within the forests (v. Gadow et al. 2012). On closer consideration, stand structure consists of two components: stand structural attributes and stand structural complexity (McElhinny et al. 2005). However, these components are directly interdependent. Stand structural complexity is defined differently in the literature. Here, we used the definition of Seidel et al. (2019b), who defined stand structural complexity as "a summarizing term describing all dimensional, architectural and distributional patterns of plant individuals and their organs in a given forest space at a given point in time". According to Pretzsch (2009), the three-dimensional character of a forest is the most important property concerning its structural complexity. McElhinny et al. (2005) collected some key structural attributes in different stand elements that can affect stand structural complexity: foliage and its spatial distribution, canopy cover, stand biomass, understory vegetation and tree-based attributes such as diameter, height and spacing, species identity and species diversity. These attributes are often interdependent as well, for example, canopy opening or vertical multi-layering could be predictors for species composition or variance of tree diameters (Franklin et al. 2002).

The range of tree diameters belongs to the size or spatial variation measures, which play a special role in the definition of structural complexity, because they could indicate the small-scale heterogeneity of an ecosystem, which in turn is fundamental to other forest functions, such as biodiversity (Lindenmayer et al. 2000, Tews et al. 2004). Thus, the range of tree diameters is often used to describe vertical heterogeneity in forests, because generally, for shade-tolerant species there is a strong link between tree diameter and height (Podlaski et al. 2019). Another structural characteristic that drives ecosystem heterogeneity is the spatial distribution of canopy gaps. These canopy gap patterns and gap dynamics are frequently studied (Bottero et al. 2011, Hobi et al. 2015, and Yamamoto 2000), but there is only little research focused on the spatial relationship between gaps and existing regeneration (Canham et al. 1990), which is important for the establishment of multiple stand layers. However, it was highlighted in several studies on species diversity and ecosystem functioning that those heterogeneous forests promote the diversity of some taxa and increases multifunctionality (MacArthur and MacArthur 1961, Schall et al. 2018a, and Tews et al. 2004). This heterogeneity not only matters horizontally, but also vertically, whereby the vertical arrangement of foliage is one of the most frequently used attributes for describing stand structure (McElhinny et al. 2005). 
Already in 1961, MacArthur and MacArthur discovered a relationship between foliage height diversity and bird species diversity. In addition to the positive effect of structural complexity on forest ecosystem functioning, heterogeneous forest structure is often associated with higher productivity (Hardiman et al. 2011, Ishii et al. 2004) and greater adaptability to changing environmental conditions (Bolte et al. 2009). In this context, stand structure is closely related to many functions and services provided by forest ecosystems, such as timber production, wildlife conservation, biodiversity (McElhinny et al. 2005, Tews et al. 2004), microclimate (Ehbrecht et al. 2017), cycling of materials, and determining ecosystem sustainability and resilience (Mizunaga et al. 2010). All these services are directly or indirectly affected by the manipulation of stand structure and thus, by forest management (Mizunaga et al. 2010).

With regard to forest ecosystems, deforestation and unsustainable forms of forest exploitation are particularly responsible for losses in biodiversity and ecosystem functioning (Lindenmayer et al. 2000). Against this background, the important concept of promoting ecosystem functioning within the sustainable management of forest and woodland ecosystems has been discussed by national and international policies (Dieler et al. 2017, McElhinny et al. 2005, and Schütz 1999b). To fully appreciate the practical consequences of this new, multifunctional view on complex forest ecosystems, it is necessary to understand how complexity in forest ecosystems develops, what the ecological consequences are and how forest management could artificially alter it (Kuuluvainen 2009, O'Hara 2001, and Seidel 2018). Despite the great importance of forest structure, very little is known about its three-dimensional complexity and especially its natural development (Ehbrecht et al. 2017). Therefore, many studies deal with the structure of primary forests and their structural differences when compared to managed forests as well as deriving management implications aiming at the promotion of structural complexity (e.g. Commarmot et al. 2005, Hale et al. 1999, and Nagel et al. 2013). 


\subsection{Close-to-nature forestry based on knowledge about primary forests}

Research on structural dynamics and natural development of primary forests has been conducted for a long time (e.g. Korpel' 1995, Leibundgut 1959, 1978). These investigations can be helpful in understanding human impacts on forest ecosystems, and in evaluating and, if necessary, adapting forest management systems (Bauhus et al. 2009, Meyer 2005, Nagel et al. 2013, and Sabatini et al. 2018). Quantifying the structural complexity of completely unmanaged primary forests serves as an important reference for forest management, since management for complexity is increasingly appreciated as an effective method for maintaining a wide range of ecosystem functions and biodiversity in managed forest ecosystems (Puettmann et al. 2012). While the term "primary forest" often includes all forests having a higher degree of naturalness (e.g. Sabatini et al. 2018), in this study, it refers only to those forests that are actually essentially unmanaged until now (Buchwald 2005). However, one major challenge is that these primary forests of the temperate zone are very rarely found. Centuries of land use have resulted in only a few scattered primary forests remnants in Europe. These are mainly restricted to the east and southeast of Europe (e.g. Meyer 2005, Nagel et al. 2014, and Sabatini et al. 2018).

The two major processes that drive the natural development of forest ecosystems creating spatial and temporal heterogeneity are disturbances and successions (Kuuluvainen 2009, Nagel et al. 2014). These processes form a more or less clear repetitive cycle of forest structures in forest ecosystems (Fig. 1.1; Korpel' 1995, Kuuluvainen 2009, and Tabaku 1999), which are, without human intervention, controlled by small-scale (e.g. insects, fungi and age-related decay) or large-scale disturbances (e.g. wind and fire).

Traditional forest management aims at creating highly productive stands and at harvesting after rotation periods that are rather short when compared to periods of natural development (Bauhus et al. 2009). Thus, when comparing structural complexity in forests, age is of great importance. For example, the range of structural variation is grossly truncated in traditionally managed forests, especially because the decay phase is completely missing, which starts at higher ages than managed forests generally reach (Bauhus et al. 2009, Kuuluvainen 2009, and Lewis and Lindgren 2000). Traditional management systems are often in contradiction with the variable and complex characteristics of the disturbance-succession cycle observed in natural forests. The application of forest management practices to a forest stand could be seen as manipulation of this developmental cycle and as disturbance in an ecological sense, except that its 
consequences are mostly predictable (Boncina 2000, Lewis and Lindgren 2000). However, another aspect that cannot be predicted is the extent to which human influence can affect the stability and resilience of forests. For example, many studies conclude that traditional forest management could significantly reduce the stability of a stand by reducing its structural heterogeneity compared to natural references (e.g. Drever et al. 2006, Puettmann et al. 2015). In addition, Lindenmayer and Franklin (2002) confirmed that the intensity and the consequences of natural disturbances in artificially created stands, especially in intensively managed monocultures, differ significantly from those in natural forest ecosystems. This can actually be seen in several examples in Germany. Due to the dry summers of 2018, 2019, and numerous storms, many beech (Fagus sylvatica L.) or spruce (Picea abies L.) dominated forests are severely damaged, either directly through the drought or through pest damages caused by bark beetles such as Ips typographus in the case of spruce. It remains to be seen how these damaged ecosystems will develop in the future.

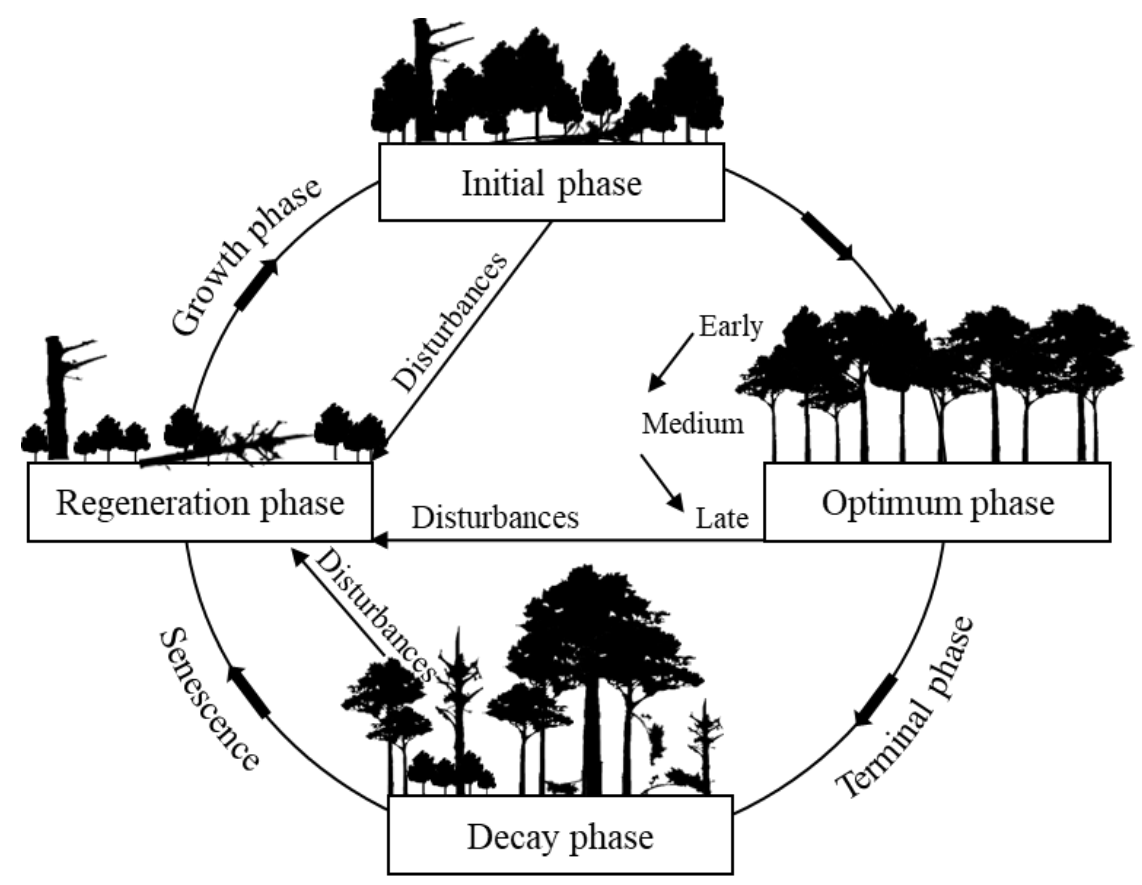

Figure 1.1: Simplified model of the developmental phases within the natural forest developmental cycle in beech-dominated forests modified after Begehold et al. (2015), Feldmann et al. (2018), and Král et al. (2010).

Integrating structural complexity into silvicultural systems is therefore believed to improve the resilience and adaptability of managed forests (Mizunaga et al. 2010, Parrott and Lange 2013, and Puettmann et al. 2012). One possibility is to use management approaches that are similar to natural disturbances in scope and frequency. Therefore, 
within the last decades, interest in management systems that emulate natural disturbances has increased (e.g. Bergeron et al. 1999, 2007, Perera et al. 2007, and Perera and Cui 2010). To provide information, studies in unmanaged primary forests or uneven-aged near-natural forests are necessary (Bauhus et al. 2009, Sabatini et al. 2018). In particular, studies on the response of stand structure in primary forests to natural disturbances produced useful insights and allowed conclusions on possible management implications (Kuuluvainen 2002, 2009, Mizunaga et al. 2010). In addition, structural comparisons between different management systems and primary forests can also help to better quantify the influence of management on forest structure. The deviation in stand structural complexity of a managed forest ecosystem from a primary forest as natural reference could then possibly also provide information on the stability and resilience to disturbances.

\subsection{Using TLS to quantify structural complexity}

Due to its complexity and three-dimensional character, forest structure is difficult to measure. For this reason, many methods, techniques and indices have been developed that describe different aspects of forest structure using different approaches (McElhinny et al. 2005, Pommerening 2002). Since the beginning of the $21^{\text {th }}$ century, further approaches based on Light Detecting and Ranging (LiDAR), also called laser scanning, have been developed in order to measure the geometry of objects in great detail. These approaches are also increasingly applied in forest sciences in order to capture forest structure as detailed as possible (e.g. Seidel et al. 2011) and has proven in recent years to be a suitable method to describe vegetation structures efficiently (Ehbrecht et al. 2016, 2017, Newnham et al. 2015, Palace et al. 2016, and Seidel et al. 2016b).

A laser scanner emits laser beams into its surrounding, which then are reflected by all adjacent objects and surfaces. The scanner again registers the reflected beams and calculates the distance between scanner and scanned object. The spatial information thus generated represents mathematical, three-dimensional point clouds in which Cartesian or spherical coordinates describe each point. Those LiDAR-sensors are mounted on airborne (ALS), stationary terrestrial (TLS) or mobile terrestrial (MLS) platforms. In this thesis the focus was on data from TLS as the laser scanning approach that provides the greatest level of detail on forest structure. A more detailed description of the scanners used here, the product details and scan settings can be found in the method descriptions of each of the following chapters (chap. 2.2, 3.2 and 4.2). 
TLS-systems have the potential to offer a three-dimensional representation of the scanned forest scene and thus allow for the objective and mathematical calculation of tree-based measurements, such as height, diameter at breast height $(1.3 \mathrm{~m})$ or stem density (Watt and Donoghue 2005). Furthermore, not only tree-related data but also so-called holistic measures can be derived from TLS data. These holistic measures can be further subdivided into single- and multi-perspective approaches (Ehbrecht 2017). The multiperspective approach is based on the combination of several scans into a multi-scan point cloud and is used when detailed information of the study area is of interest. The object of interest is scanned from more than one perspective in order to record it completely and three-dimensionally (Ehbrecht et al. 2016, Metz et al. 2013). During point cloud postprocessing, the scans were merged into one single three-dimensional point cloud using artificial reference points (e.g. checkerboard targets), which have to be set up in the forest scene before scanning. The arrangement of these artificial references is time-consuming and thus limits the possible applications, for example in forests with dense understory. The higher the number of scans and the smaller the distance between them in the multiscan point cloud, the more complete it is. However, the higher the level of detail, the larger the point cloud, which makes further point cloud processing and calculations more time-consuming and computationally demanding. For this reason, multi-scan point clouds are often converted into so called "voxel models" (voxel = "volumetric pixels) of different resolutions (Seidel 2018). Based on these voxel models, numerous holistic (not individual-related) measurements can be derived to describe forest structure: e.g. space filling (Juchheim et al. 2017), box-dimension (Seidel et al. 2019a), or canopy rugosity (Hardiman et al. 2011, 2013).

Single-scan approaches only rely on a single scan captured at a single position and do not need artificial reference points. This makes the approach much more time-efficient and allows recording larger areas and larger amounts of data in a short time. However, they also offer limited information as they measure the object under investigation from one side only. Therefore, some variables such as crown volume cannot be reliably determined using single scans. Other variables, such as the forests density or the vertical stand layering can be estimated from single scans, but lead to less reliable results than calculations based on multi-scans (Ehbrecht et al. 2016, Seidel et al. 2015b). This is due to the fact that vegetation elements cover each other in the direction of the emitted laser beams and thus, the surrounding cannot be completely captured. This shadowing-effect is called "occlusion" and causes the probability and accuracy of measuring an object to 
decrease with increasing distance from the scanner. (Ehbrecht et al. 2016, Zhao et al. 2015). Based on single-scans, there are several indices describing forest structure: e.g. the stand structural complexity-index (Ehbrecht et al. 2017), the understory complexity-index (Willim et al. 2019), effective number of layers (Ehbrecht et al. 2016), canopy openness (Woodgate et al. 2015), or foliage profiles (Zhao et al. 2015).

\subsection{Thesis objectives and hypotheses}

For this thesis, data was collected in four age-class forests, with two of them managed traditionally and two managed alternatively, two lately unmanaged National Parks, all located in Germany, and two completely unmanaged primary forests located in Slovakia and Ukraine. Furthermore, we captured data in six continuous cover forests of different sites and tree species mixtures as specific type of close-to-nature forest management. The study areas presented in Fig 1.2 serve as framework for all studies included here (Fig. 1.2; see more detailed descriptions of the study areas in chapters 2, 3 and 4).

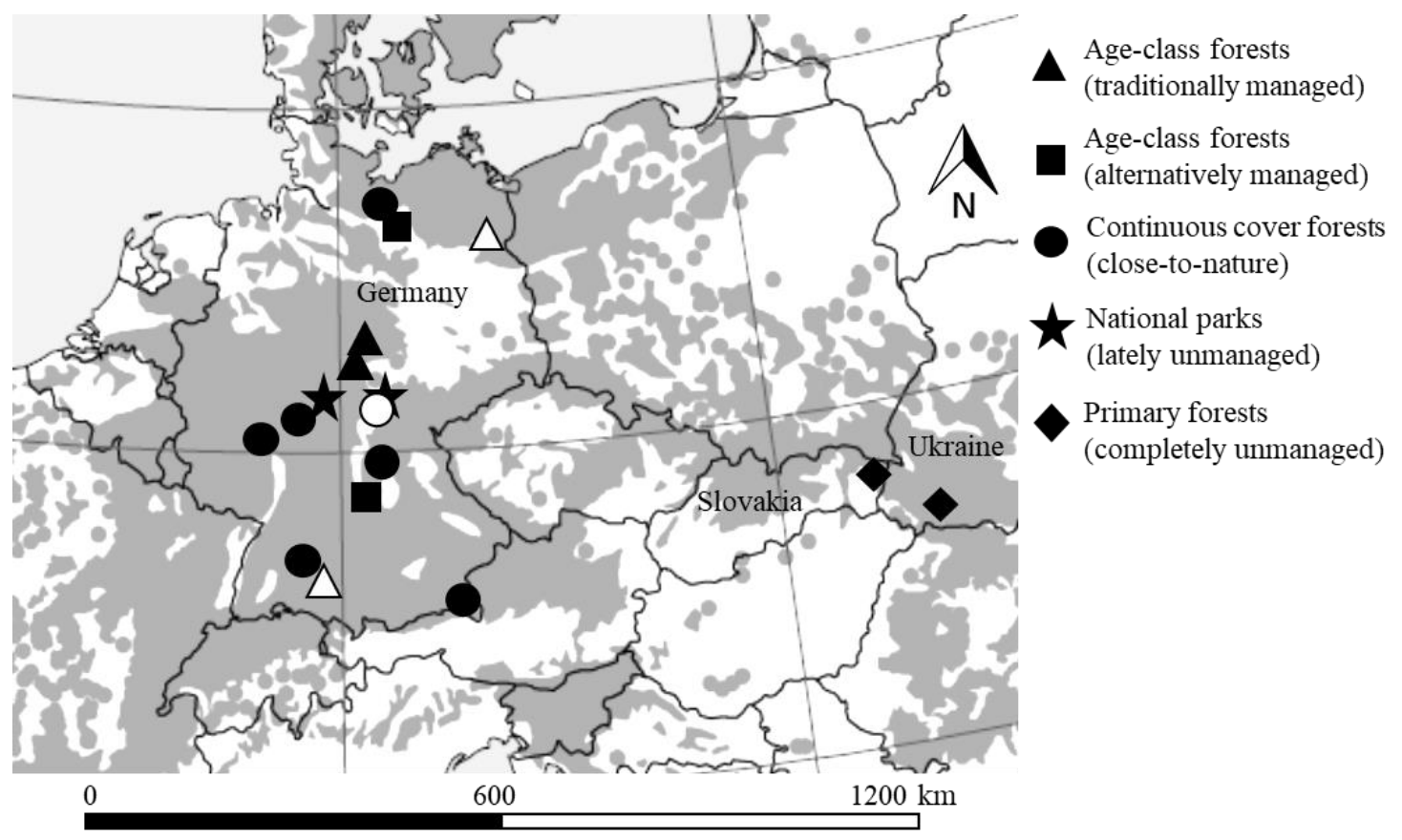

Figure 1.2: Geographic locations of the study areas located in Germany, Slovakia and Ukraine. Black symbols mark all study areas, where data was collected in the framework of this doctoral thesis. White symbols display reference stands including data, that was not collected by the candidate itself, but used for comparison (chapter 4). Grey areas mark the potential natural distribution of European beech without human influence according to EUFORGEN (2009). 
All study areas, except the continuous cover forests, consisted of pure stands or at least beech-dominated stands. European beech is of particular importance in German and central European forests (Czajkowski et al. 2006). The fact that beech would naturally dominate the German forests due to its enormous site and climatic amplitude (Fig. 1.2, e.g. Ellenberg 1996, Leuschner 1997) and its high competitive power, together with society's demand for higher naturalness in forests, has led to beech having a $15.4 \%$ stand area share with rising tendency in German forests nowadays (Thünen-Institute, BWI3). In order to select stands that are as homogeneous as possible and thus comparable, some criteria for plot selection were defined and strictly followed. All stands should consist of pure beech or at least beech-dominated mixtures with beech having a minimum basal area share of $66 \%$. This criterion does not affect the selection of continuous cover forests, as a mixture of tree species is a potential characteristic of this type of forest management. The managed forests should not have been disturbed by management interventions on this area for at least two years. Although there are large differences in terrain, the study sites were selected in areas as flat as possible. More details on plot selection and differences between the study areas can be found in chapter 2.2.1 and in chapter 4.2.1 for more information about the continuous cover forests selected here.

In each study area, 30 single-scans in a defined raster in a mature stand (at least 80$120+$ years) were conducted (Fig. 1.3a). In the traditionally and alternatively managed forests, 90 single-scans were taken additionally, 30 in each of three defined age classes: thickets with overstory trees (0-20 years), pole wood (20-40 years) and immature timber (40-80 years). All 600 single-scans were used to determine management effects on stand structure. Therefore, the stand structural complexity-index (Ehbrecht et al. 2017) was used to assess differences in structural complexity on stand level between the types of management investigated here. Since age also has significant effects on forest structure, the differently-aged stands were included into the analyses to evaluate influences of forest management on structural properties attributed to different developmental phases. Based on these results, recommendations for forest management could be derived, which could make it easier to increase structural complexity in managed forests.

Furthermore, we conducted four multi-scans in each of the eight mature stands (Fig. 1.3b). These multiplots were further differentiated into two plots without tree regeneration and two plots with already established regeneration of beech. To promote structural complexity in forests, it is necessary to control canopy cover and the different stand layers 
to regulate light availability and thus ensure successful regeneration and growth. Therefore, another analysis focused on the spatial top-down relationship between differently sized and shaped canopy gaps and resulting regeneration patches, wherefore we used the 16 multi-scans with established regeneration.

To evaluate and quantify structural properties and the degree of structural complexity of a specific form of close-to-nature-management, we used data out of the continuous cover forests (Fig. 1.2), where three multi-scans were completed respectively. The structural properties of these continuous cover forests were studied, quantified and compared to managed and unmanaged reference stands in order to assess their proximity to a previously defined "target state" of structural complexity.

(a) Single-scan approach

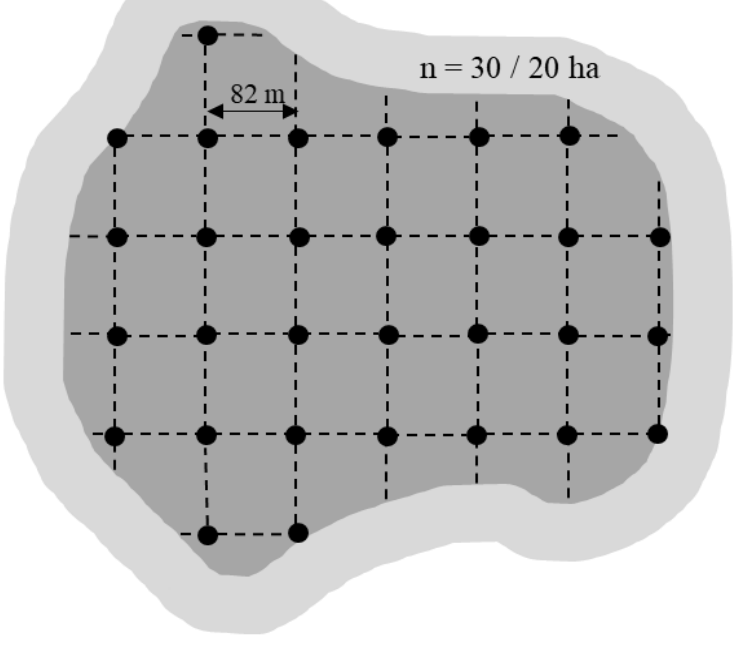

(b) Multi-scan approach

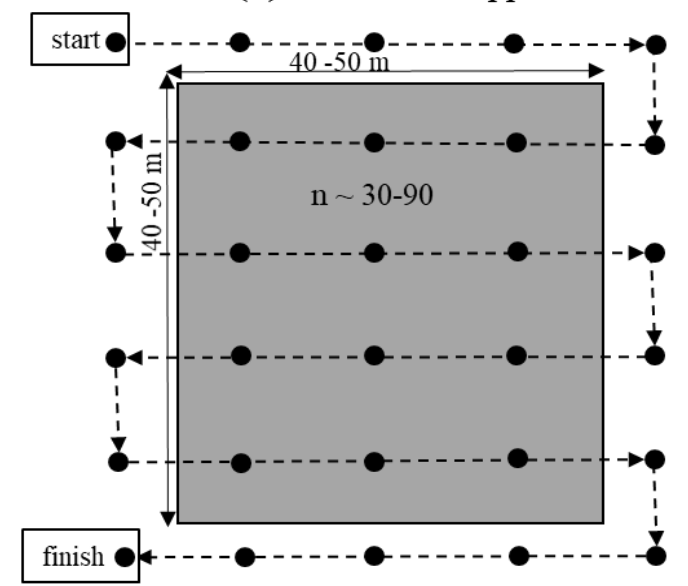

Figure 1.3: Sampling design for an exemplary plot. In the (a) Single-scan approach, 30 Single-scans were conducted within a forest plot of 20 ha each. Minimum distance between each individual single-scan was $82 \mathrm{~m}$. To reduce edge effects, a bufferzone of $20 \mathrm{~m}$ width was installed around the plot. In the (b) Multiscan approach, an area of $50 \times 50 \mathrm{~m}$ (or 40 x $40 \mathrm{~m}$ in chapter 4) was selected and systematically scanned with 30-90 single-scans depending on the forest's density.

The main objectives of this thesis were to quantify, whether and to which extent different types of forest management modify the structure and structural complexity in forests and to derive possible management implications to promote stand structural complexity in managed forests. It has been investigated many times that forestry affects the structure of a forest ecosystem (e.g. Dieler et al. 2017, Gustafsson et al. 2012), while different management strategies simplify or diversify structural attributes (Pretzsch 2009, Puettmann et al. 2012). Most of the studies focused on qualitative structural differences between managed forests and primary or near-natural forests (e.g. deadwood volume). In 
this study, based on TLS data, the comparison of structural differences in differently managed forests will be made on a quantitative level regarding three-dimensional forest characteristics. This doctoral thesis is a cumulative dissertation consisting of three independent but related papers. Two of these papers have been published (chapters 2, 3) and one is currently submitted (chapter 4).

The overall leading hypotheses were:

I. Forest management results in significant differences in forest structure and stand structural complexity along a gradient of management intensity in forests of European beech.

II. It is possible to identify a significant top-down-dependency between canopy gaps and understory complexity, as well as specific spatial regeneration patterns for European beech, which contributes to a better understanding of regeneration ecology.

III. Forest management decreases stand structural complexity compared to primary beech forests as natural reference. 


\subsection{References}

Abildtrup, J., Garcia, S., Stenger, A. (2013): The effect of forest land use on the cost of drinking water supply: A spatial econometric analysis. Ecological Economics, 92, 126-136.

Augustynczik, A.L.D., Gutsch, M., Basile, M., Suckow, F., Lasch, P., Yousefpour, R., Hanewinkel, M. (2020): Socially optimal forest management and biodiversity conservation in temperate forests under climate change. Ecological Economics, 169, 106504.

Bauhus, J., Puettmann, K., Messier, C. (2009): Silviculture for old-growth attributes. Forest Ecology and Management, 258, 525-537.

Beets, P.N., Oliver, G.R., Clinton, P.W. (2002): Soil carbon protection in podocarp/hardwood forest, and effects of conversion to pasture and exotic pine forest. Environmental pollution, 116, 63- 73 .

Begehold, H., Rzanny, M., Flase, M. (2015): Forest development phases as an integrating tool to describe habitat preferences of breeding birds in lowland beech forests. Journal of Ornithology, Vol. 156, Issue 1, 19-29.

Bergeron, Y., Harvey, B., Leduc, A., Gauthier, S. (1999): Forest management guidelines based on natural disturbance dynamics: stand- and forest-level considerations. The Forestry Chronicle, 75 (1), 49-54.

Bergeron, Y., Drapeau, P., Gauthier, S., Lecomte, N. (2007): Using knowledge of natural disturbances to support sustainable forest management in the northern clay belt. The Forestry Chronicle, 83 (3), 326-337.

Bolte, A., Ammer, C., Löf, M., Madsen, P., Nabuurs, G.J., Schall, P., ... \& Rock, J. (2009): Adaptive forest management in central Europe: climate change impacts, strategies and integrative concept. Scandinavian Journal of Forest Research, 24 (6), 473-482.

Bollmann, K., Braunisch, V. (2013): To integrate or to segregate: balancing commodity production and biodiversity conservation in European forests. Integrative approaches as an opportunity for the conservation of forest biodiversity. Joensuu EFI, 18-31.

Boncina, A. (2000): Comparison of structure and biodiversity in the Rajhenav virgin forest remnant and managed forest in the Dinaric region of Slovakia. Global Ecology \& Biogeography 9, 201-211.

Borrass, L., Kleinschmit, D., Winkel, G. (2016): The "German model" of integrative multifunctional forest management - Analysing the emergence and political evolution of a forest management concept. Forest Policy and Economics, 77, 16-23. 
Bottero, A., Garbarino, M., Dukic, V., Govedar, Z., Lingua, E., Nagel, T.A., Motta, R. (2011): Gap- phase dynamics in the old-growth forest of Lorn (Bosnia-Herzegovina). Silva Fennica, 45 (5), 875-887.

Buchwald, E. (2005): A hierarchical terminology for more or less natural forests in relation to sustainable management and biodiversity conservation. In: Third expert meeting on harmonizing forest-related definitions for use by various stakeholders. Proceedings. Food and Agriculture Organization of the United Nations. Rome. Pp. 17-19.

Canham, C.D., Denslow, J.S., Platt, W.J., Runkle, J.R., Spies, T.A., White, P.S. (1990): Light regimes beneath closed canopies and tree-falls gaps in temperate and tropical forests. Canadian Journal of Forest Research, 20 (5), 620-631.

Chazdon, R.L., Brancalion, P.H., Laestadius, L., Bennett-Curry, A., Buckingham, K., Kumar, C., ... \& Wilson, S.J. (2016): When is a forest a forest? Forest concepts and definitios in the era of forest and landscape restoration. Ambio, 45 (5), 538-550.

Commarmot, B., Bachofen, H., Bundziak, Y., Bürgi, A., Ramp, B., Shparyk, Y., ... \& Zingg, A. (2005): Structures of virgin and managed beech forests in Uholka (Ukraine) and Sihlwald (Switzerland): a comparative study. Forest Snow and Landscape Research, 79 (1/2), 4556.

Czajkowski, T., Kompa, T., Bolte, A. (2006): Zur Verbreitungsgrenze der Buche (Fagus sylvatica L.) im nordöstlichen Mitteleuropa. Forstarchiv, 77, 203-216.

Diaci, J. (editor) (2006): Nature-based forestry in Central Europe. Alternatives to industrial forestry and strict preservation. Biotechnical Faculty, Department of Forestry and Renewable Forest Resources, Ljubljana, Slovenia.

Diaci, J., Kerr, G., O’Hara, K. (2011): Twenty-first century forestry: integrating ecologically based, uneven-aged silviculture with increased demands on forests. Forestry, 84 (5), 463 465 .

Dieler, J., Uhl, E., Biber, P., Müller, J., Rötzer, T., Pretzsch, H. (2017): Effect of forest stand management on species composition, structural diversity, and productivity in the temperate zone of Europe. European Journal of Forest Research, 136, 739-766.

Drever, C.R., Peterson, G., Messier, C., Bergeron, Y., Flannigan, M. (2006): Can forest management based in natural disturbances maintain ecological resilience? Canadian Journal of Forest Research, 36 (9), 2285-2299.

Ehbrecht, M., Schall, P., Juchheim, J., Ammer, C., Seidel, D. (2016): Effective number of layers: A new measure for quantifying three-dimensional stand structure based on sampling with terrestrial LiDAR. Forest Ecology and Management, 380, 212-223. 
Ehbrecht, M. (2017): Quantifying three-dimensional stand structure and its relationship with forest management and microclimate in temperate ecosystems. eDiss, Georg-AugustUniversity Göttingen.

Ehbrecht, M., Schall, P., Ammer, C., \& Seidel, D. (2017): Quantifying stand structural complexity and its relationship with forest management, tree species diversity and microclimate. Agricultural and Forest Meteorology, 242, 1-9.

Ellenberg, H. (1996): Vegetation Mitteleuropas mit den Alpen. 5. Auflage, Ulmer, Stuttgart.

EUFORGEN (2009): Distribution map of Beech (Fagus sylvatica), www.euforgen.de.

Fahey, R.T., Alveshere, B.C., Burton, J.I., D’Amato, A.W., Dickinson, Y.L., Keeton, W.S., ... \& Saunders, M.R. (2018): Shifting conceptions of complexity in forest management and silviculture. Forest Ecology and Management, 421, 59-71.

Feldmann, E., Glatthorn, J., Hauck, M., Leuschner, C. (2018): A novel empirical approach for determining the extension of forest development stages in temperate old-growth forests. European Journal of Forest Research, 137, 321-335.

Franklin, J.F., Spies, T.A., van Pelt, R., Carey, A.B., Thornburgh, D.A., Berg, D.R., ... \& Bible, K. (2002): Disturbances and structural development of natural forest ecosystems with silvicultural implications, using Douglas-fir forests as an example. Forest Ecology and Management, 155 (1-3), 399-423.

Gadow, K.v., Zhang, C.Y., Wehenkel, C., Pommerening, A., Corral-Rivas, J., Korol, M., ... \& Zhao, X.H. (2012): Forest structure and diversity. Continuous Cover Forestry, Chapter 2, 29-83, Springer Netherlands.

Gustafsson, L., Baker, S.C., Bauhus, J., Beese, W.J., Brodie, A., Kouki, J., ... \& Neyland, M. (2012): Retention forestry to maintain multifunctional forests: a world perspective. BioScience 62 (7), 633-645.

Hale, C.M., Pastor, J., Rusterholz, K.A. (1999): Comparison of structural and compositional characteristics in old-growth and mature, managed hardwood forests of Minnesota, USA. Canadian Journal of Forest Research, 29, 1479-1489.

Hardiman, B.S., Bohrer, G., Gough, C.M., Vogel, C.S., Curtis, P.S. (2011): The role of canopy structural complexity in wood net primary production of a maturing northern deciduous forest. Ecology, 92 (9), 1818-1827.

Hardiman, B.S., Gough, C.M., Halperin, A., Hofmeister, K.L., Nave, L.E., Bohrer, G., Curtis, P.S. (2013): Maintaining high rates of carbon storage in old forests: A mechanism linking canopy structure to forest function. Forest Ecology and Management 298, 111-119. 
Hobi, M.L., Ginzler, C., Commarmot, B., Bugmann, H. (2015): Gap pattern of the largest primeval beech forest of Europe revealed by remote sensing. Ecosphere, 6 (5), 1-15.

Ishii, H. T., Tanabe, S. I., \& Hiura, T. (2004). Exploring the relationships among canopy structure, stand productivity, and biodiversity of temperate forest ecosystems. Forest Science, 50 (3), 342-355.

Juchheim, J., Ammer, C., Schall, P., Seidel, D. (2017): Canopy space filling rather than conventional measures of structural diversity explains productivity of beech stands. Forest Ecology and Management, 395, 19-26.

Korpel', S. (1995): Die Urwälder der Westkarpaten. Gustav Fischer Verlag.

Král, K., Vrska, T., Hort, L., Adam, D., Samonil, P. (2010): Developmental phases in a temperate natural spruce-fir-beech-forest: determination by a supervised classification method. European Journal of Forest Research, 129, 339-351.

Kuuluvainen, T. (2002): Natural variability of forests as a reference for restoring and managing biological diversity in boreal Fennoscandia. Silva Fennica, 36 (1), 97-125.

Kuuluvainen, T. (2009): Forest Management and Biodiversity conservation based on natural ecosystem dynamics in northern Europe: The complexity challenge. Ambio: A Journal of the Human Environment, 38 (6), 309-315.

Leibundgut, H. (1959): Über Zweck und Methodik der Struktur- und Zuwachsanalyse von Urwäldern. Schweiz. Zeitschrift für Forstwesen, 110 (3), 111-124.

Leibundgut, H. (1978): Über Zweck und Probleme der Urwaldforschung. Allgemeine Forstzeitschrift AFZ 33, 683.

Leuschner, C. (1997): Das Konzept der potentiellen natürlichen Vegetation (PNV): Schwachstellen und Entwicklungsperspektiven. Flora, 192, 379-391.

Levin, S.A. (2005): Self-organization and the emergence of complexity in ecological systems. BioScience, 55 (12), 1075-1079.

Lewis, K.J., Lindgren, B.S. (2000): A conceptual model of biotic disturbance ecology in the central interior of B.C.: How forest management can turn Dr. Jekyll into Mr. Hyde. The Forestry Chronicle, 76 (3), 433-443.

Lindenmayer, D.B., Margules, C.R., Botkin, D.B. (2000): Indicators of biodiversity for ecologically sustainable forest management. Conservation biology, 14 (4), 941-950.

Lindenmayer, D.B., Franklin, J.F. (2002): Conserving forest biodiversity: a comprehensive multiscaled approach. Island press.

MacArthur, R.H., MacArthur, J.W. (1961): On bird species diversity. Ecology, 42 (3), 594- 598. 
McElhinny, C., Gibbons, P., Brack, C., Bauhus, J. (2005): Forest and woodland stand structural complexity: Its definition and measurement. Forest Ecology and Management 218, 1-24.

Metz, J., Seidel, D., Schall, P., Scheffer, D., Schulze, E.D., Ammer, C. (2013): Crown modeling by terrestrial laser scanning as an approach to assess the effect of aboveground intra- and interspecific competition on tree growth. Forest Ecology and Management, 310, 275-288.

Meyer, P. (2005): Network of strict forest reserves as reference system for close to nature forestry in Lower Saxony, Germany. Forest Snow and Landscape Research, 79 (1/2), 33-44.

Mizunaga, H., Nagaike, T., Yoshida, T., Valkonen, S. (2010): Feasibility of silviculture for complex stand structures: designing stand structures for sustainability and multiple objects. Journal of Forest Research, 15, 1-2.

Nagel, T.A., Zenner, E.K., Brang, P. (2013): Research in old-growth forests and forest reserves: implications for integrated forest management. Integrative approaches as an opportunity for the conservation of forest biodiversity. Freiburg: European Forest Institute, 44-50.

Nagel, T.A., Svoboda, M., Kobal, M. (2014): Disturbance, life history traits, and dynamics in an old- growth landscape of southeastern Europe. Ecological Applications, 24 (4), 663-679.

Neill, A.R., Puettmann, K.J. (2013): Managing for adaptive capacity: Thinning improves food availability for wildlife and insect pollinators under climate change conditions. Canadian Journal of Forest Research, 43, 428-440.

Newnham, G.J., Armston, J.D., Calders, K., Disney, M.I., Lovell, J.L., Schaaf, C.B., Strahler, A.H., Danson, F.M. (2015): Terrestrial laser scanning for plot-scale forest measurement. Current Forestry Reports, 1 (4), 239-251.

O'Hara, K.L. (2001): The silviculture of transformation - a commentary. Forest Ecology and Management 151, 81-86.

O’Hara, K.L., Hasenauer, H., Kindermann, G. (2007): Sustainability in multi-aged stands: an analysis of long-term plenter systems. Forestry, 80 (2), 163-181.

Palace, M., Sullivan, F.B., Ducey, M., Herrick, C. (2016): Estimating tropical forest structure using a terrestrial lidar. PLoS One, 11 (4).

Parrot, L., Lange, H. (2013): An introduction to complexity science. In: Managing forests as complex adaptive systems, pp. 31-46. Routledge.

Perera, A.H., Buse, L.J., Weber, M.G. (eds.) (2007): Emulating natural forest landscape disturbances: concepts and applications. Columbia University Press. 
Perera, A.H., Cui, W. (2010): Emulating natural disturbances as a forest management goal: Lessons from fire regime simulations. Forest Ecology and Management, 259 (7), 13281337.

Podlaski, R., Sobala, T., Kocurek, M. (2019): Patterns of tree diameter distributions in managed and unmanaged Abies alba Mill. and Fagus sylvatica L. forest patches. Forest Ecology and Management 435, 97-105.

Pommerening, A. (2002): Approaches to quantifying forest structures. Forestry, 75 (3), 305- 324.

Pretzsch, H. (2009): Forest dynamics, growth, and yield. In: Forest dynamics, growth, and yield (pp. 1-39). Springer, Berlin, Heidelberg.

Puettmann, K.J., Coates, K.D., \& Messier, C. (2012): A critique of silviculture: managing for complexity. Island press.

Puettmann, K.J., Wilson, S.M., Baker, S.C., Donoso, P.J., Drössler, L., Amente, G., ... \& Putz, F.E. (2015): Silvicultural alternatives to conventional even-aged forest management what limits global adoption? Forest Ecosystems, 2 (1), 1-16.

Ribe, R.G. (2009): In- stand scenic beauty of variable retention harvests and mature forests in the US Pacific Northwest: The effects of basal area, density, retention pattern and down wood. Journal of Environmental Management, 91(1), 245-260.

Sabatini, F.M., Burrascano, S., Keeton, W.S., Levers, C., Lindner, M., Pötzschner, F., ... \& Debaive, N. (2018): Where are Europe's last primary forests? Diversity and Distributions, 24 (10), 1426-1439.

Schabel, H.G., Palmer, S.L. (1999): The Dauerwald: Its role in the restoration of natural forests. Journal of forestry, 97 (11), 20-25.

Schall, P., Gossner, M.M., Heinrichs, S., Fischer, M., Boch, S., Prati, D., ... \& Buscot, F. (2018a): The impact of even-aged and uneven-aged forest management on regional biodiversity of multiple taxa in European beech forests. Journal of applied Ecology, 55 (1), 267-278.

Schütz, J.-P. (1999b): Close-to-nature silviculture: is this concept compatible with species diversity? Forestry, 72 (4), 359-366.

Seidel, D., Beyer, F., Hertel, D., Fleck, S., Leuschner, C. (2011): 3D-laser scanning: A nondestructive method for studying above-ground biomass and growth of juvenile trees. Agriculural and Forest Meterology, 151 (10), 1305-1311.

Seidel, D., Hoffmann, N., Ehbrecht, M., Juchheim, J., Ammer, C. (2015b): How neighborhood affects tree diameter increment-new insights from terrestrial laser scanning and some methodical considerations. Forest Ecology and Management, 336, 119-128. 
Seidel, D., Ruziicka, K.J., Puettmann, K. (2016b): Canopy gaps affect the shape of Douglas-fir crowns in the western Cascades, Oregon. Forest Ecology and Management, 363, 31-38.

Seidel, D. (2018): A holistic approach to determine tree structural complexity based on laser scanning data and fractal analysis. Ecology and Evolution 2017, 1-7.

Seidel, D., Ehbrecht, M., Annighöfer, P., Ammer, C. (2019a): From tree to stand-level structural complexity - Which properties make a forest stand complex? Agricultural and Forest Meteorology, 278, 107699.

Seidel, D., Ehbrecht, M., Dorji, Y., Jambay, J., Ammer, C., Annighöfer, P. (2019b): Identifying architectural characteristics that determine tree structural complexity. Trees, 33 (3), 911919.

Tabaku, V. (1999): Struktur von Buchen-Urwäldern in Albanien im Vergleich mit deutschen Buchen- Naturwaldreservaten und -Wirtschaftswäldern. Dissertation. Cuvillier Verlag Göttingen.

Tews, J., Brose, U., Grimm, V., Tielbörger, K., Wichmann, M.C., Schwager, M., Jeltsch, F. (2004): Animal species diversity driven by habitat heterogeneity/diversity: the importance of keystone structures. Journal of Biogeography 31, 79-92.

Thompson, I.D., Mackey, B., McNulty, S., Mosseler, A. (2009): Forest Resilience, Biodiversity and Climate Change: A Synthesis of the Biodiversity/ resilience/stability relationship in Forest Ecosystems. Secretariat of the Convention on Biological Diversity. Technical Series Report no. 43.

Thünen-Institut, Dritte Bundeswaldinventur - Ergebnisdatenbank, https://bwi.info, Aufruf am 16.01.2020, Auftragskürzel: 77Z1JI_L235of_2012, Archivierungsdatum: 2014-6-10 16:7:59.927, Überschrift: Waldfläche (gemäß Standflächenanteil) [ha] nach Land und Baumartengruppe.

Watt, P.J., Donoghue, D.N.M. (2005): Measuring forest structure with terrestrial laser scanning. International Journal of remote sensing, 26 (7), 1437-1446.

Willim, K., Stiers, M., Annighöfer, P., Ammer, C., Ehbrecht, M., Kabal, M., Stillhard, J., Seidel, D. (2019): Assessing understory complexity in beech-dominated Forests (Fagus sylvatica L.)-from managed to primary forests. Sensors, 19, 1684.

Woodgate, W., Jones, S.D., Suarez, L., Hill, M.J., Armston, J.D., Wilkes, P., ... \& Mellor, A. (2015): Understanding the variability in ground-based methods for retrieving canopy openness, gap fraction, and leaf area index in diverse forest systems. Agricultural and Forest Meteorology, 205, 83-95. 
Yamamoto, S.I. (2000): Forest gap dynamics and tree regeneration. Journal of Forest Research, 5 (4), 223-229.

Zhao, K., Garcia, M., Liu, S., Guo, Q., Chen, G., Zhang, X., ... \& Meng, X. (2015): Terrestrial lidar remote sensing of forests: Maximum likelihood estimates of canopy profile, leaf area index, and leaf angle distribution. Agricultural and forest meteorology, 209, 100113. 


\section{Chapter 2}

\section{A quantitative comparison of the structural complexity of managed, lately unmanaged and primary European beech (Fagus sylvatica L.) forests}

This chapter is published as research article in Forest Ecology and Management, Volume 430, 21. August 2018, p. 357-365, Elsevier. 


\title{
A quantitative comparison of the structural complexity of managed, lately unmanaged and primary European beech
}

\section{(Fagus sylvatica L.) forests}

\author{
Melissa Stiers $^{1 *}$, Katharina Willim ${ }^{1}$, Dominik Seidel ${ }^{1}$, Martin Ehbrecht ${ }^{1}$, Myroslav \\ $\mathrm{Kabal}^{2}$, Christian Ammer $^{1}$ and Peter Annighöfer ${ }^{1}$
}

\footnotetext{
${ }^{1}$ University of Göttingen, Faculty of Forest Sciences, Silviculture and Forest Ecology of the temperate Zones, Büsgenweg 1, 37077 Göttingen, Germany

${ }^{2}$ Carpathian Biosphere Reserve, Laboratory of Forest Sciences, Vulytsya Krasne Pleso, 77, Rakhiv, Ukraine

* Shared authorship: These authors contributed equally to this work. Corresponding authors, email addresses: melissa.stiers@forst.uni-goettingen.de (M. Stiers), kwillim1@forst.uni-goettingen.de (K. Willim)
}
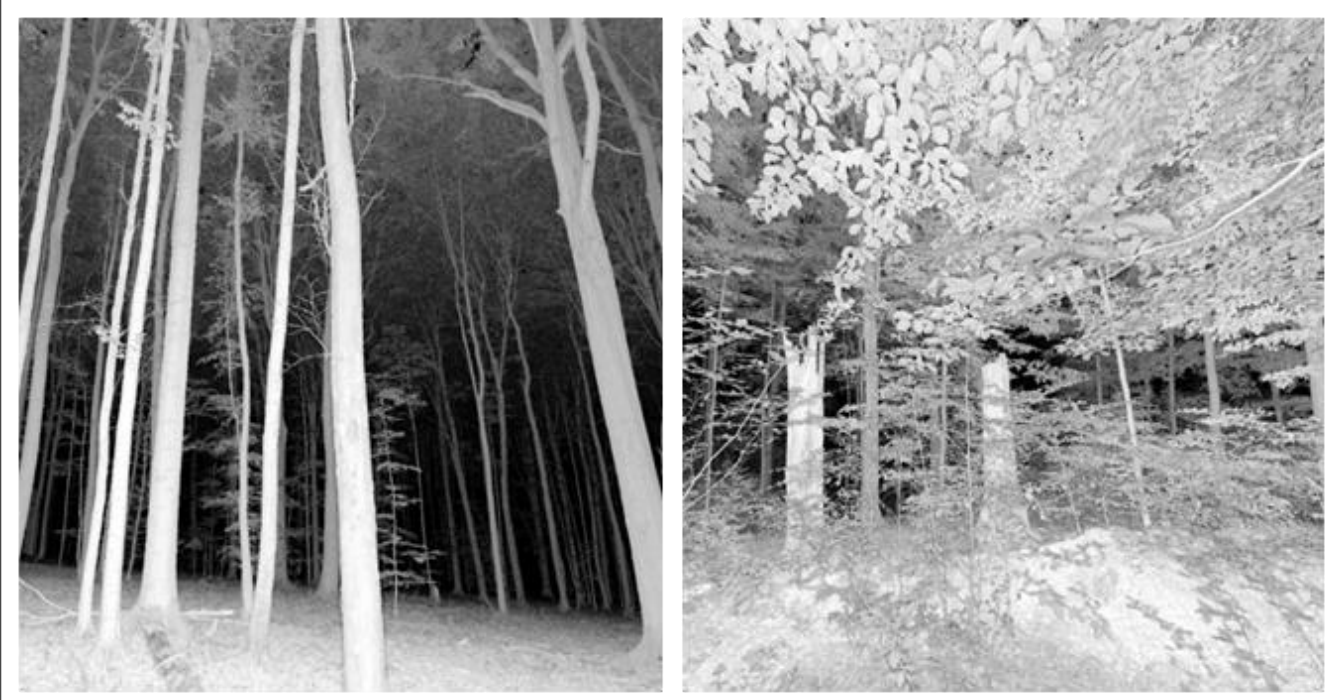

Katharina Willim and Melissa Stiers are first authors with equal rights. Together they have contributed significantly to the study concept and design, planned data acquisition, collected, and evaluated the data. Melissa Stiers was responsible for literature research, statistical data analysis, results and writing the manuscript. Peter Annighöfer and Dominik Seidel supervised the data analyses and together with Christian Ammer, Martin Ehbrecht, Katharina Willim and Myroslav Kabal they assisted, reviewed and edited the article draft. 


\begin{abstract}
The high structural heterogeneity of primary forests is assumed to positively affect various ecosystem traits and functions, e.g. biodiversity, resilience and adaptability. Against this background, old-growth forest structures are emulated in many managed forests. To properly emulate such structures, quantitative reference values are required, through which primary forests are characterized. In this study, we used the stand structural complexity index (SSCI), derived from terrestrial laser scanning (TLS), to characterize and compare the structures in European beech (Fagus sylvatica L.) dominated forests along a management gradient, ranging from differently managed stands, over formerly managed but now unmanaged stands to primary forests, which have never been managed. The study objective was to quantify and compare the structural complexity of these forests to give insight into possible reference points for an improved prospective handling of managed forests. The highest stand structural complexity was found in primary forests. While there were no significant structural differences between the managed forests, they were more complex in structure than formerly managed forests that have been set aside as National Parks now. The results also showed that structural complexity significantly differed between the investigated stand age classes. Next to primary forests, thickets growing below sheltering overstory trees in managed forests resulted in high structural complexity values. The findings suggest that specific silvicultural management practices can increase the structural complexity in beech forests. This study may facilitate a 'management for complexity' in silvicultural practice and might lead the way towards a more precise promotion of three-dimensional forest structures that are associated with specific forest functions as part of the stand management objectives.
\end{abstract}

Keywords: forest structure, management intensity, SSCI, virgin forest, developmental phases, terrestrial laser scanning, Carpathian Biosphere Reserve 


\subsection{Introduction}

An essential part of modern silviculture is emulating natural forest dynamics and structures as found in primary forests, while sustainably producing timber and maintaining the site productivity (Gustafsson et al. 2012, Nagel et al. 2013). In order to be able to imitate natural dynamics and structures in managed forests as much as possible, primary forests as reference systems need to be studied and their structural characteristics need to be quantified (Brang 2005, Nagel and Svoboda 2008, Feldmann et al. 2018a, Nagel et al. 2013). Under the current climate conditions, European beech (Fagus sylvatica L.) is one of the most important climax species in unmanaged forest ecosystems across Central Europe (Ellenberg and Leuschner 2010). However, only a few of such beech dominated primary forests could be preserved until today (Kucbel et al. 2012, Trotsiuk et al. 2012, Hobi et al. 2015, Glatthorn et al. 2017).

Korpel' (1995) and Tabaku (1999) described the natural dynamics of these primary forests by a developmental cycle, which mainly consists of three phases: the growth phase, the optimum phase and the decay phase. In the literature, other terms are used often: initial or establishment phase instead of growth phase, and terminal phase instead of decay phase (Feldmann et al. 2018b, Winter and Brambach 2011, Zenner et al. 2016). These phases can function as points of reference to characterize a specific forest structure, but they also tend to simplify the complexity of such structures. Natural disturbances can interrupt the developmental cycle at any time and reset the cycle. This can happen at small or quite large scales and depends on the type and intensity of the disturbance. Such disturbances are integrated parts of the complex natural forest development (Nagel et al. 2006, Feldmann et al. 2018a, Scherzinger 1996, Trotsiuk et al. 2012) and result in the high heterogeneity found in these primary forests.

One developmental phase usually not present in managed beech forests is a large-scale decay phase. In primary forests, European beech trees can reach an age of 400-500 years (Trotsiuk et al. 2012). In managed stands, the rotation period for beech usually lies around 120 to 140 years in Central Europe. Management hence prevents the beech trees from reaching their natural age limit (Bauhus et al. 2009, Boncina 2000, Scherzinger 1996). Consequently, many of the characteristics and attributes commonly associated with oldgrowth forests, like large numbers of dead or dying trees, veteran trees or high amounts of downed dead wood are mainly absent in managed stands (Bauhus et al. 2009, Meyer 
2005, Paffetti et al. 2012, Nagel et al. 2013). However, these attributes are significant structural elements affecting the three-dimensional forest appearance.

Structural dynamics in primary European beech forests are mainly driven by small-scale disturbances (Hobi et al. 2015, Nagel and Svoboda 2008, Feldmann et al. 2018a, Nagel et al. 2013, Trotsiuk et al. 2012). The main abiotic disturbance factors in European beech forests are storm events, which result in crown and tree damages or windthrow at different spatial scales (Jaloviar et al. 2017). Especially senescent or already damaged trees are susceptible towards wind. While larger canopy gaps either lead to an increased development or growth of lower canopy layers (vertical ingrowth), smaller canopy gaps are closed again through the horizontal canopy expansion of neighboring trees (Feldmann et al. 2018a, Pretzsch and Schütze 2005).

Despite recent findings reporting intermediate and also large-scale disturbances of several hectares in primary European beech forests (e.g. Nagel et al. 2006, Jaloviar et al. 2017, Feldmann et al. 2018a, Trotsiuk et al. 2012), the central European silvicultural approach for European beech still focusses mainly on mimicking small-scale disturbances by removing single trees or small tree groups, which either emulates self-thinning through competition or the phase of natural decay (Feldmann et al. 2018a). This approach aims at increasing the heterogeneity of forest structure and thereby promoting important ecosystem properties such as resistance and resilience (Knoke and Seifert 2008, Messier and Puettmann 2011, Pommerening 2002), as well as functions and services such as biodiversity (Brang 2005, Gustafsson et al. 2012, Pommerening 2002, but see Schall et al. 2018a for contrasting findings), productivity (Glatthorn et al. 2017, Juchheim et al. 2017), and microclimatic stability (Messier and Puettmann 2011, Ehbrecht et al. 2017) and other features of multi-functional forests (Gadow et al. 2012).

To successfully create such heterogeneous structures, they need to be measurable and reproducible in the first place. A conventional method to do this is measuring tree-based attributes, which are used to draw conclusions about the structure of the whole stand (Pommerening 2002, Schall et al. 2018b). Apart from conventional measures, terrestrial laser scanning (TLS) allows for a detailed quantification of stand structural complexity based on three-dimensional point clouds that reproduce the spatial arrangement of objects in a given forest scene with great detail. Such point clouds allow analyzing and comparing forest structures, e.g. across different management intensities and management types (Seidel et al. 2016, Ehbrecht et al. 2017). 
For European beech forests, it is unknown so far how the structure derived from threedimensional point clouds differs among differently aged forests, differently managed forests, lately unmanaged forests and primary forests. In this study, we applied a recently suggested TLS-based measure of structural complexity to investigate the structural properties of differently managed, lately unmanaged and completely unmanaged European beech forests in Germany, Slovakia and the Ukraine, including Europe's last primeval beech forests. We hypothesized that (i) structural complexity increases with decreasing management activity, and that (ii) significant differences in stand structure exist between different age classes, but high levels of structural complexity are not only limited to older stand ages.

\subsection{Materials and Methods}

\subsubsection{Study sites}

We selected European beech stands at 20 sites in eight study areas (Fig. 2.1 and Tab. 2.1). The study areas were regions with comparable climate conditions, which only show minor differences, and differently managed forests. Two management types, differing in harvest frequency and intensity were distinguished: traditional and alternative (see below). Within the study areas, we selected study sites of 20 ha in total size each but in some cases the area was comprised of smaller subplots (Tab. 2.1). All subplots within the sites were located in pure stands of European beech or in beech-dominated stands (at least $66 \%$ basal area represented by beech). Managed forests were not disturbed by silvicultural interventions for a minimum of two years. For managed forests, we predefined four different age classes to cover the range of developmental phases of the management system. The age classes were 0-20 years, $21-40$ years, 41-80 years and 81120 years. The youngest age class (0-20 years) includes thickets with shelterwood trees, the latter occur in different densities. Therefore, it must be taken into account that the determination of age refers not to the shelterwoods, but to the regeneration below. Generally, we tried to figure out the documented ages of the stands. However, this was only possible in the managed stands, where we have current data available. In the lately unmanaged National Parks, we have data about the age of the forest stands at that time when management was ceased, e.g. 30 years ago. Thus, we were able to calculate the current age, in which we extended the age to the year of data collection. Only in the primary forests, we had to rely on estimates from other studies. 


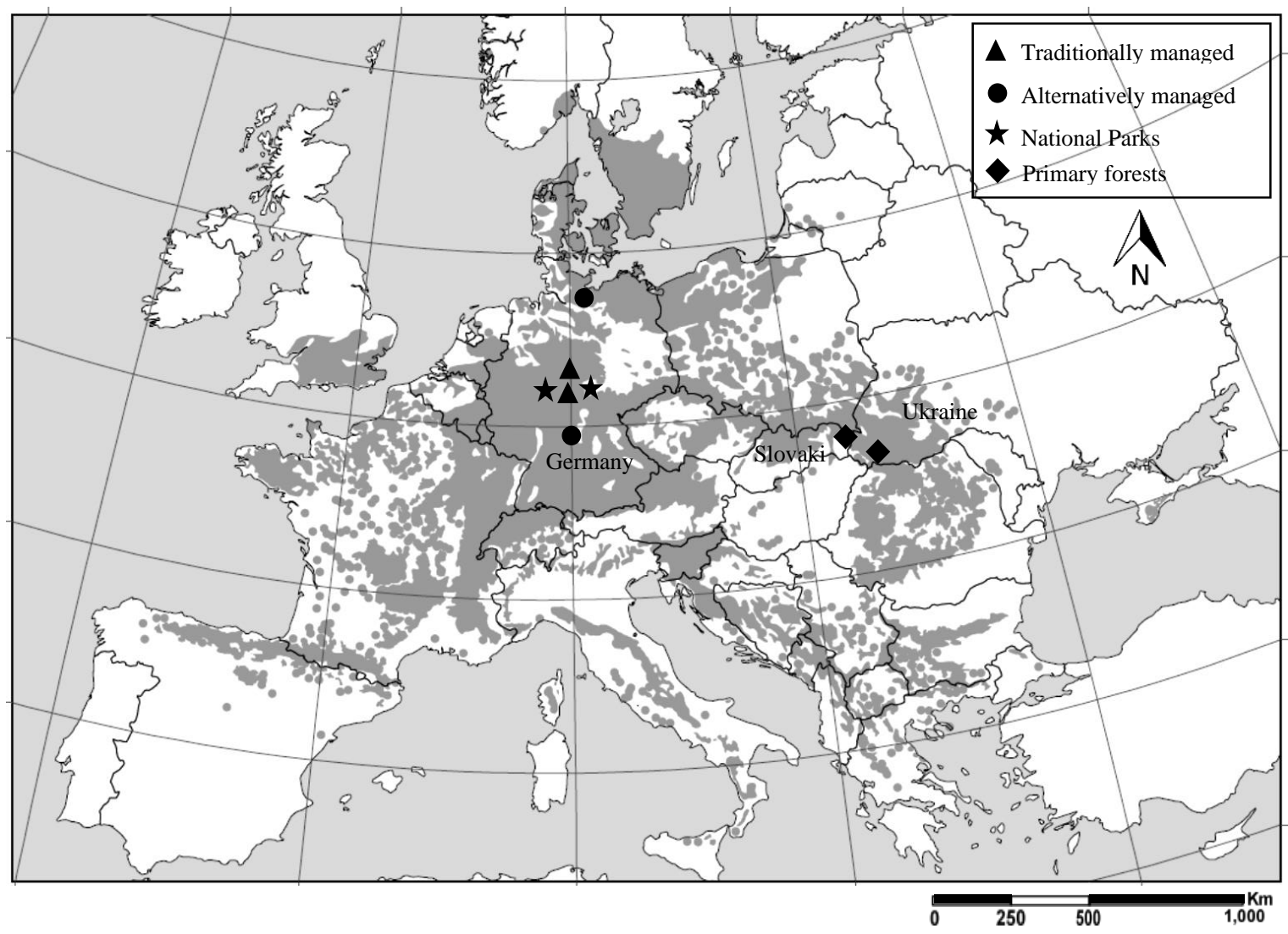

Figure 2.1: Distribution pattern (grey) of European beech (Fagus sylvatica L.) in Europe according to EUFORGEN (2009) and geographic locations of the eight study areas.

There were differences in terrain, ranging from coastal flat areas in Northern Germany (Lübeck) to mountainous areas in the Slovakian Carpathians (Rožok) and Western Ukraine (Uholka). The elevation ranged from approximately $40 \mathrm{~m}$ a.s.1. in Lübeck to 840 $\mathrm{m}$ a.s.l. in Uholka. Annual precipitation and mean annual temperature were comparable between the different sites (comp. Tab. 2.1). Only in Uholka, the annual precipitation is significantly higher than at all the other sites. Aside of these variations, the major distinction between the study sites is the type of management, thus, the human impact.

As traditionally managed forests comprising all age classes, we identified beech stands in the forest districts of Hannoversch Münden and Reinhausen in Lower Saxony, Germany. Beech forests with an alternative management approach were identified in Lübeck, Schleswig-Holstein and Ebrach, Bavaria, both Germany. The main differences between traditional and alternative forest management are the harvesting frequencies and intensities, both of which are lower in the alternative management type. Furthermore, one of the management goals in Lübeck and Ebrach (alternative management sites) is to constantly maintain a particularly high amount of coarse woody debris. In Ebrach, specific types of dead wood, such as snag trees with a diameter at breast height over 
$50 \mathrm{~cm}$, are promoted especially to strengthen the protective function of forests. In Lübeck, the management focus lies on a constantly increasing growing stock beyond traditional yield table values by ceasing silvicultural activities within stand ages of 30 to 80 years before initiating final harvests, which are also less intense when compared to the traditional regime. The traditionally managed forests (Hannoversch Münden and Reinhausen) are characterized by a more yield-orientated management with thinning cycles of around 5-years. Here, management is orientated on the "Guidelines of beech forest management in Lower Saxony, Germany" (NLF) with elimination of two to three competitors per target tree during growth and optimum phase and removal of all trees lager than $65 \mathrm{~cm}$ in diameter at breast height during final harvesting. In contrast, alternative management in our definition does not follow these guidelines but the period of final harvesting is extended, trees are growing beyond target diameters in large numbers and competitors are removed less intensively.

As lately unmanaged beech forests we chose two German National Parks, the "Kellerwald-Edersee National Park" in Hessia and the "Hainich National Park" in Thuringia. Both forests had formerly also been managed traditionally but have now been unmanaged since two to three decades, respectively. The stands at the study sites within the Hainich National Park had an average age of 183 years. In Kellerwald-Edersee, the stand ages varied between 174 and 194 years. With an average age of around 180 years for the majority of the mature trees, both National Parks were considered to be in the developmental stage of mature timber. This age was used to compare the age classes of the different forests.

As primary forests, which have never experienced human management, we chose two forests located outside of Germany, because there are no primary forests left in Germany. One beech dominated primary forest was located in Slovakia, were we collected data in Rožok, a strictly protected reserve 67.15 ha in size, located close to the Ukraine border. The 20 ha study site was on a north-northwest facing slope with an inclination of up to $20^{\circ}$. The other beech dominated primary forest was located in Ukraine. We collected our data in Uholka. The 20 ha plot we chose belonged to 8.800 ha of primary forest in the Uholka-Shyrokoluzhansky area, which are part of the Carpathian Biosphere Reserve (cbr.nature.org.ua). The site was southeast exposed with slope inclinations of up to $25^{\circ}$. Next to beech, the primary forests were additionally comprised of maple (Acer pseudoplatanus and Acer platanoides) and ash (Fraxinus excelsior) trees in Uholka and 
maple and wild cherry (Prunus sp.) in Rožok (Korpel' 1995, Commarmot et al. 2005). The average age of mature trees was 180 to 230 years in Rožok (Korpel' 1995). In Uholka, the mean age of dominant trees was estimated to be 350 years (Trotsiuk et al. 2012). We assumed a conservative mean age of about 220 years for most of the mature trees in Rožok and about 350 years in Uholka for the age class comparisons.

\subsubsection{Sampling design and data collection (terrestrial laser scanning)}

To collect the data on the 30 sample points at each study site, we applied a systematic sampling grid (North-South, West-East oriented) with a grid size of $82 \mathrm{~m}$ to assure avoiding intersections within the sampling points and resulting data. Sample points with a distance of less than $20 \mathrm{~m}$ to the forest edges, path ways, roads and neighboring forest stands with different properties (in the managed stands) were not considered. The total number of sample points was 120 in each of the four managed forests, 60 in the lately unmanaged National Park forests and 60 in the primary forests, resulting in a total of 600 scans (see Tab. 2.1). At each sample point, a single terrestrial laser scan was conducted. For each scan, the Faro Focus 3D 120 laser scanner (Faro Technologies Inc., Lake Mary, USA) was mounted on a tripod at breast height $(1.30 \mathrm{~m})$. Scan settings were set to cover a field of view of $360^{\circ}$ in horizontal and $300^{\circ}$ in vertical direction with an angular resolution of 10.240 points per $360^{\circ}$. Using phase-difference technology the Focus 3D emits laser beams into the forest scene and detects those beams reflected from surrounding trees or other vegetation elements with a maximum distance of $120 \mathrm{~m}$. All scans were conducted in the vegetation period 2017 (between May and September), with all species being densely foliaged.

\subsubsection{Data analysis}

To quantify the forest structure of the 600 terrestrial laser scans we used the "stand structural complexity index" (SSCI) developed by Ehbrecht et al. (2017) using Mathematica software (Wolfram Research, Champaign, USA). The SSCI is a "holistic" approach to quantify stand structural complexity based on the overall distribution pattern of all plant elements in the scanned scene. The index describes the relationship between the perimeters and areas of 1280 polygons that describe cross-sections through the forest scene, which are obtained from the scanner's perspective. These cross-sectional polygons mathematically describe the fractal dimension and may therefore represent the stand structural complexity at the scanned position (Ehbrecht et al. 2017). Figure 2.2 illustrates 
the range of possible values SSCI can reach. Please consult Ehbrecht et al. (2017) for more details.
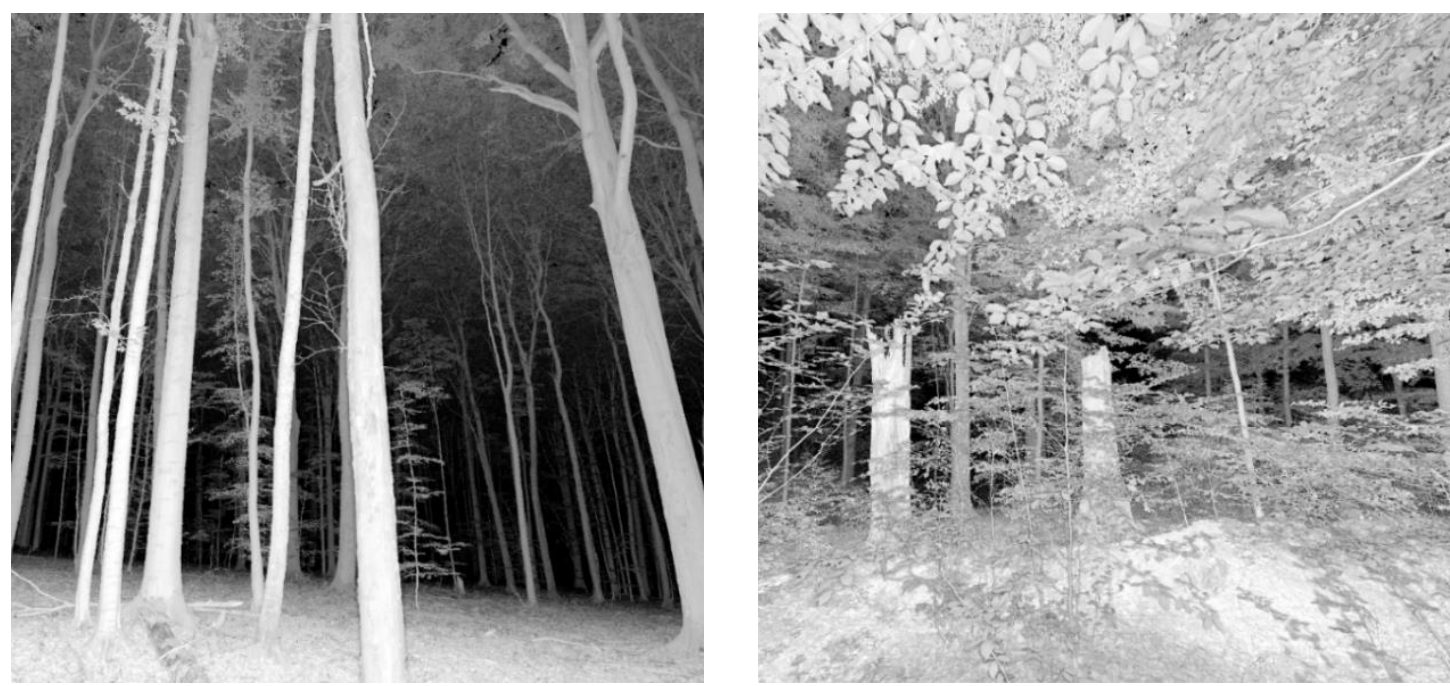

Figure 2.2: Examples of stands with low (left) and high (right) stand structural complexity. Left: SingleScan in the National Park "Hainich", SSCI: 3.15 and right: Single-Scan in the primary forest Uholka, SSCI: 12.22 .

We tested for differences in SSCI between sites by using the non-parametric KruskalWallis-test, because parametric assumptions like normal distribution and homogeneity of variance were not met (Shapiro-Wilk-test for normality; Levene Test for homogeneity of variance). For Posthoc-comparisons between the variables "management type" and "age class", we used the Wilcoxon rank sum test with the Bonferroni p-value adjustment method. In order to enable reliable statements about the correlations between the regarded variables, we used Spearman's rank correlation "rho".

We analyzed the relationships between the SSCI as dependent (y) and age as independent (x) variable, by applying a non-linear Generalized Additive Model (GAM) (Hastie and Tibshirani 1990, Wood 2006). Such models allow an unbiased detection of trends in the data because the relationship between dependent and independent variable does not need to be specified in advance (Otto et al. 2014). To avoid model over-fitting the effective degrees of freedom (EDF) were limited to a maximum of four (number of knots $=5$ ). However, the amount of smoothing was chosen automatically through generalized crossvalidation (Cianelli et al. 2004). The identity-link function was used and the data family was set to Gaussian type (Wood 2011). Model evaluation was conducted by interpreting the EDF value. Values clearly above one indicate non-linearity, which was the case in our study. For all statistical tests, we used a significance level of $\mathrm{p}<0.05$. The statistical analyses were conducted with R (R Core Team 2017). 
Chapter 2

Table 2.1: Detailed information about the climatic and geographic conditions of the study sites. The coordinates were taken at the center of each subplot.

\begin{tabular}{|c|c|c|c|c|c|c|c|c|c|}
\hline Country & Management type & Study area & $\begin{array}{c}\text { Mean } \\
\text { temperature } \\
\left({ }^{\circ} \mathrm{C}\right)\end{array}$ & 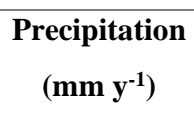 & $\begin{array}{c}\text { Elevation } \\
\text { (m a.s.l.) }\end{array}$ & $\begin{array}{c}\text { Age class } \\
\text { (years) }\end{array}$ & $\begin{array}{c}\text { Subplot } \\
\text { No. }\end{array}$ & No. of scans & Geolocation \\
\hline \multirow[t]{23}{*}{ Germany } & \multirow{17}{*}{$\begin{array}{l}\text { Traditionally } \\
\text { managed }\end{array}$} & \multirow{9}{*}{$\begin{array}{l}\text { Hann. } \\
\text { Münden }\end{array}$} & \multirow[t]{9}{*}{$6.5-7.5$} & \multirow[t]{9}{*}{$750-1050$} & \multirow[t]{9}{*}{$270-410$} & \multirow[t]{2}{*}{$0-20$} & $\mathrm{hm} 1$ & 17 & $51^{\circ} 29^{\prime} 34.10^{\prime \prime} \mathrm{N}, 9^{\circ} 39^{\prime} 38.64 " \mathrm{E}$ \\
\hline & & & & & & & $\mathrm{hm} 2$ & 13 & $51^{\circ} 29^{\prime} 38.73 " \mathrm{~N}, 9^{\circ} 39^{\prime} 47.78^{\prime \prime} \mathrm{E}$ \\
\hline & & & & & & \multirow[t]{3}{*}{$21-40$} & $\mathrm{hm} 3$ & 15 & $51^{\circ} 19^{\prime} 40.23^{\prime \prime N}, 9^{\circ} 44^{\prime} 9.74 " \mathrm{E}$ \\
\hline & & & & & & & $\mathrm{hm} 4$ & 7 & $51^{\circ} 20^{\prime} 17.88^{\prime \prime} \mathrm{N}, 9^{\circ} 43^{\prime} 15.39^{\prime \prime} \mathrm{E}$ \\
\hline & & & & & & & $\mathrm{hm5}$ & 8 & $51^{\circ} 20^{\prime} 15.34 " \mathrm{~N}, 9^{\circ} 41^{\prime} 17.51^{\prime \prime} \mathrm{E}$ \\
\hline & & & & & & \multirow[t]{2}{*}{$41-80$} & hm6 & 12 & $51^{\circ} 25^{\prime} 6.11^{\prime \prime N}, 9^{\circ} 47^{\prime} 43.86 " \mathrm{E}$ \\
\hline & & & & & & & $\mathrm{hm} 7$ & 18 & $51^{\circ} 25^{\prime} 6.49^{\prime \prime} \mathrm{N}, 9^{\circ} 47^{\prime} 23.53^{\prime \prime} \mathrm{E}$ \\
\hline & & & & & & \multirow[t]{2}{*}{$81-120$} & $\mathrm{hm} 8$ & 17 & $51^{\circ} 25^{\prime} 58.21^{\prime \prime N}, 9^{\circ} 47^{\prime} 6.39 " \mathrm{E}$ \\
\hline & & & & & & & $\mathrm{hm} 9$ & 13 & $51^{\circ} 26^{\prime} 12.68^{\prime \prime} \mathrm{N}, 9^{\circ} 47^{\prime} 20.07 " \mathrm{E}$ \\
\hline & & \multirow[t]{8}{*}{ Reinhausen } & \multirow[t]{8}{*}{8} & \multirow[t]{8}{*}{740} & \multirow[t]{8}{*}{$190-310$} & \multirow[t]{2}{*}{$0-20$} & rh1 & 22 & $51^{\circ} 37^{\prime} 5.94 " \mathrm{~N}, 10^{\circ} 5^{\prime} 48.86 " \mathrm{E}$ \\
\hline & & & & & & & rh2 & 8 & $51^{\circ} 35^{\prime} 45.48 " \mathrm{~N}, 10^{\circ} 4^{\prime} 45.13^{\prime \prime} \mathrm{E}$ \\
\hline & & & & & & \multirow[t]{2}{*}{$21-40$} & rh3 & 22 & $51^{\circ} 38^{\prime} 16.12^{\prime \prime} \mathrm{N}, 10^{\circ} 3^{\prime} 9.87^{\prime \prime E}$ \\
\hline & & & & & & & rh4 & 8 & $51^{\circ} 38^{\prime} 32.64 " \mathrm{~N}, 10^{\circ} 3^{\prime} 16.38^{\prime \prime} \mathrm{E}$ \\
\hline & & & & & & \multirow[t]{3}{*}{$41-80$} & rh5 & 9 & $51^{\circ} 38^{\prime} 11.90 " \mathrm{~N}, 10^{\circ} 3{ }^{\prime} 26.46 " \mathrm{E}$ \\
\hline & & & & & & & rh6 & 4 & $51^{\circ} 38^{\prime} 16.56 " \mathrm{~N}, 10^{\circ} 2^{\prime} 57.20^{\prime \prime} \mathrm{E}$ \\
\hline & & & & & & & rh7 & 17 & $51^{\circ} 37^{\prime} 39.44^{\prime \prime} \mathrm{N}, 10^{\circ} 2^{\prime} 57.54^{\prime \prime} \mathrm{E}$ \\
\hline & & & & & & $81-120$ & rh8 & 30 & $51^{\circ} 366^{\prime} 57.11^{\prime \prime N}, 10^{\circ} 5^{\prime} 0.93 " \mathrm{E}$ \\
\hline & \multirow{6}{*}{$\begin{array}{l}\text { Alternatively } \\
\text { managed }\end{array}$} & \multirow[t]{6}{*}{ Ebrach } & \multirow[t]{6}{*}{$7-8$} & \multirow[t]{6}{*}{850} & \multirow[t]{6}{*}{$320-480$} & \multirow[t]{2}{*}{$0-20$} & eb1 & 11 & $49^{\circ} 50^{\prime} 18.64 " \mathrm{~N}, 10^{\circ} 32^{\prime} 36.39^{\prime \prime} \mathrm{E}$ \\
\hline & & & & & & & eb2 & 19 & $49^{\circ} 55^{\prime} 43.87 " \mathrm{~N}, 10^{\circ} 30^{\prime} 29.33^{\prime \prime} \mathrm{E}$ \\
\hline & & & & & & \multirow[t]{2}{*}{$21-40$} & eb3 & 12 & $49^{\circ} 52^{\prime} 51.38^{\prime \prime} \mathrm{N}, 10^{\circ} 26^{\prime} 47.32 " \mathrm{E}$ \\
\hline & & & & & & & eb4 & 18 & $49^{\circ} 51^{\prime} 6.40 " \mathrm{~N}, 10^{\circ} 27^{\prime} 26.50^{\prime \prime} \mathrm{E}$ \\
\hline & & & & & & \multirow[t]{2}{*}{$41-80$} & eb5 & 19 & $49^{\circ} 52^{\prime} 42.87 " \mathrm{~N}, 10^{\circ} 26^{\prime} 41.90^{\prime \prime} \mathrm{E}$ \\
\hline & & & & & & & eb6 & 11 & $49^{\circ} 55^{\prime} 24.31 " \mathrm{~N}, 10^{\circ} 29^{\prime} 50.98 " \mathrm{E}$ \\
\hline
\end{tabular}


Chapter 2

\begin{tabular}{|c|c|c|c|c|c|c|c|c|c|}
\hline & & & & & & $81-120$ & eb7 & 30 & $49^{\circ} 51^{\prime} 26.97 " \mathrm{~N}, 10^{\circ} 29^{\prime} 4.83 " \mathrm{E}$ \\
\hline & & \multirow[t]{8}{*}{ Lübeck } & \multirow[t]{8}{*}{$8-8.5$} & \multirow[t]{8}{*}{$625-725$} & \multirow[t]{8}{*}{$40-90$} & $0-20$ & lb1 & 30 & $53^{\circ} 41^{\prime} 15.96 " \mathrm{~N}, 10^{\circ} 41^{\prime} 50.21^{\prime \prime E}$ \\
\hline & & & & & & $21-40$ & $\mathrm{lb} 2$ & 8 & $53^{\circ} 41^{\prime} 25.73^{\prime \prime} \mathrm{N}, 10^{\circ} 41^{\prime} 1.57^{\prime \prime E}$ \\
\hline & & & & & & & lb3 & 22 & $53^{\circ} 41^{\prime} 9.81^{\prime \prime} \mathrm{N}, 10^{\circ} 41^{\prime} 6.59^{\prime \prime} \mathrm{E}$ \\
\hline & & & & & & $41-80$ & lb4 & 13 & $53^{\circ} 41^{\prime} 29.21^{\prime \prime} \mathrm{N}, 10^{\circ} 41^{\prime} 50.97 " \mathrm{E}$ \\
\hline & & & & & & & lb5 & 11 & $53^{\circ} 43^{\prime} 9.00^{\prime \prime} \mathrm{N}, 10^{\circ} 40^{\prime} 24.01 " \mathrm{E}$ \\
\hline & & & & & & & lb6 & 6 & $53^{\circ} 42^{\prime} 51.97 " \mathrm{~N}, 10^{\circ} 40^{\prime} 2.31 " \mathrm{E}$ \\
\hline & & & & & & $81-120$ & $1 \mathrm{~b} 7$ & 25 & $53^{\circ} 41^{\prime} 25.92^{\prime \prime} \mathrm{N}, 10^{\circ} 41^{\prime} 30.45^{\prime \prime E}$ \\
\hline & & & & & & & lb8 & 5 & $53^{\circ} 42^{\prime} 28.60^{\prime \prime} \mathrm{N}, 10^{\circ} 39^{\prime} 37.24 " \mathrm{E}$ \\
\hline & \multirow{3}{*}{$\begin{array}{l}\text { National Park } \\
\text { (lately unmanaged) }\end{array}$} & Kellerwald & $6-8$ & $600-800$ & $540-635$ & $\sim 180$ & kw1 & 11 & $51^{\circ} 7^{\prime} 47.88^{\prime \prime N}, 8^{\circ} 58^{\prime} 41.62^{\prime \prime E}$ \\
\hline & & & & & & & kw2 & 19 & $51^{\circ} 7{ }^{\prime} 33.42^{\prime \prime N}, 8^{\circ} 57^{\prime} 48.06 " \mathrm{E}$ \\
\hline & & Hainich & $7-8$ & $600-800$ & $330-380$ & $\sim 180$ & ha1 & 30 & $51^{\circ} 6{ }^{\prime} 4.92^{\prime \prime N}, 10^{\circ} 27^{\prime} 32.11^{\prime \prime E}$ \\
\hline Slovakia & \multirow{2}{*}{$\begin{array}{l}\text { Primary forest } \\
\text { (unmanaged) }\end{array}$} & Rožok & $6-7$ & 780 & $580-745$ & $\sim 220$ & Rz1 & 30 & $48^{\circ} 58^{\prime} 36.67^{\prime \prime N}, 22^{\circ} 27^{\prime} 40.24 " \mathrm{E}$ \\
\hline Ukraine & & Uholka & 7 & 1407 & $700-840$ & $\sim 350$ & Uh1 & 30 & $48^{\circ} 16^{\prime} 10.08^{\prime \prime N}, 23^{\circ} 37^{\prime} 16.31^{\prime \prime E}$ \\
\hline
\end{tabular}




\subsection{Results}

The SSCI was found to be highest in the primary forests. It was significantly higher there than in the managed forests and the National Parks ( $\mathrm{p}<0.001$, Fig. 2.3). No significant difference in SSCI was found between traditionally and alternatively managed forests. Therefore, the two different management systems were pooled and are categorized as 'managed forests' from here on. Interestingly, the SSCI was significantly higher in the managed forests when compared to the National Parks

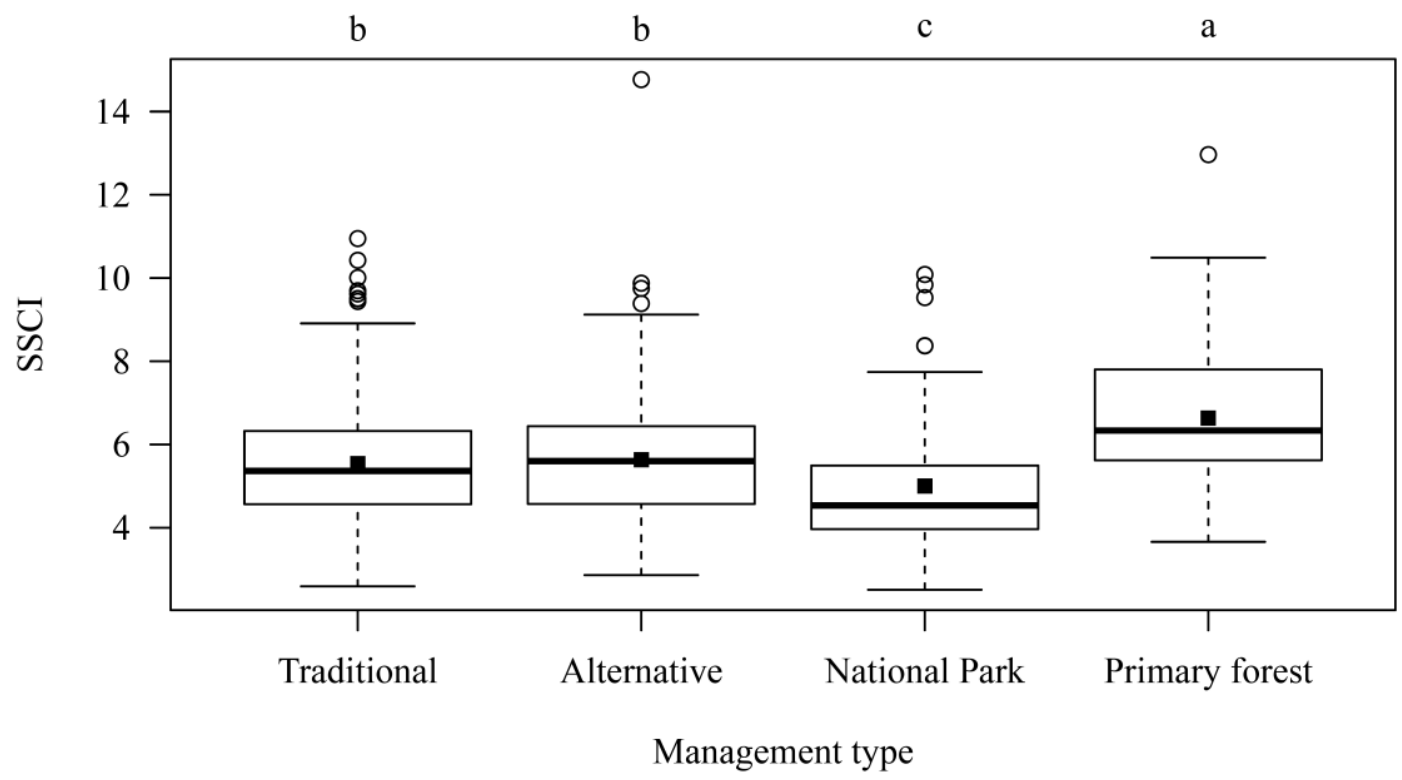

Figure 2.3: Box-Whisker plots of stand structural complexity index (SSCI) over different management types and along a management gradient (from managed, lately unmanaged, and always unmanaged). Black horizontal lines indicate the median, black points mark the mean values. ( $n=240$ for "Traditional" and “Alternative", $n=60$ for "National Park" and "Primary forest"). Different lower case letters indicate significant differences among the management types classes at the level of $p<0.05$.

Significant differences in SSCI were also found between different age classes (Fig. 2.4). The three highest mean SSCI-values were found for the age classes 0-20 years, 220 years and $\sim 350$ years. The highest structural complexity values were found for the age class $\sim 350$ years, observed in the primary forest Uholka. There was no significant difference between the SSCI in Rožok ( 220 years) and thickets with shelterwood trees (0-20 years). Lowest SSCI values were observed in the age class $\sim 180$ years that were found in the National Parks. The SSCI was not significantly different in the three age classes ranging from 21 to 120 years. Overall, we found a non-linear trend of a constantly decreasing SSCI up to an age of about 180 years and then an increasing structural complexity in the older stands (Fig. 2.5). 


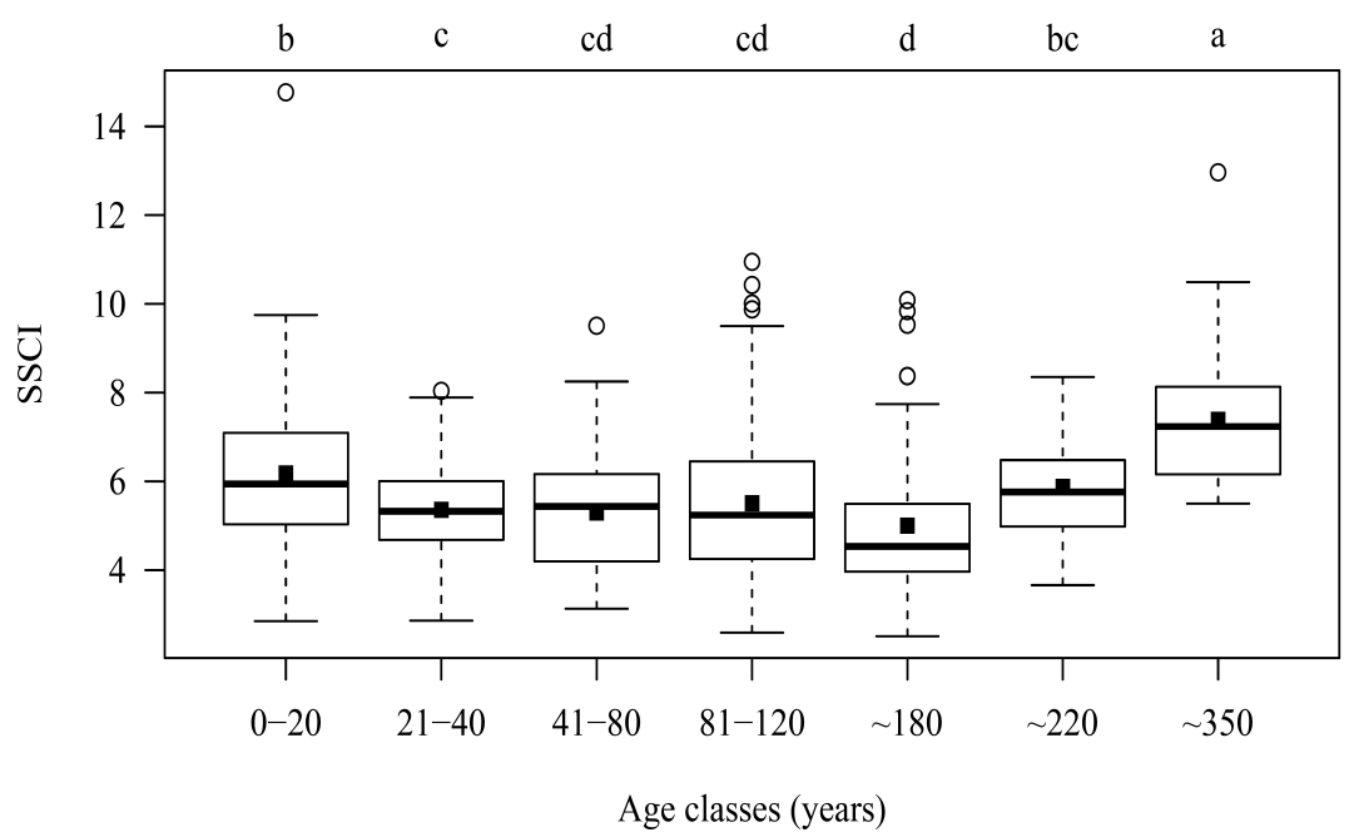

Figure 2.4: Box-Whisker plot of the stand structural complexity index (SSCI) for the different age classes. Black horizontal lines indicate the median, black points mark the mean values. ( $\mathrm{n}=120$ for "0-20","2140 ","41-80","81-120", $\mathrm{n}=60$ for “ $\sim 180 ", \mathrm{n}=30$ for " $220 ",, \sim 350)$. Different lowercase letters indicate significant differences among the age classes at the level of $\mathrm{p}<0.05$.

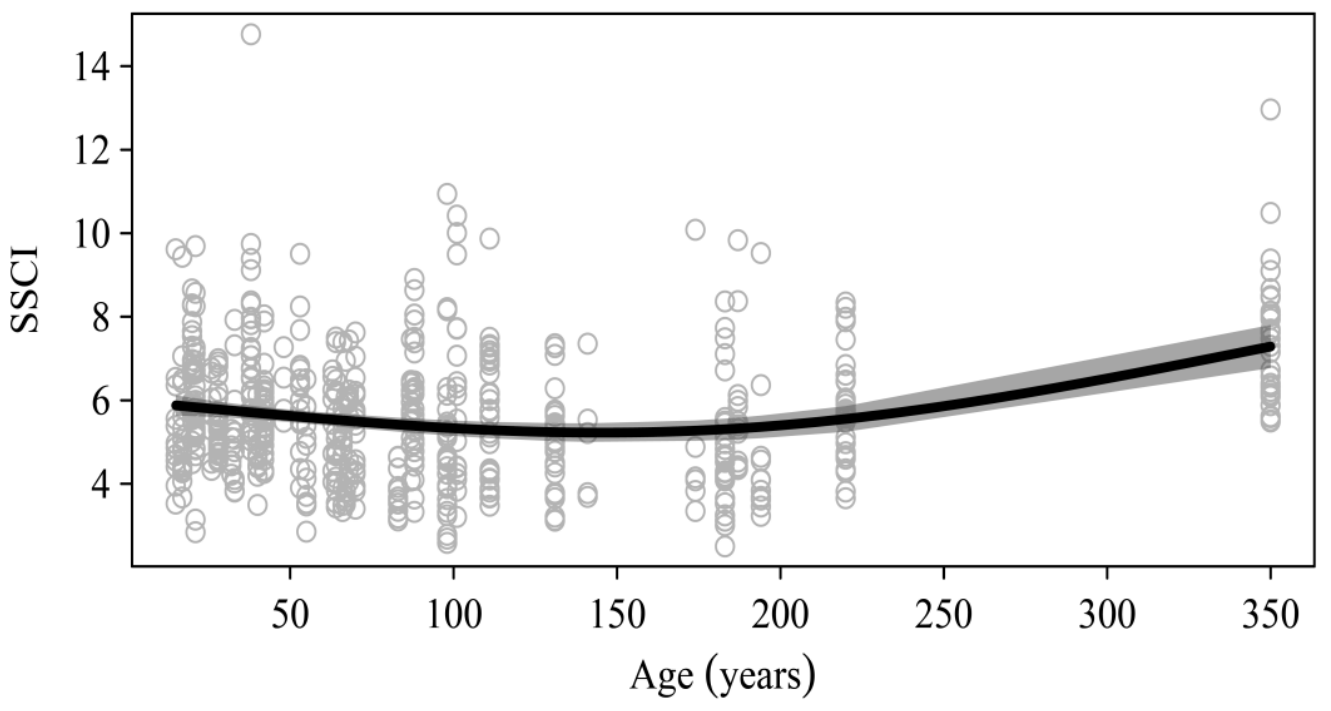

Figure 2.5: Scatterplot of the stand structural complexity index (SSCI) over stand age (majority of trees). The solid black line describes the significantly non-linear trend in the data, derived from the generalized additive models $(\mathrm{p}<0.001, \mathrm{R} \cdot \mathrm{adj}=0.085$ ). The grey area indicates the $95 \%$ confidence interval. 
The SSCI also differed significantly between several of the eight study areas ( $p<0.001)$. It was particularly noticeable that the SSCI differed significantly between the two primary forests $(\mathrm{p}=0.0099)$, with Uholka being larger than Rožok. Actually, the SSCI of Rožok was more similar to the four managed forests. The lowest structural complexity was measured in the Hainich National Park, where the values were significantly lower than in most of the other stands except for the Kellerwald National Park and the managed forest in Ebrach. Considering the coefficient of variation (cv \%), the highest variation in SSCI between the sample points was found in the National Parks, while the variance in managed and primary forests was comparatively low (see Tab. 2.2).

Even though significant differences could be detected between the management types and age classes, the SSCI generally showed a high variability throughout the measurements and in all management types.

Table 2.2: Descriptive statistics of stand structural complexity (SSCI) in the eight different study areas; $\min =$ minimum, $\max =$ maximum, $\mathrm{sd}=$ standard deviation, $\mathrm{cv}=$ coefficient of variance . Different lowercase letters indicate significant differences among the eight study areas at the level of $\mathrm{p}<0.05$.

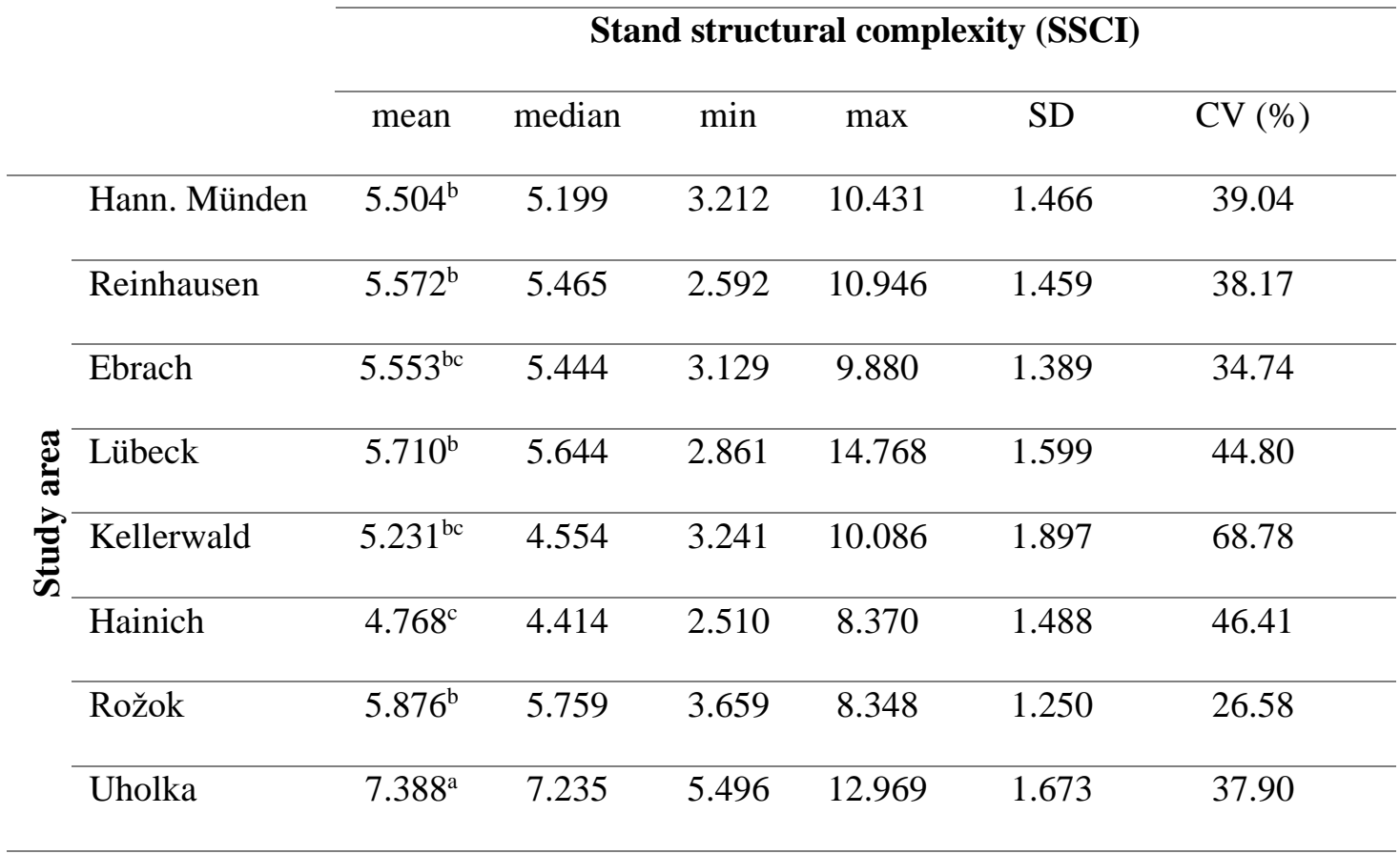




\subsection{Discussion}

\subsubsection{Effects of management type and age on structural complexity of beech forests}

Forest structure is an important feature of forest ecosystems affecting biodiversity, productivity, stability and resilience (Pretzsch 1998, Pommerening 2002, Nagel et al. 2013, Ehbrecht et al. 2016, Feldmann et al. 2018a). However, it is controversially discussed how structural complexity, as high and as close as possible to natural development, can be achieved. It is questionable, whether further management or ceasing management interventions promotes and enriches the stand structural complexity of a forest (Commarmot et al. 2005, Meyer 2005). We initially hypothesized structural complexity would increase with decreasing management intensity (i). In fact, our results indicate that forest management affects stand structural complexity. But the initially hypothesized linear trend was not found in this clarity. The results show no significant differences between the age class 0-20 in managed and 220 years in primary forests (Fig. 2.4). There were also differences between the same forest types, e.g. Uholka and Rožok as primary forests (Tab. 2.2 and Fig. 2.4). Finally, there was a generally large scatter of the SSCI values (Tab. 2.2) and the range of the mean SSCI values was lower than initially expected.

Against this background we can conclude that silvicultural activities do not necessarily decrease the structural complexity of beech dominated forests and presumably also of other forest ecosystems. However, we could not confirm our first hypothesis (i) because we could not detect a general increase from the managed forest over the formerly managed and now unmanaged National Parks to the primary forests. On the contrary, the lower SSCI results found in the two National Parks suggest that setting-aside formerly managed forests in the mature timber stage (around 120-150 years) might prolong the development of structurally rich forests by several decades because no artificial disturbances (tree harvests) and nearly no natural disturbances occur. In both National Parks, a period of up to 30 years without management did not yet initiate stand structural complexity similar to primary forests. However, the designation of National Parks aims at allowing and protecting a management free development and natural processes. Considering stand cycles in primary forests 30 years cover a rather short time span.

Ehbrecht et al. (2017) showed that the SSCI increased with the presence of understory trees below the main canopy. This explains the marked differences between the high SSCI values of the thickets with overstory trees (age class 0-20 years) and comparatively low 
SSCI values of the immature and mature single-layered timber stands (age classes 21-120 years) in this study. Considering the significant non-linear trend within the data (Fig. 2.5) it appears as if the structural complexity continuously decreases from age 20 onwards down to the minimal values around 180 years. However, as shown in Fig. 2.4, there were no significant differences between the stand ages 20 to 120 . This shows that the singlelayered "vault-like" beech forests (German: "Hallenwälder") are structurally least complex due to the absence of more than one pronounced stand layer. This also shows that low structural complexity is age independent, once additional stand layers are dissolved through management. Finally, this is a confirmation for our second hypothesis (ii), stating that there are significant differences among the age classes. These "vault-like" forests are a consequence of the high crown plasticity of European beech, because beech crowns respond quickly to changes in light availability (Feldmann et al. 2018a). Especially, small canopy gaps are quickly closed through horizontal crown expansion of adjacent beech trees (Feldmann et al. 2018a). Hence, the time span for an understory layer to develop in dense beech forests is too small, leading to single-layered and less structured forests (Feldmann et al. 2018a, Pretzsch and Schütze 2005). This is typical for beech stands in the optimum phase and is well documented in the literature (Boncina 2000, Leibundgut 1978, Scherzinger 1996, Meyer 2005). Actually, our study revealed a rather long period of time, including the growth and optimum phase, which is characterized by a low structural complexity in managed forests (see Fig. 2.4, 2.5 and 2.6). However, taking the findings from Rožok into account, our results suggest that also primary forests can be comprised of similar structural configurations in terms of the three-dimensional arrangement of biomass. The higher values in Uholka seemed to be mainly driven by the pronounced natural decay of overstory trees resulting in a well-developed understory. Some plots of the National Parks showed similar signs of decay, but the majority of these forests are still in the long-lasting more or less single-layered optimum phase (Drößler and Meyer 2006). Therefore, if the development towards a higher structural heterogeneity should be accelerated, it may be considered to artificially create larger canopy gaps before ceasing management.

However, it is a question of time until the two National Parks will have developed oldgrowth structures on a larger scale (Meyer 2005, Nagel et al. 2013). We can only speculate how long this will take. Apparently, the state of the forests at the time of being set-aside from management has a rather strong influence (Trotsiuk et al. 2012). An active promotion of old-growth structures through preliminary interventions might shorten this 
time. Next to setting-aside forests, it is therefore important to emulate key attributes of old growth forests in managed stands as well, while also complying with social and economic management goals.

Interestingly, our results showed a significant difference between the stand structural complexities in the two examined primary forests (see Tab. 2.1) of which one (Rožok) was not significantly different from the managed forests. One possible explanation for these differences is the disturbance regime and the development history of the two forests (Leibundgut 1978). Inventory results of Commarmot et al. (2005) in the primary forest Uholka showed a distinct uneven-aged structure with a large range of different diameter classes and tree ages. This was confirmed by the high structural complexity measured in our study. In contrast, Rožok appeared to be largely dominated by single-layered stands and a smaller range of tree ages. Leibundgut (1978) traced this structure back to evenaged regeneration cohorts following large-scale natural disturbances such as storms, which are generally considered to be rather rare in central Europe (Feldmann et al. 2018a, Trotsiuk et al. 2012) but which may play a more important role than previously thought (Nagel et al. 2006, 2014, 2017; Jaloviar et al. 2017). It may therefore be that the lower stand structural complexity in Rožok results from different stand dynamics, which is reflected by less old trees, compared to Uholka. Linking the forest structure to stand age (see Fig. 2.5) reveals an increase in stand structural complexity beginning around an age of 200 years. Thus, the transition from the structurally less complex optimal phase to the more complex decay phase seems to start at about this age in beech-dominated forests. Accordingly, Rožok with an estimated age of around 220 years is in the transition phase, while in Uholka, containing trees 350 years old, the decay phase has already lasted for a longer time period.

In our study, both management type and age varied simultaneously for the stands beyond 120 years of age. Due to the existing management regimes in Central Europe, we were unable to identify primary beech forests younger than 220 years and none of the available managed stands was older than $\sim 120$ years. Investigating forest structure along a gradient of stand ages only, in absence of management effect, was hence impossible for beech-dominated forests. Our comparison of management types indicated that silvicultural intervention does not necessarily lead to a loss in structural complexity.

Previous research on the floristic and faunistic diversity across developmental phases revealed the patterns illustrated in Figure 2.6 (e.g. Boncina 2000, Brunet et al. 2010, 
Scherzinger 1996). Our data shows that these patterns in beech-dominated forests may be the result of a surprisingly similar pattern of structural complexity. Consequently, we speculate that the period of low floristic and faunistic biodiversity (Scherzinger 1996), is driven by low stand structural complexity (see Fig. 2.6). With a promotion of structural complexity, it should thus be possible to increase floristic and faunistic biodiversity as well.

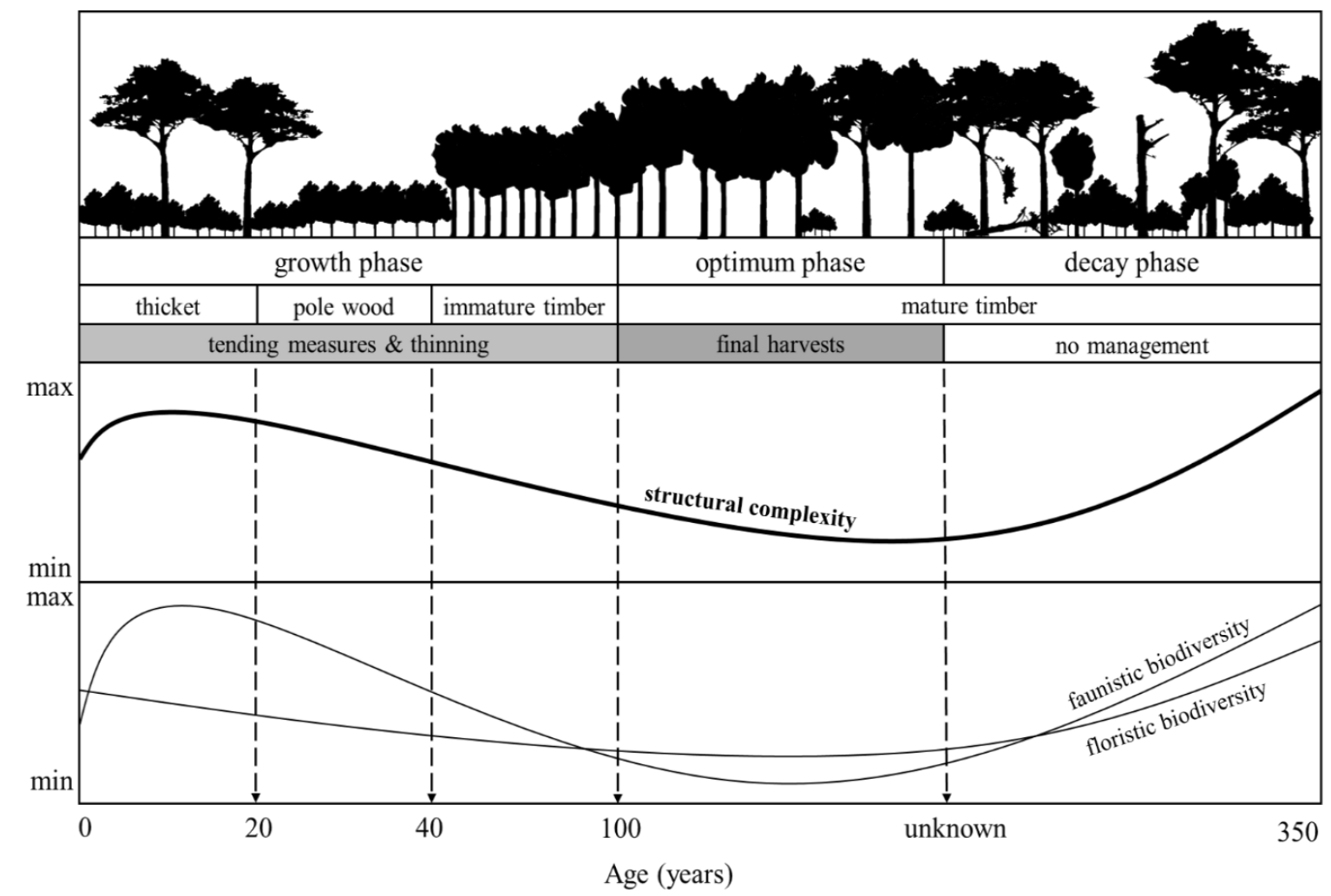

Figure 2.6: Dynamics of faunistic and floristic biodiversity and structural complexity in beech dominated forest Ecosystems in dependence of age and different forest development phases. The hypothetical chronological progression of the stand structural complexity curve was derived from the measurements and Generalized Additive Model analysis presented in Fig. 2.5. Lines for floristic and faunistic biodiversity were created according to Scherzinger (1996).

Our results further indicate that management practices in forests increase the stand structural complexity when they result in stands with more than one layer. It was frequently reported that single-tree- or group-selection best imitate the gap dynamics and natural regeneration processes in primary beech forests (Meyer et al. 2003, Commarmot et al. 2005, Brunet et al. 2010, Nagel et al. 2013). Tree harvests that result in canopy openings large enough to induce natural regeneration but small enough to not strengthen grass species that may prevent or outcompete natural regeneration (Wagner et al. 2011), imitate small-scale patchiness, observed in various primary forests (Korpel' 1995, Nagel 
et al. 2013, Tabaku 1999). Overall a patchwork of forest gaps of varying size (e.g. through group-selection) appears to maintain a multi-layered forest and to avoid vault-like structures.

As the coefficient of variation of the SSCI between the scan positions represents plot-toplot heterogeneity of structural complexity, the interplay between patches of closed and single-layered forest and gradual regeneration in canopy gaps causes large variability in the SSCI. This variability is particularly high in the National Parks, especially in the Kellerwald National Park where both were found, vault-like forest patches and regeneration patches caused by single-tree death (see Tab. 2.2).

In the primary forest Uholka, high SSCI values resulted from young cohorts intermingled with older trees in small-scale patches. Thus, the structural complexity in thickets can be increased by remaining scattered shelterwood trees. In traditional management systems, sheltering trees and seed trees are removed within a time period of up to 30 years. To increase the structural complexity of these final harvest stands it would be beneficial to not remove all overstory trees as suggested by the retention tree approach (Gustafsson et al. 2010, 2012). However, leaving shelter trees comes with the risk of financial wood devaluation with increasing tree age (e.g. "red heart" in beech), which reduces economic benefits and possible uses. Finally, such trees are a considerable threat to forest workers.

\subsubsection{Methodical considerations}

It is worth mentioning that SSCI only quantifies forest structures in terms of the spatial, three-dimensional organization of objects. However, other aspects of structural elements, for example the level of decomposition of coarse woody debris, the number of microhabitats and the presence of habitat trees are not represented by this index. Consequently, we are only able to refer to structural elements that increase the SSCI, if this was the aim for the future forest development.

Covering beech forests from various sites in three European countries, our sites slightly differed with regard to the soil conditions and other environmental characteristics (climatic conditions, herbivore fauna, etc.). Since forests located in valleys are generally more strongly influenced by human activities because of their higher accessibility (Tabaku 1999), there are no primary beech forests on flat terrain left in Europe. While slope effects were inherently considered in the SSCI approach we cannot exclude possible 
effects on the structural complexity of the stands due to differences in soil conditions, herbivory, climate etc.

Overall, the SSCI-values had a high scatter within the observational units and a rather small but partly significant range between them (Fig. 2.3, 2.4 and 2.5). To some degree, this was most likely caused by predefined similarities of the investigated forest types: European beech contributed to the basal area of the stand of at least $66 \%$.

\subsection{Conclusions}

Our results show that a management abandonment during the optimum phase does not increase the structural complexity on short notice. In contrast, the stands continue to grow and do not enter the decay phase for some decades. To counteract this possibly long period of low structural complexity in National Parks, silvicultural management practices, e.g. creating canopy openings similar to what can be found in primary forests, considering spatial and temporal gap dynamics, could be applied before ceasing all management activity, if the aim is to quickly create structurally rich forests.

Overall, our results show the importance of different stand layers for the structural complexity in forests. Overstory trees significantly increase stand structural complexity in thickets compared to single layer stands. Therefore, management practices could promote multiple stand layers and enhance stand structural complexity in beechdominated forests. Our findings may help integrating structural information in decision making (e.g. conservation vs. management) and may facilitate the promotion of structures related to certain forest functions.

\subsection{Acknowledgements}

The Dr. Erich Ritter-Foundation (T0021/29427/2017) is greatly acknowledged for funding this work. The German Research Foundation through grant SE2383/4-1 also funded part of this work. We thank all persons that gave us access to the forest districts they are responsible for: Axel Pampe, Dr. Thomas Schmidt-Langenhorst, Sabine Steinhoff, Knut Sturm, Manfred Großmann, Manfred Bauer, Achim Frede, Bernd Schock, Ulrich Mergner, Martin Schafhirt, Peter Jaloviar, and Vasyl Lavnyy. Permits for accessing the primary forests and fieldwork were issued by the responsible environmental protection office in Presov and administration of "Poloniny National park" for Slovakia and Carpathian Biosphere Reserve for Ukraine. 


\subsection{References}

Bauhus, J., Puettmann, K., Messier, C. (2009): Silviculture for old-growth attributes. Forest Ecology and Management, 258, 525-537.

Boncina, A. (2000): Comparison of structure and biodiversity in the Rajhenav virgin forest remnant and managed forest in the Dinaric region of Slovenia. Global Ecology \& Biogeography, 9, 201-211.

Brang, P. (2005): Virgin forests as a knowledge source for central European silviculture: reality or myth. For. Snow. Landsc. Res. 79, 1/2: 19-32.

Brunet, J., Fritz, Ö., Richnau, G. (2010): Biodiversity in European beech forests - a review with recommendations for sustainable forest management. Ecological Bulletins, 53, 77-94.

Cianelli, L., Chan, K., Bailey, K.M., Stenseth, N.C. (2004): Nonadditive effects of the environment on the survival of a large marine fish population. Ecology, 85, 3418-3427.

Commarmot, B., Bachofen, H., Bundziak, Y., Bürgi, A., Ramp, B., Shparyk, Y., Sukhariuk, D., Viter, R., Zingg, A. (2005): Structures of virgin and managed beech forests in Uholka (Ukraine) and Sihlwald (Switzerland): a comparative study. For. Snow Landsc. Res. 79, $1 / 2,45-56$.

Drößler, L., Meyer, P. (2006): Waldentwicklungsphasen in zwei Buchen-Urwaldreservaten in der Slowakei. Forstarchiv, 77, 155-161.

Ehbrecht, M., Schall, P., Juchheim, J., Ammer, C., Seidel, D. (2016): Effective numbers of layers: A new measure for quantifying three-dimensional stand structure based on sampling with terrestrial LiDAR. Forest Ecology and Management, 380, 212-223.

Ehbrecht, M., Schall, P., Ammer, C., Seidel, D. (2017): Quantifying stand structural complexity and its relationship with forest management, tree species diversity and mircoclimate. Agricultural and Forest Meteorology, 242, 1-9.

Ellenberg, H., Leuschner, C. (2010): Vegetation Mitteleuropas mit den Alpen in ökologischer, dynamischer und historischer Sicht. 6. Auflage 2010, Verlag Eugen Ulmer KG.

EUFORGEN (2009): Distribution map of Beech (Fagus sylvatica), www.euforgen.de.

Feldmann, E., Drößler, L., Hauck, M., Kucbel, S., Pichler, V., Leuschner, C. (2018a): Canopy gap dynamics and tree understory release in a virgin beech forest, Slovakian Carpathians. Forest Ecology and Management, 415-416, 38-46.

Feldmann, E., Glatthorn, J., Hauck, M., Leuschner, C. (2018b): A novel empirical approach for determining the extension of forest development stages in temperate old-growth forests. European Journal of Forest Research, 137 (3), 321-335. 
Gadow, K., Zhang, C.Y., Wehenkel, C., Pommerening, A., Corral-Rivas, J., Korol, M., Myklush,S., Hui, G.Y., Kiviste, A., Zhao, X.H. (2012): Forest structure and diversity. In: Pukkala, T., Gadow, K. (eds): Continuous cover forestry. Managing forest ecosystems, vol. 23. Springer, Dordrecht.

Glatthorn, J., Feldmann, E., Pichler, V., Hauck, M., Leuschner, C. (2017): Biomass Stock, Productivity of Primeval, and Production Beech Forests: Greater Canopy Structural Diversity Promotes Productivity. Ecosystems.

Gustafsson, L., Kouki, J., Sverdrup-Thygeson, A. (2010): Tree retention as a conservation measure in clear-cut forests of northern Europe: A review of ecological consequences. Scand. J. For. Res. 25, 295-308.

Gustafsson, L., Baker, S.C., Bauhus, J., Beese, W.J., Brodie, A., Kouki, J., Lindenmayer, D.B., Löhmus, A., Pastur, G.M., Messier, C., Neyland, M., Palik, B., Sverdrup- Thygeson, A., Volney, Q.J.A., Wayne, A., Franklin, J.F. (2012): Retention forestry to maintain multifunctional forests: a world perspective. BioScience, vol. 62 no. 7, 633-645.

Hastie, T.J., Tibshirani, R.J. (1990): Generalized additive models, 1. ed., 1. CRC reprint. Monographs on statistics and applied probability, vol 43. Chapman \& Hall/CRC, Boca Raton.

Hobi, M. L., Commarmot, B., Bugmann, H., \& Woods, K. (2015). Pattern and process in the largest primeval beech forest of Europe (Ukrainian Carpathians). Journal of Vegetation Science, 26(2), 323-336.

Jaloviar, P., Saniga, M., Kucbel, S., Pittner, J., Vencurik, J., Dovciak, M. (2017): Seven decades of change in a European old-growth forest following a stand-replacing wind disturbance: A long-term case study. Forest Ecology and Management 399 (2017): 197-205.

Juchheim, J., Annighöfer, P., Ammer, C., Calders, K., Raumonen, P., Seidel, D. (2017): How management intensity and neighborhood composition affect the structure of beech trees. Trees, 31 (5), 1723-1735.

Knoke, T., Seifert, T. (2008): Integrating selected ecological effects of mixed European beechNorway spruce stands in bioeconomic modelling. Ecological Modelling 210 (2008): 487498.

Korpel', S. (1995): Die Urwälder der Westkarpaten. Gustav Fischer Verlag.

Kucbel, S., Saniga, M., Jaloviar, P., Vencurik, J. (2012): Stand structure and temporal variability in old-growth beech-dominated forests of the northwestern Carpathians: A 40-years perspective. Forest Ecology and Management 264 (2012): 125-133. 
Leibundgut, H. (1978): Über Zweck und Probleme der Urwaldforschung. Allgemeine Forstzeitschrift AFZ, 33 (1978): 683.

Messier, C., Puettmann, K.J. (2011): Forests as complex adaptive systems: implications for forest management and modelling. Italian Journal of Forest and Mountains Environments 66 (3): 249-258.

Meyer, P., Tabaku, V., v. Lüpke, B. (2003): Die Struktur albanischer Rotbuchen-Urwälder Ableitungen für eine naturnahe Buchenwirtschaft. Forstw. Cbl. 122 (2003): 47-58.

Meyer, P. (2005): Network of strict forest reserves as reference system for close to nature forestry in Lower Saxony, Germany. For. Snow Landsc. Res. 79, 1/2: 33-44 (2005).

Nagel, T.A., Svoboda, M., Diaci, J. (2006): Regeneration patterns after intermediate wind disturbance in an old-growth Fagus-Abies forest in southeastern Slovenia. Forest Ecology and Management, 226 (1-3), 268-278.

Nagel, T.A., Svoboda, M. (2008): Gap disturbance regime in an old-growth Fagus-Abies forest in the Dinaric Mountains, Bosnia-Herzegovina. Canadian Journal of Forest Research, 38 (11), 2728-2737.

Nagel, T.A., Zenner, E., Brang, P. (2013): Research in old-growth forests and forest reserves: implications for integrated forest management. Integrative approaches as an opportunity for the conservation of forest biodiversity. Freiburg: European Forest Institute, 44-50.

Nagel, T.A., Svoboda, M., Kobal, M. (2014): Disturbance, life history traits, and dynamics in an old- growth forest landscape of southeastern Europe. Ecological Applications, 24 (4), 2014, 663- 679 .

Nagel, T.A., Mikac, S., Dolinar, M., Klopcic, M., Keren, S., Svoboda, M., Diaci, J., Boncina, A., Paulic, V. (2017): The natural disturbance regime in forests of the Dinaric Mountains: A synthesis of evidence. Forest Ecology and Management 388 (2017), 29-42.

NLF - Niedersächsische Landesforsten: Entscheidungshilfen zur Behandlung und Entwicklung von Buchenbeständen. Accessible online (last access 26th July 2018): https://www.nwfva.de/fileadmin/user_upload/Verwaltung/Publikationen/Merkblaetter/Bu_Nds_Entsche idungshilfen_zur_Behandlung_und_Entwicklung_von_Buchenbestaenden.pdf.

Otto, S.A., Diekmann, R., Flinkman, J., Kornilovs, G., Möllmann, C. (2014): Habitat heterogeneity determines climate impact on zooplankton community structure and dynamics. PLoS ONE 9:e90875.

Paffetti, D., Travaglini, D., Buonamici, A., Nocentini, S., Vendramin, G.G., Giannini, R., Vettori, C. (2012): The influence of forest management on beech stand structure and genetic diversity. Forest Ecology and Management 284 (2012): 34-44. 
Pommerening, A. (2002): Approaches to quantifying forest structures. Forestry, Vol. 75, No. 3: 305- 324.

Pretzsch, H. (1998): Structural diversity as a result of silvicultural operations. Lesnictvi- forestry, 44, 1998 (10): 429-439.

Pretzsch, H., Schütze, G. (2005): Crown Allometry and Growing Space Efficiency of Norway Spruce and European Beech in pure and mixed stands. Plant Biology 7 (2005): 628-639.

R Core Team (2017): R: A language and environment for statistical computing. R Foundation for Statistical Computing, Vienna, Austria. URL https://www.R-project.org/.

Schall, P., Gossner, M.M., Heinrichs, S., Fischer, M., Boch, S., Prati, D, ... \& Buscot, F. (2018a): The impact of even-aged and uneven-aged forest management on regional biodiversity of multiple taxa in European beech forests. Journal of Applied Ecology 55: 267-278.

Schall, P., Schulze, E.-D., Fischer, M., Ayasse, M., Ammer, C. (2018b): Relations between forest management, stand structure and productivity across different types of Central European forests. Basic and Applied Ecology, 32, 39-52.

Scherzinger, W. (1996): Naturschutz im Wald, Qualitätsziele einer dynamischen Waldentwicklung. Verlag Eugen Ulmer \& Co.

Seidel, D., Ehbrecht, M., Puettmann, K. (2016): Assessing different components of threedimensional forest structure with single-scan terrestrial laser scanning: A case study. Forest Ecology and Management 381 (2016): 196-208.

Tabaku, V. (1999): Struktur von Buchen-Urwäldern in Albanien im Vergleich mit deutschen Buchen- Naturwaldreservaten und -Wirtschaftswäldern. Dissertation. Cuvillier Verlag Göttingen.

Trotsiuk, V., Hobi, M.L., Commarmot, B. (2012): Age structure and disturbance dynamic of the relic virgin beech forest Uholka (Ukrainian Carpathians). Forest Ecology and Management 265 (2012): 181-190.

Wagner, S., Fischer, H., Huth, F. (2011): Canopy effects on vegetation caused by harvesting and regeneration treatments. Eur. J. For. Res. 130:17-40.

Winter, S., Brambach, F. (2011): Determination of a common forest life cycle assessment method for biodiversity evaluation. Forest Ecology and Management 262 (2011): 2120-2132.

Wood, S.N. (2006): Generalized additive models: An introduction with R. Texts in statistical science. Chapman \& Hall/CRC, Boca Raton. 
Wood, S.N. (2011): Fast stable restricted maximum likelihood and marginal likelihood estimation of semiparametric generalized linear models. Journal of the Royal Statistical Society (B) $73: 3-36$.

Zenner, E.K., Peck, J.E., Hobi, M.L., Commarmot, B. (2016): Validation of a classification protocol: meeting the prospect requirement and ensuring distinctiveness when assessing forest development phases. Applied Vegetation Science 19 (2016): 541-552. 
Chapter 3

\section{Analyzing Spatial Distribution Patterns of European Beech (Fagus sylvatica L.) Regeneration in Dependence of Canopy Openings}

This chapter is published as research article in Forests, 10, 637, 28. July 2019, MPDI. 


\title{
Analyzing Spatial Distribution Patterns of European Beech (Fagus sylvatica L.) Regeneration in Dependence of Canopy Openings
}

\author{
Melissa Stiers $^{1 *}$, Katharina Willim ${ }^{1}$, Dominik Seidel ${ }^{1}$, Christian Ammer $^{1}$, Myroslav \\ $\mathrm{Kabal}^{2}$, Jonas Stillhard ${ }^{3}$ and Peter Annighöfer ${ }^{1}$
}

${ }^{1}$ Silviculture and Forest Ecology of the Temperate Zones, Faculty of Forest Sciences, University of Göttingen, Büsgenweg 1, 37077 Göttingen, Germany

${ }^{2}$ Laboratory of Forest Sciences, Carpathian Biosphere Reserve, Vulytsya Krasne Pleso, 77, 90600 Rakhiv, Ukraine

${ }^{3}$ Forest Resources and Management, Swiss Federal Institute for Forest, Snow and Landscape Research WSL, Zürcherstraße 111, 8903 Birmensdorf, Switzerland

*Correspondence: melissa.stiers@ forst.uni-goettingen.de

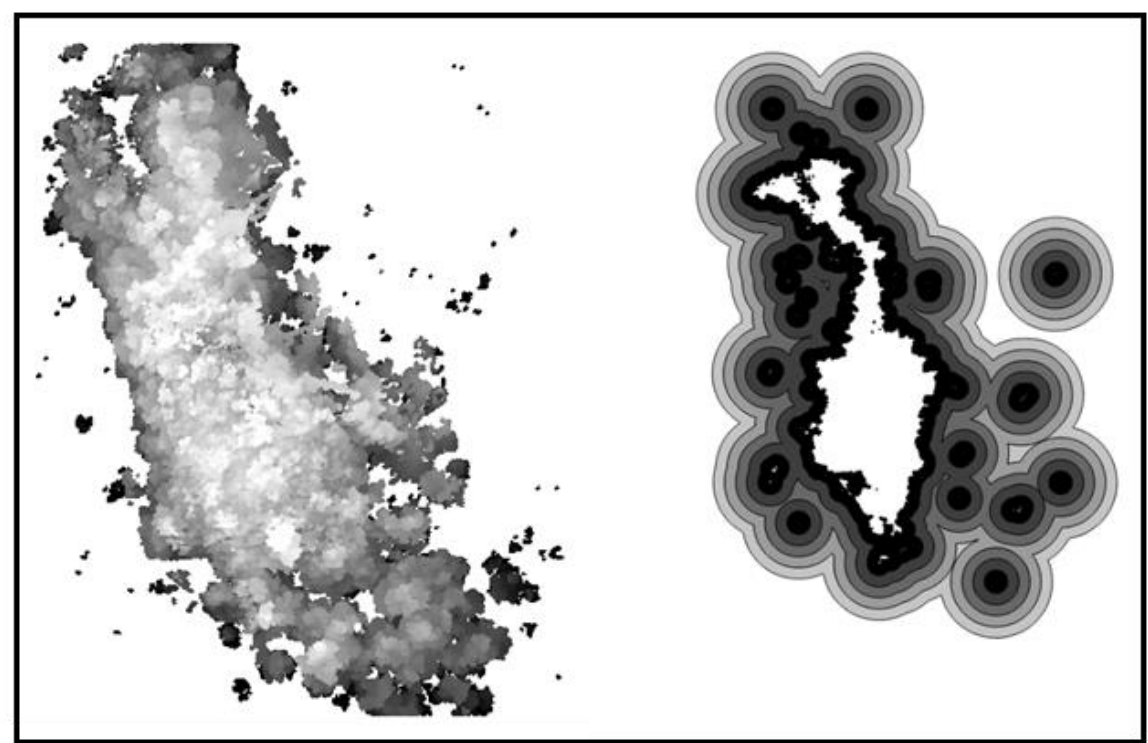

Katharina Willim and Melissa Stiers have contributed significantly to the study concept and design, and planned data acquisition, collected, and evaluated the data. Melissa Stiers was responsible for literature research, statistical data analysis, results and writing the manuscript. Peter Annighöfer and Dominik Seidel supervised the data analyses and together with Christian Ammer, Jonas Stillhard, Katharina Willim and Myroslav Kabal they assisted, reviewed and edited the article draft. 


\begin{abstract}
The use of natural regeneration techniques is one of the key elements of modern (closeto-nature) forestry. In natural forests, changes in canopy cover, such as the emergence and successive re-closure of canopy gaps are particularly important, as they influence the light availability on the forest floor. Creating canopy gaps of different size is a promising silvicultural tool allowing the regulation of the light availability in managed forests in order to control regeneration composition and development. In this study, we used terrestrial laser scanning data to investigate the relationship between canopy-gap dimensions and emerging natural regeneration along a gradient of management in forests dominated by European beech (Fagus sylvatica L.). We analyzed the spatial distribution and height of regeneration patches in dependence of gap characteristics. Mean regeneration height decreases progressively from the gap polygon over a transition zone towards the area under the canopy, while the tallest regeneration plants were placed in positions midway between center and gap edge, and not directly in the gap center as we initially assumed. The centers of regeneration patches were not displaced when compared to the associated canopy gap centers, as has been reported in other studies conducted on the northern hemisphere for various tree species. The observed patterns did not depend on management strategies, indicating that regeneration responded equally to naturally created gaps and gaps that were caused by logging. We conclude that establishment and development of shade-tolerant European beech regeneration in forest stands is driven by gap openings, but not necessarily direct radiation. If at all, pronounced direct radiation mainly occurs at the northern edge of large gaps. Neither regeneration patch center, nor regeneration tree height pointed in that direction. Our study suggests that in the investigated beech-dominated forests the effect of increased light availability at the northern edge of a gap is overruled by other factors increasing towards the gap edge, such as increased belowground competition of the overstory trees.
\end{abstract}

Keywords: natural regeneration, light availability, top-down dependency, shadetolerance, spatial analysis, Carpathian Biosphere Reserve, primary forest 


\subsection{Introduction}

An essential part of modern, close-to-nature silviculture is imitating natural forest dynamics and integrating natural processes, such as natural regeneration (Gustafsson et al. 2012, Nagel et al. 2013). When considering natural forest development, the dynamics of canopy gaps play a major role, as they determine the light availability on the forest floor (Coates 2002, Feldmann et al. 2018). The distribution of light is one of the most crucial abiotic factors, as it does not only affect regeneration dynamics, but it also allows foresters to direct forest development through light-regulating interventions (Muscolo et al. 2014, Meyer and Ammer 2019).

Canopy gaps are not static, but change their size and shape over time as they progressively close through horizontal ingrowth of gap-neighboring trees or vertical ingrowth of understory juvenile trees emerging in the gap (Feldmann et al. 2018, Muscolo et al. 2014, Diaci et al. 2012, Meyer et al. 2003). Especially small gaps are closed within a few years, while larger gaps often expand subsequently due to the death of neighboring trees (Feldmann et al. 2018, Drößler and von Lüpke 2005). This leads to a constant change in light availability for lower canopy layers and regeneration.

Nevertheless, size is an important characteristic of canopy gaps (Muscolo et al. 2014, Canham et al. 1990, Schliemann and Bockheim 2011, Yamamoto 1992, 2000), whereas different gap definitions exist. Runkle (1982) defined a gap as the polygon area directly under a canopy opening without an indication of vertical extension whilst Brokaw (1982) defined a gap more precisely as an opening in the canopy of a forest down through all crown layers to at least $2 \mathrm{~m}$ above ground or below. The latter definition has been used in most studies on canopy gaps (Schliemann and Bockheim 2011). According to Runkle (1992) the most difficult and arbitrary part in gap definition is, when it is merging with the lower stand layers through vertical ingrowth. Thus, it is common to refer to gaps as filled or re-closed, when the next sub-dominant canopy layer has reached $2 / 3$ of the dominant tree height (Feldmann et al. 2018, Drößler and von Lüpke 2005, Runkle 1982, 1992).

Several studies found altered light availability through gaps not only to affect dynamics within but also beyond the canopy gap in the adjacent forest (Canham et al. 1990, Runkle 1982, Canham 1988, 1989, Brown 1996). This led to the definition of the "expanded gap", which not only involves the actual gap, but the polygon created by connecting the trunks of trees bordering the gap (Runkle 1982, 1992). This concept proved particularly useful 
as it includes areas of the forest that are still affected by the gap opening, for example through an increase in light availability, which is not accounted for if only the polygon of the canopy opening is considered.

The understory light regime below the gap and in nearby areas is not only influenced by the gap's size and shape, but also by the crown architecture of bordering trees (Schliemann and Bockheim 2011, Kneeshaw and Bergeron 1998), their position on the gap's edge with respect to compass directions (Coates 2000, 2002, Malcolm et al. 2001) and the geographical location of the gap, e.g., the latitude of the forest stand (Canham et al. 1990). In forests in higher northern latitudes, regeneration at the northern edge of the gap was found to be promoted by a higher sum of light availability over the course of the day. Therefore, it is assumed that there is an offset between the gap center and the regeneration patch center, which means more of the plants regenerating are found to the north compared to the center of the canopy gap (Canham et al. 1990).

There are considerable differences in the responses of native tree species in deciduous forests to changes in the light regime because of canopy gaps (Canham 1988, 1989). While regeneration of shade-tolerant tree species is able to persist under lower light availabilities for long periods of time (Collet et al. 2002, Mitamura et al. 2008), lightdemanding tree species require less time to adapt to changes in light availability due to canopy opening rather than shade-tolerant species (Wagner et al. 2011). However, European beech (Fagus sylvatica L.) is especially known for its high shade-tolerance (Emborg 1998, Petriţan et al. 2007, 2009), which enables regeneration of beech to establish even under low light intensities, for example in small gaps or even under closed canopy (Emborg 1998).

To accurately describe the processes within both the canopy and understory layer, appropriate methods allowing for an accurate measurement of the gaps and the corresponding distribution of tree regeneration are needed. Initially, the complex shapes of gaps and their sizes were approximated using simple geometric models (circles, triangles, ellipses; see for example de Lima (2005)) or they were estimated by conducting varying numbers of measurements from a central position to the gap edge (Green 1996). Such approaches are rather imprecise approximations and can result in considerable error e.g., when deriving the gap area (Seidel et al. 2015). At present, aerial approaches for spectral gap detection (Hobi et al. 2015a), especially airborne LiDAR (light detection and 
ranging) (Koukoulas and Blackburn 2004), are often used to determine the extent of gaps in larger forest areas.

In this study, we used terrestrial laser scanning to create objectively measured threedimensional point clouds reproducing the canopy openings and the spatial arrangement of regeneration in detail. Such point clouds allow analyzing the spatial link between the canopy and the understory to gain a better understanding of the role light availability plays in regeneration ecology within forests. In the following, this relationship between canopy and understory layer is referred to as a top-down relationship. In this study, such data was used to analyze the relationship between canopy gaps including adjacent forest, and the spatial arrangement and height distribution pattern of associated regeneration patches. Data was collected and analyzed along a forest management gradient, from traditionally and alternatively managed stands over lately unmanaged National Parks in Germany to completely unmanaged primary forests in Slovakia and the Ukraine.

The purpose of this study was to investigate relationships between the size and shape of canopy gaps with the size and spatial extent of the regeneration patch underneath. We hypothesized that (a) the regeneration patch size increases with increasing gap size, (b) the regeneration trees growing under the gap polygon are taller than those growing under the closed canopy, while mean regeneration height continuously decreases with increasing distance from the regeneration patch center, (c) the horizontal offset, which means the mismatch of the centers, between a canopy gap and associated regeneration patch is directed towards north, and (d) the tallest trees within the regeneration layer are located in the center of the gap. 


\subsection{Materials and Methods}

\subsubsection{Study Sites}

Eight different study sites (Figure 3.1 and Table 3.1) with two study plots each, resulting in a total of 16 beech-dominated forest plots were selected at latitudes between $48^{\circ} \mathrm{N}$ (Slovakia and Ukraine) and 53 ${ }^{\circ} \mathrm{N}$ (Lübeck, Germany; Figure 3.1 and Table 3.2). Site selection aimed at similar site conditions and age structure throughout all sites. All plots were located in pure stands of European beech or in beech-dominated stands (at least 66 $\%$ basal area represented by beech); in managed forests, most recent interventions dated back at least two years; forest stands were at least in the developmental stage of "mature timber" ( $>80$ years).

The site selection followed a management-intensity gradient from traditionally managed stands, over alternatively managed, lately unmanaged (National Parks) to unmanaged (primary) forests (Figure 3.1 and Table 3.1). Stands within the "traditionally managed" group were managed following the "Guidelines of beech forest management in Lower Saxony" (NLF), which are mainly based on regular thinning cycles of five to ten years and a target diameter harvest around age 120 to 140 years. Stands were chosen in the districts of Hannoversch Münden and Reinhausen (Lower Saxony, Germany).

The "alternative" management group comprised stands with a reduced thinning frequency and intensity. Stands were chosen in the forest districts of Lübeck (Schleswig-Holstein) and Ebrach (Bavaria), both Germany. The management within this group either aimed at higher growing stocks (Lübeck) or a high amount of dead-wood (Ebrach).

Data for lately unmanaged stands was collected in the German National Parks "Hainich" (Thuringia) and "Kellerwald-Edersee" (Hesse). Management has been ceased in both areas for two to three decades.

Two sites in the primary beech forests of the Carpathian Mountains were chosen as unmanaged forests. One was located in Rožok, Slovakia, a highly protected reserve near the Ukrainian border. The other was in Uholka in the Ukrainian UholkaShyrokoluzhansky area, belonging to the Carpathian Biosphere Reserve. More information on the sites can be found in Stiers et al. (2018) and Willim et al. (2019). 


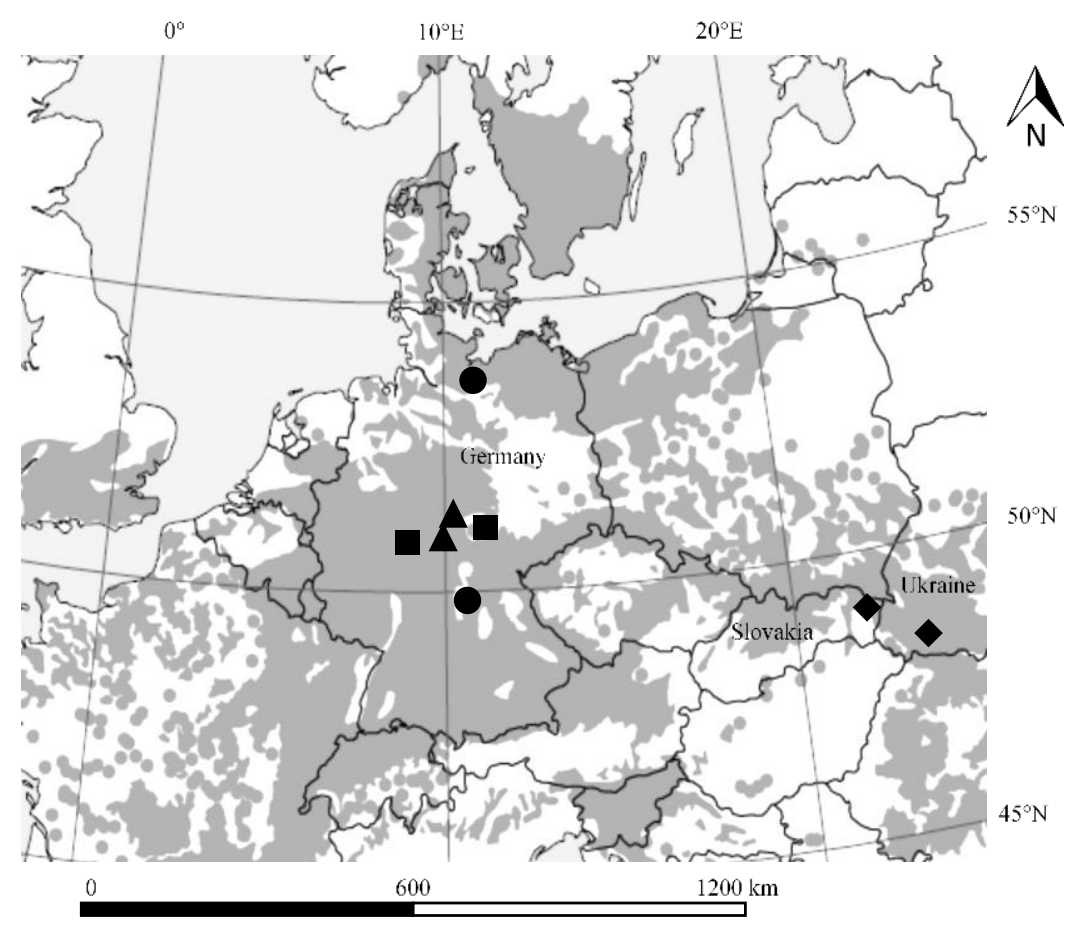

Figure 3.1: Geographic locations of the eight study sites with their management regimes $(\boldsymbol{\Delta}=$ traditionally managed, $\bullet=$ alternatively managed, $\mathbf{\square}=$ National Parks, $\bullet=$ primary forests; modified after Stiers et al. 2018 ) in relation to the potential natural vegetation (grey) of European beech without human influence according to the European Forest Genetic Resources Programme (EUFORGEN; 2009).

Table 3.1: Detailed information about the climatic and geographic conditions of the study areas and the average age of the studied stands. MAT = mean annual temperature; MAP = mean annual precipitation.

\begin{tabular}{ccccccc}
\hline Country & Management Type & Study Sites & $\begin{array}{c}\text { MAT } \\
\left({ }^{\circ} \mathbf{C}\right)\end{array}$ & $\begin{array}{c}\text { MAP } \\
(\mathbf{m m})\end{array}$ & $\begin{array}{c}\text { Elevation } \\
(\mathbf{m} \text { a.s.l.) }\end{array}$ & $\begin{array}{c}\text { Stand Age } \\
(\text { years })\end{array}$ \\
\cline { 2 - 7 } & $\begin{array}{c}\text { Traditionally } \\
\text { managed }\end{array}$ & Hann. Münden & $\begin{array}{c}6.5- \\
7.5\end{array}$ & $\begin{array}{c}750- \\
1050\end{array}$ & $270-410$ & 81 \\
Germany & $\begin{array}{c}\text { Alternatively } \\
\text { managed }\end{array}$ & Ebrach & $7-8$ & 850 & $320-480$ & 111 \\
\cline { 2 - 7 } & $\begin{array}{c}\text { National Park } \\
\text { (lately unmanaged) }\end{array}$ & Lübeck & $8-8.5$ & $625-725$ & $40-90$ & 131 \\
\hline Slovakia & Hainich & $7-8$ & $600-800$ & $330-380$ & 183 \\
\hline Ukraine & $\begin{array}{c}\text { Primary forest } \\
\text { (unmanaged) }\end{array}$ & Rožok & $6-7$ & 780 & $580-745$ & Uneven-aged \\
\cline { 3 - 7 } & & Uholka & 7 & 1407 & $700-840$ & Uneven-aged \\
\hline
\end{tabular}




\subsubsection{Sampling Design and Data Collection (Terrestrial Laser Scanning)}

Within the selected stands, canopy gaps and associated regeneration patches were detected and recorded following pre-defined transect lines (Stiers et al. 2018. Willim et al. 2019). To ensure comparability between different regeneration patches, the age of the regeneration was estimated by counting internodes and was not to exceed 10-15 years. Additionally, the regeneration area was not to be larger than $50 \mathrm{~m} \times 50 \mathrm{~m}\left(2500 \mathrm{~m}^{2}\right)$ to ensure that a complete capture with terrestrial laser scans was possible.

In each forest a plot with an area of $50 \mathrm{~m} \times 50 \mathrm{~m}$ was scanned with a Faro Focus 3D 120 or a Faro Focus M70 (both Faro Technologies Inc., Lake Mary, FL, USA) terrestrial laser scanner, depending on instrument availability. For both instruments, scan settings were set to cover a field of view of $360^{\circ}$ in horizontal and $300^{\circ}$ in vertical direction with an angular resolution of 10.240 points per $360^{\circ}$ with the scanner mounted on a tripod at breast height $(1.30 \mathrm{~m})$. Using phase-difference technology the scanners measured the distance to surrounding trees or other vegetation elements with a maximum distance of 70 (M70) to $120 \mathrm{~m}$ (Focus 120). All scans were conducted in the vegetation periods 2017 and 2018, with all species being densely foliated. In total, 30-80 scans were performed in each plot, depending on the density of the understory vegetation, to ensure capture of every object in the plot with greatest possible detail from several directions and with minimized shadowing (Ehbrecht et al. 2016). For spatial co-registration of the scans with Faro-Software Faro Scene, we evenly distributed 70-90 artificial checkerboard targets throughout the plot. In cases of high regeneration density, it cannot be excluded that there was a shadowing effect in the data (despite very large numbers of scan positions). This could possibly have led to an underestimation of plants in the gap centers or other densely covered areas. To filter for erroneous points according to the standard settings and for the registration we used Faro Scene Software (Faro Technologies Inc., Lake Mary, FL, USA, Version 7.1.1.81).

\subsubsection{Data Analysis of Gap and Understory Characteristics-Size, Shape and Center}

Considering the large number of slightly different gap definitions, we decided to define a canopy opening as canopy gap, when its vertical extension reaches down through all crown layers to a height above ground of at least one third of dominant tree height or below. To sufficiently describe gaps, size, shape and age are important parameters affecting the ecological impact of the respective gap (Schliemann and Bockheim 2011). The data was analyzed following three different approaches (Figure 3.2). To calculate 
and identify shape and size characteristics of the gaps and regeneration patches, as well as availability of direct radiation in canopy gaps, we used delineated polygons of gap and regeneration patch area (Figure 3.2a). To identify the maximum regeneration height within the regeneration patches, we computed a point cloud grid (Seidel et al. 2011) with a resolution of $10 \mathrm{~cm}$ for each regeneration patch and analyzed the offsets between projected gap center and maximum height of the regeneration, and between regeneration patch center and maximum height of the regeneration (Figure 3.2b). Raster data that referred to subsamples of every $50 \mathrm{~m} \times 50 \mathrm{~m}$ plot was used for a top-down analysis of overstory and regeneration dependency. This was conducted to figure out whether the regeneration height differed between the locations directly within the gap polygon or under the canopy (Figure 3.2c).

After combining the single scans into the final multi-scan point cloud, the point cloud was separated into a regeneration layer and a canopy layer (Figure 3.2a) using one third of the dominant tree height as height threshold consistent with our gap definition. For both "layers" we created a separate xyz-file for further processing. In order to identify the canopy gaps in the point clouds we assigned two different colors to regeneration and overstory using the two separate files. After coloring the point clouds both files were looked at from bird's eye perspective and the outline of the gap was manually delineated. Then, the area $\left(\mathrm{m}^{2}\right)$ of the canopy gaps was computed using Delaunay-Triangulation (maximal triangle side length: $0.25 \mathrm{~m}$ ) in Cloud Compare (Version 2.8.1, cloudcompare.org, EDF R\&D, Paris, France). The regeneration patch area was also manually delineated by visual assessment.

Since the gap and regeneration polygons had an irregular shape, we compared two methods to determine the center of the gap and regeneration polygons. Firstly, centers were calculated as intersection point of the two lines bisecting the smallest rectangle that encloses the polygon. Secondly, we defined the center of the polygons as the median of the $\mathrm{X}$ - and $\mathrm{Y}$ - coordinates of the points created during the delineation of the polygons. Because no deviations were found between these variants, only the results of the first method were used afterwards.

While analyzing the associated layers of canopy gaps and regeneration patches it was not always possible to identify a single gap, which solely can be considered responsible for the development of the regeneration patch. In such cases, the areas of all gaps identified 
in the vicinity of the regeneration were summed up and treated as a single gap during analysis.

The horizontal shift between the projected center of the canopy gap and the regeneration center was calculated by subtracting the respective $\mathrm{X}$ - and $\mathrm{Y}$-coordinates (regeneration center - gap center; Figure 3.2a). By calculating the angle $(\cos (\alpha))$ between the twodimensional shift-vector and a north-vector as reference, the offset towards North could be analyzed.



Figure 3.2: Illustration of the three different approaches used in this study. (a) Data analysis to calculate polygon sizes, maximum extents and center positions based on manually delineated polygons. (b) Computing $10 \mathrm{~cm}$ point cloud grids to identify the maximum height within the regeneration patches. (c) Top-down analysis based on raster data of $10 \mathrm{~cm}^{2}$ resolution to analyze the top-down dependency.

To approximate the shape of the canopy gaps, the maximum spatial extent in north-south and west-east directions was calculated (Figure 3.2a). In order to allow conclusions about the shape, a ratio of the extent in both directions was calculated, comparing the real gap shape to a circular gap. For a regular, circular gap, this ratio was 1. For an irregularly shaped gap, elongated along the north-south axis the ratio took values $>1$ and along the west-east axis $<1$. We also calculated the diameter-to-height $(\mathrm{d} / \mathrm{h})$ gap-ratio of each gap as a measure to specify the theoretical availability of direct light in the gap. For the calculation of these gap-ratios, we used the spatial extent of each gap in the north-south direction as an indication for the gap diameter as low solar angles and the course of the 
sun resulted in a higher probability of direct light along the north-south gradient, while height was defined as maximum stand height on plot level. The probability of the incidence of direct light decreased with decreasing gap-ratio.

To analyze the spatial arrangement of plants in relation to the gap or regeneration patch center and to identify the maximum heights within the regeneration patches we computed digital terrain models (DTM) through triangulation of the lowest $\mathrm{z}$-values per $10 \mathrm{~cm}^{2}$ horizontal cell (xy-cell; Figure 3.2b). We then normalized the point cloud of the regeneration patches by correcting each point in the point cloud with the underlying terrain height obtained from the DTM. After normalizing the point cloud, digital surface models (DSM; top of regeneration) were calculated for the 3D point clouds of the delineated regeneration patches. These DSMs were considered to represent the actual heights of the regeneration patches per xy-cell. To calculate the position of the maximum height within the regeneration patch, the maximum height was determined for each xycell of the point cloud grid (Figure 3.2b). Thus, the cell with the greatest height was identified and its xy-coordinates captured to calculate the distances to the center of the regeneration patch and the projected gap center as well as the horizontal shifts between these centers and the largest height. This was done as described above for the shift between gap and regeneration center.

\subsubsection{Direct Radiation on the Forest Floor}

In addition to the gap's shapes and sizes, there are other important factors that influence the availability of light on the forest floor (Muscolo et al. 2014, Schliemann and Bockheim 2011, Messier 1996). One of these factors is the maximum height of the surrounding forest stand (Figure 3.3). In order to determine whether direct light could theoretically reach the forest floor under the gap we further approximated the maximum solar angle at each gap using the formula:

(1) Maximum solar angle $=90^{\circ}$-latitude $+23.43^{\circ}$

with $90^{\circ}$-latitude describing the angle between pole and zenith of the site plus obliquity of the ecliptic of the earth. Based on the data of stand height and maximum solar angle it is possible to calculate a minimum diameter which a circular gap must provide to allow direct sunlight to reach the forest floor in the gap. This minimum diameter was calculated using the Theorem of Pythagoras. To estimate whether direct radiation could potentially 
reach the forest floor we used the maximum extent of the gap (maximum length of a traverse).

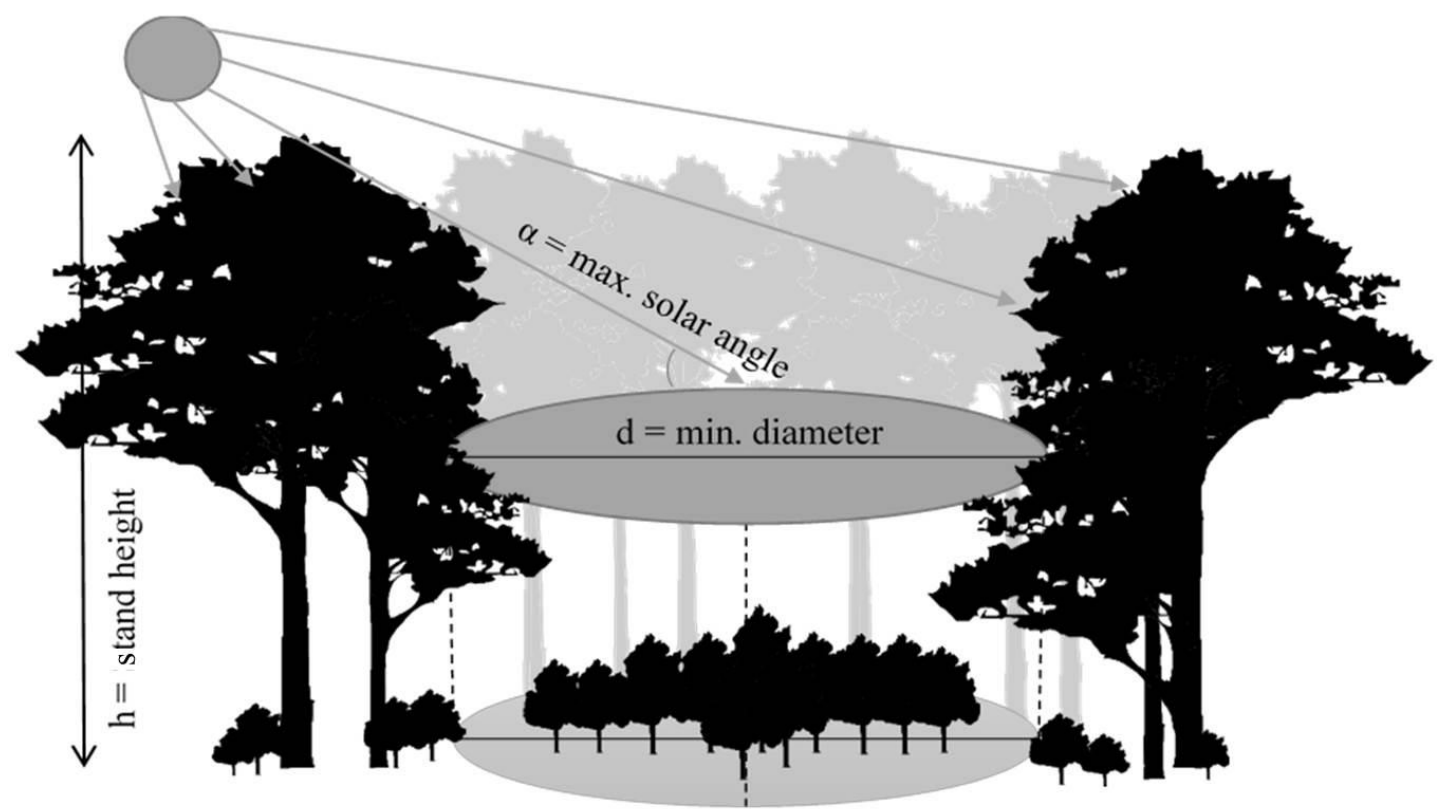

Figure 3.3: Schematic representation of the relationship between stand height (h) and maximum solar angle $(\alpha)$ and the resulting minimum diameter (d) of the canopy gap to allow incidence of direct sunlight.

\subsubsection{Top-Down Analysis}

The term top-down relationship is defined as the dependency of the understory layers on the canopy within a forest (compare above). Here, we especially focus on the spatial link between these layers. We used a top-down dependency analysis to address hypothesis (b), namely whether the height values of the regeneration patches are influenced by a position in the gap polygon or under the canopy (Figure 3.2c). In the first step, the whole multiscan point clouds were transformed into a point cloud grid of $10 \mathrm{~cm}$ resolution. The further analysis refers to subsamples of every transformed multi-scan point cloud by virtually cutting out one rectangular subarea per plot that contains the understory and as many canopy openings as possible. These rectangular subunits of the plots were further subdivided into two layers. The height of each layer was determined by the total stand height in the respective forest scene (Table 3.2). The bottom layer, referred to as "regeneration layer" reached from $0 \mathrm{~m}$ (normalized forest ground) to one third of stand height. The upper layer, referred to as "canopy layer" consisted of all remaining points.

The regeneration layers were further processed to determine understory heights. To do so, first we excluded all xy-cells of the point cloud grid with heights (z-values) lower than $0.5 \mathrm{~m}$ to avoid misinterpretations of dead wood, herbs, shrubs, ferns and grasses. 
Furthermore, stems and low-hanging branches of upper layers were also removed from the point cloud grid (manually) to avoid effects of overstory tree elements before deriving heights (maximum z-value) for each xy-cell in the understory layer.

In the next step, digital surface models (DSM) of both layers were computed (Figure $3.4 \mathrm{a}, \mathrm{c})$ as well as a standardized 1/0-grid for each canopy layer, which was "1" when a canopy element was above the observed xy-cell and " 0 " when there was none (Figure $3.4 \mathrm{~b})$.

In the final steps, the canopy and regeneration raster layers were merged respectively for each plot, and the regeneration was separated into saplings located in the gap (Figure 3.4d) and saplings beneath closed canopy (Figure 3.4f).

To also consider a penumbral zone, which is the adjacent area around a canopy gap that is still affected by canopy opening due to an increase in light levels (Kolari et al. 2006), we defined five buffer zones around the actual gap projection area with a width of $1 \mathrm{~m}$ each (0-1 m; 1-2 m; 2-3 m; 3-4 m; 4-5 m) (e.g., buffer zone 1 (0-1 m); Figure 3.4e). The term "under closed canopy" may be misleading as the regeneration in the buffer zones was already beneath closed canopy as well. Here, "under closed canopy" stands for regeneration heights that were neither part of the gap nor the defined buffer zones. This was done to specifically compare regeneration areas in the zone of transition between the gap and the closed stand surrounding it. 

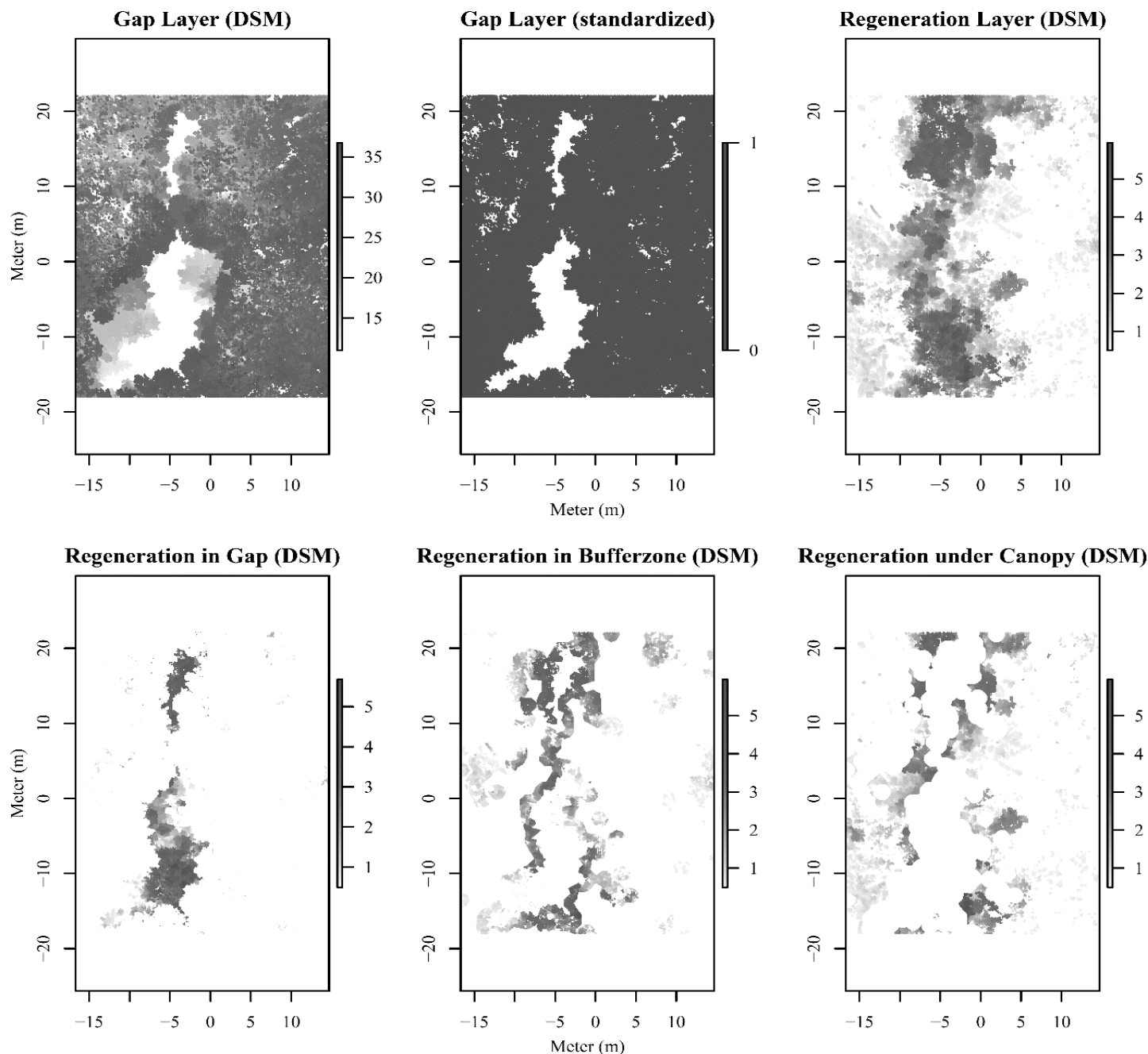

Figure 3.4: Exemplary maps of horizontal (xy)-cells based on the point cloud grid of a plot, here from one of the Hainich sites. Digital surface models of gap layer (a) and regeneration layer (c), standardized 0/1 canopy layer showing the gap $(\mathbf{b})$. $(\mathbf{d}-\mathbf{f})$ : Elements of the regeneration layer located in the gap (d), in a buffer zone of $1 \mathrm{~m}$ around regeneration in gap (e) (here exemplary buffer zone 0-1 $\mathrm{m}$ ), and (f) remaining regeneration under densely closed canopy. DSM = digital surface model.

\subsubsection{Statistical Analysis}

We used parametric or non-parametric tests to analyze the data, depending on whether parametric assumptions (normal distribution and homogeneity of variance) were fulfilled (Shapiro-Wilk test for normality and Levene test for homogeneity of variance). If all parametric assumptions were met, we used one-way ANOVA, whenever these could not be confirmed the Kruskal-Wallis ANOVA was applied as a non-parametric test. For posthoc comparisons between the different variables we used parametric TukeyHSD test or nonparametric Mann-Whitney-U test. This way, we tested for significant differences between gap sizes among the types of management. Concerning regeneration heights, we tested for significant differences depending on the position of the regeneration area. The 
latter was tested for each plot, each type of management, and the full dataset. Furthermore, we tested for significant differences in height decline from within-gap positions over transition zone to positions under canopy on plot level. To analyze the relationship between gap size and regeneration patch area we used a linear regression model. The raster data was created with the R package "lidR" (Roussel and Auty 2019) and analyzed with the R package "raster" (Hijmans 2017). For all statistical tests, we used a significance level of $\mathrm{p}<0.05$. The statistical analyses were conducted with $\mathrm{R}$ (R Core Team 2017).

\subsection{Results}

\subsubsection{Gap, Understory and Light Regulating Characteristics}

In total, we measured extents and gap characteristics of 36 canopy gaps (Table 3.2). Gap size varied between $85.76 \mathrm{~m}^{2}$ in Hainich National Park and $439.98 \mathrm{~m}^{2}$ in the Rožok primary forest. We found no significant differences in mean gap size between the types of management $(\mathrm{F}=1.846, \mathrm{df}=3)$. Mean size of all investigated gaps was $234.31 \mathrm{~m}^{2}$, with only four gaps larger than $400 \mathrm{~m}^{2}$ whilst the mean area under regeneration was $604.40 \mathrm{~m}^{2}$, with the biggest values in primary forests (mean $=910.02 \mathrm{~m}^{2}$ ), and the lowest area in one of the sites of alternative management $\left(\right.$ mean $\left.=205.18 \mathrm{~m}^{2}\right)$.

Gap characteristics such as size and maximum extent of the canopy gaps differed considerably between the different forest plots (Table 3.2). When we tested the relationship between gap size and resulting regeneration area, we found no significant relationship between gap size and the size of the resulting regeneration area based on the delineated gap and regeneration patch polygons (Figure 3.5a; $\mathrm{p}=0.095, \mathrm{~F}=3.19$,

$\mathrm{df}=15$ ). However, the relationship between the sizes of gap and regeneration area became significant concerning the raster data in the top-down analysis (Figure 3.5b; $\mathrm{p}=0.033, \mathrm{~F}=5.569, \mathrm{df}=15)$. The regeneration area increased with increasing gap sizes (Figure 3.5b). 


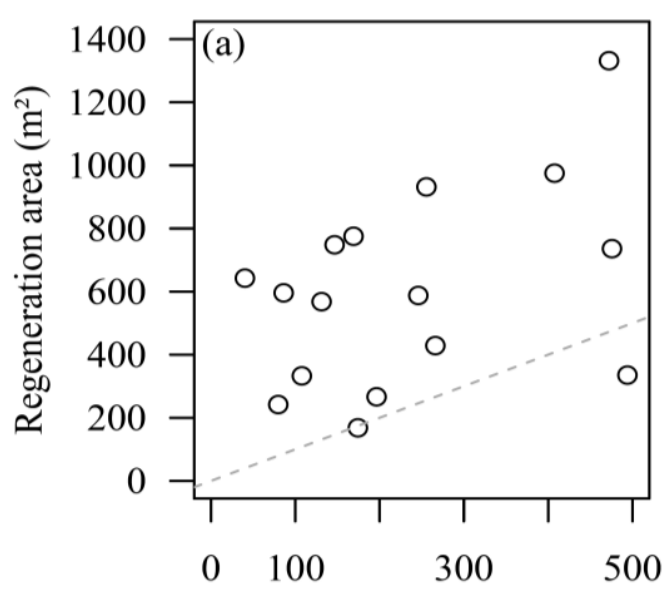

Gap size $\left(\mathrm{m}^{2}\right)$

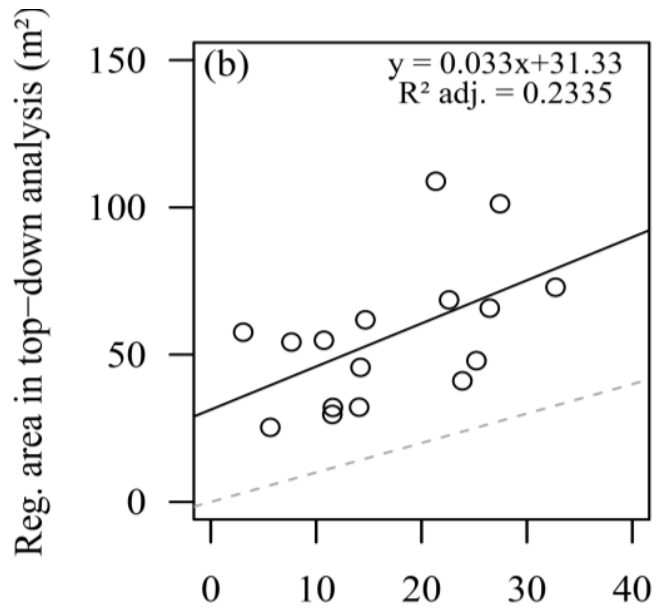

Gap size in top-down analysis $\left(\mathrm{m}^{2}\right)$

Figure 3.5: Scatterplots of regeneration area $\left(\mathrm{m}^{2}\right)$ over gap size $\left(\mathrm{m}^{2}\right)$. (a) Non-significant relationship between gap size and resulting regeneration area based on polygon analysis. (b) Significant relationship between gap size and regeneration area based on raster data in top-down analyses. The dashed grey lines mark the 1:1 relationship between both sizes.

Gap shapes varied from nearly circular (0.96) (6/36 gaps), to irregularly stretched (30/36 gaps) in the north-south $($ maximum $=2.92)$ or west-east $($ minimum $=0.30)$ direction, while both were similarly frequent (Table 3.2 ).

The maximum stand height had a range between $31.25 \mathrm{~m}$ in Kellerwald to $45.50 \mathrm{~m}$ in Rožok and the calculated maximum solar angles varied between $60.43^{\circ}$ and $65.43^{\circ}$ (Table 3.2). Given the maximum solar angle and the individual stand height for each location, minimum diameters of a hypothetical circular gap arose at which direct solar radiation could reach the forest floor in the gap. This theoretical diameter was lowest in Kellerwald with $16.45 \mathrm{~m}$ and highest in Uholka with $20.64 \mathrm{~m}$. Regarding the spatial extent in the north-south direction and stand height for light availability, the gap-ratio varied between 0.12 and 1.19 in our study, and only reached 0.50 on average (Table 3.2). 
Table 3.2: Detailed information about latitude, maximum solar angle, stand height and the theoretical, minimum diameter of a circular gap at which the solar radiation directly hits the forest floor, maximum regeneration height, sizes of regeneration areas and canopy gaps, as well as a description of the spatial extent of the canopy gaps in north-south (NS) or west-east directions (WE). Every time there are multiple values of gap area for one plot, several small gaps were summed-up in terms of canopy opening size, which then was the basis for averaging gap sizes and further analysis.

\begin{tabular}{|c|c|c|c|c|c|c|c|c|c|c|c|c|c|}
\hline \multirow{2}{*}{ Study Area } & \multirow{2}{*}{$\begin{array}{c}\text { Management } \\
\text { Type }\end{array}$} & \multirow{2}{*}{ Latitude } & \multirow{2}{*}{$\begin{array}{l}\text { Max. } \\
\text { Solar } \\
\text { Angle }\end{array}$} & \multirow{2}{*}{$\begin{array}{l}\text { Min. } \\
\text { Diameter } \\
(\mathbf{m})\end{array}$} & \multirow{2}{*}{ Plot } & \multirow{2}{*}{$\begin{array}{l}\text { Stand } \\
\text { Height } \\
\text { (m) }\end{array}$} & \multirow{2}{*}{$\begin{array}{c}\text { Canopy } \\
\operatorname{Gap}\left(\mathbf{m}^{2}\right)\end{array}$} & \multirow{2}{*}{$\begin{array}{l}\text { Gap } \\
\text { Ratio } \\
(\mathbf{d} / \mathbf{h})\end{array}$} & \multicolumn{2}{|c|}{$\begin{array}{c}\text { Max. } \\
\text { Extension } \\
\quad(\mathbf{m})\end{array}$} & \multirow{2}{*}{$\begin{array}{l}\text { Direction- } \\
\text { ratio } \\
\text { (NS/WE) }\end{array}$} & \multirow{2}{*}{$\begin{array}{c}\text { Regeneration } \\
\text { Area }\left(\mathbf{m}^{2}\right)\end{array}$} & \multirow{2}{*}{$\begin{array}{l}\text { Max. } \\
\text { Height } \\
\text { (m) }\end{array}$} \\
\hline & & & & & & & & & NS & WE & & & \\
\hline \multirow{3}{*}{$\begin{array}{l}\text { Hann. } \\
\text { Münden }\end{array}$} & \multirow{3}{*}{ Traditional } & \multirow{3}{*}{$51^{\circ}$} & \multirow{3}{*}{$62.43^{\circ}$} & \multirow{3}{*}{17.20} & 1 & 34.50 & 169.21 & 1.11 & 38.3 & 13.1 & 2.92 & 775.76 & 3.6 \\
\hline & & & & & \multirow{2}{*}{2} & \multirow{2}{*}{31.40} & 68.29 & 0.22 & 7.0 & 23.4 & 0.30 & \multirow{2}{*}{748.77} & \multirow{2}{*}{4.5} \\
\hline & & & & & & & 78.22 & 0.51 & 15.9 & 12.4 & 1.28 & & \\
\hline \multirow{8}{*}{ Reinhausen } & \multirow{8}{*}{ Traditional } & \multirow{8}{*}{$51^{\circ}$} & \multirow{8}{*}{$62.43^{\circ}$} & \multirow{8}{*}{17.13} & \multirow{7}{*}{1} & \multirow{7}{*}{32.40} & 17.10 & 0.15 & 5.0 & 6.0 & 0.83 & \multirow{7}{*}{266.71} & \multirow{7}{*}{3.9} \\
\hline & & & & & & & 36.32 & 0.21 & 6.7 & 9.6 & 0.70 & & \\
\hline & & & & & & & 11.76 & 0.18 & 5.9 & 4.0 & 1.48 & & \\
\hline & & & & & & & 17.39 & 0.17 & 5.5 & 4.4 & 1.25 & & \\
\hline & & & & & & & 56.26 & 0.43 & 13.9 & 11.6 & 1.20 & & \\
\hline & & & & & & & 31.06 & 0.25 & 8.0 & 8.8 & 0.91 & & \\
\hline & & & & & & & 26.49 & 0.13 & 4.1 & 10.1 & 0.41 & & \\
\hline & & & & & 2 & 33.20 & 107.75 & 0.58 & 19.3 & 13.0 & 1.48 & 332.87 & 3.6 \\
\hline & & & & & & & 175.27 & 0.49 & 18.4 & 20.6 & 0.89 & & \\
\hline & & & & & 1 & 37.85 & 125.62 & 0.41 & 15.7 & 13.8 & 1.14 & 335.69 & 7.5 \\
\hline & & & & & & & 193.13 & 0.82 & 31.0 & 28.4 & 1.10 & & \\
\hline Fhrogh & & $10^{\circ}$ & & & & & 41.84 & 0.17 & 6.5 & 15.6 & 0.42 & & \\
\hline Ebrach & Alternative & $49^{\circ}$ & $64.43^{\circ}$ & 18.11 & & & 26.24 & 0.12 & 4.7 & 8.0 & 0.59 & & \\
\hline & & & & & 2 & 37.84 & 54.37 & 0.19 & 7.1 & 12.0 & 0.59 & 429.08 & 8.6 \\
\hline & & & & & & & 87.74 & 0.25 & 9.6 & 20.8 & 0.46 & & \\
\hline & & & & & & & 55.98 & 0.18 & 7.0 & 14.7 & 0.48 & & \\
\hline Lübeck & Alternative & $53^{\circ}$ & $60.43^{\circ}$ & 19.33 & 1 & 33.85 & 79.65 & 0.35 & 12.0 & 12.5 & 0.96 & 242.04 & 5.5 \\
\hline
\end{tabular}


Chapter 3

\begin{tabular}{|c|c|c|c|c|c|c|c|c|c|c|c|c|c|}
\hline & & & & & 2 & 34.29 & 174.34 & 0.59 & 20.2 & 15.4 & 1.31 & 168.33 & 4.8 \\
\hline \multirow{4}{*}{ Kellerwald } & \multirow{4}{*}{ National Park } & \multirow{4}{*}{$51^{\circ}$} & \multirow{4}{*}{$62.43^{\circ}$} & \multirow{4}{*}{16.45} & 1 & 31.75 & 246.03 & 1.19 & 37.8 & 14.1 & 2.68 & 587.77 & 5.9 \\
\hline & & & & & \multirow{3}{*}{2} & \multirow{3}{*}{31.25} & 94.23 & 0.40 & 12.4 & 22.5 & 0.55 & \multirow{3}{*}{931.79} & \multirow{3}{*}{7.6} \\
\hline & & & & & & & 96.55 & 0.38 & 12.2 & 12.7 & 0.96 & & \\
\hline & & & & & & & 64.78 & 0.37 & 11.6 & 8.3 & 1.40 & & \\
\hline \multirow{2}{*}{ Hainich } & \multirow{2}{*}{ National Park } & \multirow{2}{*}{$51^{\circ}$} & \multirow{2}{*}{$62.43^{\circ}$} & \multirow{2}{*}{19.63} & 1 & 38.45 & 40.31 & 0.24 & 9.1 & 9.8 & 0.93 & 642.79 & 5.1 \\
\hline & & & & & 2 & 36.75 & 131.21 & 0.58 & 21.4 & 12.0 & 1.78 & 568.66 & 5.7 \\
\hline \multirow{7}{*}{ Rožok } & \multirow{7}{*}{$\begin{array}{c}\text { Primary } \\
\text { Forest }\end{array}$} & \multirow{7}{*}{$48^{\circ}$} & \multirow{7}{*}{$65.43^{\circ}$} & \multirow{7}{*}{20.25} & \multirow{3}{*}{1} & \multirow{3}{*}{43.75} & 112.00 & 0.48 & 20.9 & 11.9 & 1.76 & \multirow{3}{*}{975.87} & \multirow{3}{*}{4.2} \\
\hline & & & & & & & 66.60 & 0.37 & 16.1 & 10.6 & 1.52 & & \\
\hline & & & & & & & 229.04 & 0.51 & 22.2 & 14.3 & 1.55 & & \\
\hline & & & & & \multirow{4}{*}{2} & \multirow{4}{*}{44.85} & 91.22 & 0.35 & 15.6 & 17.6 & 0.89 & \multirow{4}{*}{1331.81} & \multirow{4}{*}{6.5} \\
\hline & & & & & & & 33.77 & 0.17 & 7.7 & 11.0 & 0.70 & & \\
\hline & & & & & & & 309.25 & 0.42 & 18.9 & 25.3 & 0.75 & & \\
\hline & & & & & & & 38.09 & 0.23 & 10.3 & 8.3 & 1.24 & & \\
\hline \multirow{2}{*}{ Uholka } & \multirow{2}{*}{$\begin{array}{c}\text { Primary } \\
\text { Forest }\end{array}$} & $48^{\circ}$ & $6543^{\circ}$ & 2064 & 1 & 45.50 & 86.12 & 0.39 & 17.8 & 10.7 & 1.66 & 596.19 & 5.6 \\
\hline & & 40 & 05.45 & 20.04 & 2 & 44.80 & 475.68 & 0.61 & 27.3 & 27.3 & 1.37 & 736.21 & 7.0 \\
\hline
\end{tabular}




\subsubsection{Regeneration Height in Dependency of Canopy Closure}

Depending on the position of the area under regeneration, the top-down analysis revealed the same significant pattern in height decline in total $(p=0.000, F=15,986, \mathrm{df}=6)$, for each type of management (Traditional: $\mathrm{p}=0.000, \mathrm{~F}=884.2$, $\mathrm{df}=6$; Alternative: $\mathrm{p}=0.000, \mathrm{~F}=4776, \mathrm{df}=6$; National Park: $\mathrm{p}=0.000, \mathrm{~F}=7462, \mathrm{df}=6$; Primary forest: $\mathrm{p}=0.000, \mathrm{~F}=557,9, \mathrm{df}=6$ ), and on plot level (Table 3.3). Overall, the mean height of the regeneration decreased from positions within the gap, over the five buffer zones, to under densely closed canopy, as defined above (Figure 3.6).

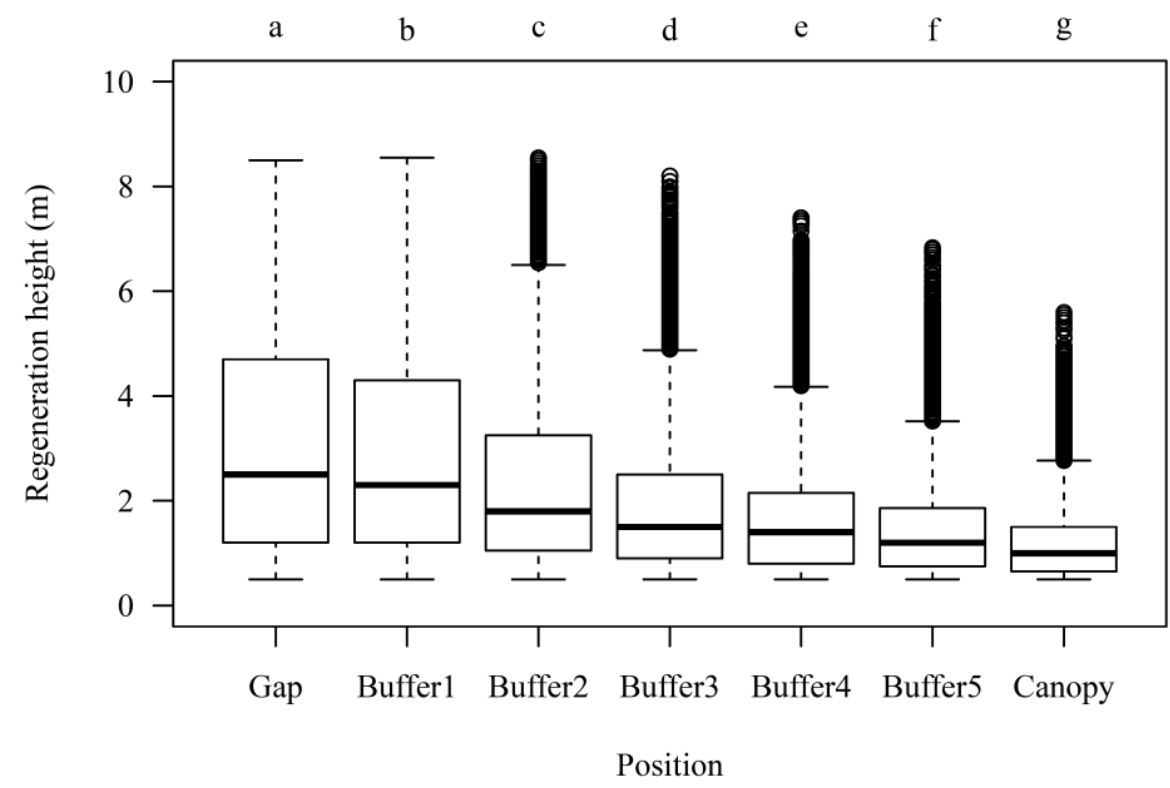

Figure 3.6: Box-whisker plots of the regeneration vegetation height $(\mathrm{m})$ in dependence of position in gap, in buffer zone (1-5 m) or under closed canopy. Different lower-case letters indicate significant differences between positions at the level of $\mathrm{p}<0.05$.

By analyzing the five buffer zones around the actual gap polygon area separately for each plot, we found a progressive decline in regeneration height from Buffer 1 (up to $1 \mathrm{~m}$ distance to the projected gap edge) to Buffer 5 (4-5 m distance to the projected gap edge; Figure 3.7).

We found the smallest decrease between buffer zones 1-3. The strongest decrease in mean regeneration height $(21 \%)$ was found between buffer zone 5 and the regeneration under the closed canopy of the neighboring stand. The differences in mean regeneration height between the outermost buffer zone 5 and the regeneration under the closed canopy were significant for all but four plots (Table 3.3). 
Table 3.3: Mean regeneration height depending on the position of the regeneration area from within-gap over transitional buffer zones to closed-canopy. Different lower-case letters indicate significant differences between positions at the level of $p<0.05$. The degrees of freedom in all statistical tests were six. Column " $p$ " lists the $p$-values that indicates the significance of the test results. The F-value in column " $F$ " indicates the value of the F-distribution used to calculate the $p$-value.

\begin{tabular}{|c|c|c|c|c|c|c|c|c|c|c|}
\hline \multirow[b]{2}{*}{ Location } & \multirow[b]{2}{*}{ Plot } & \multicolumn{9}{|c|}{ Position } \\
\hline & & Gap & Buffer1 & Buffer2 & Buffer3 & Buffer4 & Buffer5 & Canopy & $p$ & $\mathbf{F}$ \\
\hline \multirow{2}{*}{$\begin{array}{c}\text { Hann. } \\
\text { Münden }\end{array}$} & 1 & $1.17^{\mathrm{a}}$ & $1.12^{b}$ & $1.09^{c}$ & $1.12^{\mathrm{d}}$ & $1.08^{\mathrm{e}}$ & $1.08^{\mathrm{e}}$ & $1.03^{\mathrm{e}}$ & 0.000 & 28.02 \\
\hline & 2 & $1.63^{\mathrm{a}}$ & $1.39^{\mathrm{b}}$ & $1.35^{\mathrm{c}}$ & $1.24^{\mathrm{d}}$ & $1.28^{\mathrm{e}}$ & $1.44^{\mathrm{e}}$ & $1.15^{\mathrm{f}}$ & 0.000 & 358.1 \\
\hline \multirow{2}{*}{ Reinhausen } & 1 & $1.89^{\mathrm{a}}$ & $1.44^{\mathrm{b}}$ & $1.43^{\mathrm{b}}$ & $1.34^{\mathrm{c}}$ & $1.09^{\mathrm{d}}$ & $0.99^{\mathrm{e}}$ & $0.82^{\mathrm{f}}$ & 0.000 & 906.4 \\
\hline & 2 & $1.34^{\mathrm{a}}$ & $1.28^{\mathrm{b}}$ & $1.18^{\mathrm{c}}$ & $1.18^{\mathrm{c}}$ & $1.14^{\mathrm{c}}$ & $1.24^{\mathrm{a}}$ & $0.79^{d}$ & 0.000 & 214.4 \\
\hline \multirow{2}{*}{ Lübeck } & 1 & $2.38^{\mathrm{a}}$ & $1.87^{\mathrm{b}}$ & $1.53^{c}$ & $1.24^{\mathrm{d}}$ & $0.98^{\mathrm{e}}$ & $1.20^{\text {ef }}$ & $1.08^{\mathrm{f}}$ & 0.000 & 1730 \\
\hline & 2 & $1.67^{\mathrm{a}}$ & $1.45^{\mathrm{b}}$ & $1.45^{b}$ & $1.43^{\mathrm{b}}$ & $1.34^{\mathrm{c}}$ & $1.09^{\mathrm{d}}$ & $0.80^{\mathrm{e}}$ & 0.000 & 450.9 \\
\hline \multirow{2}{*}{ Ebrach } & 1 & $5.13^{\mathrm{a}}$ & $4.74^{b}$ & $4.59^{c}$ & $4.34^{\mathrm{d}}$ & $3.70^{\mathrm{e}}$ & $3.20^{\mathrm{f}}$ & $1.25^{\mathrm{g}}$ & 0.000 & 1510 \\
\hline & 2 & $5.54^{\mathrm{a}}$ & $5.09^{\mathrm{b}}$ & $4.61^{c}$ & $3.51^{\mathrm{d}}$ & $1.73^{\mathrm{e}}$ & $0.73^{\mathrm{f}}$ & $0.57^{\mathrm{f}}$ & 0.000 & 1035 \\
\hline \multirow{2}{*}{ Hainich } & 1 & $2.63^{a}$ & $1.78^{b}$ & $1.68^{c}$ & $1.57^{\mathrm{d}}$ & $1.32^{\mathrm{e}}$ & $1.02^{\mathrm{f}}$ & $0.82^{\mathrm{g}}$ & 0.000 & 1237 \\
\hline & 2 & $2.90^{\mathrm{a}}$ & $2.25^{\mathrm{b}}$ & $1.99^{c}$ & $1.68^{\mathrm{d}}$ & $1.15^{\mathrm{e}}$ & $1.09^{\mathrm{e}}$ & $0.99^{\mathrm{e}}$ & 0.000 & 1370 \\
\hline \multirow{2}{*}{ Kellerwald } & 1 & $4.17^{\mathrm{a}}$ & $3.63^{b}$ & $3.18^{c}$ & $2.79^{\mathrm{d}}$ & $2.64^{\mathrm{e}}$ & $2.29^{\mathrm{f}}$ & $1.76^{\mathrm{g}}$ & 0.000 & 3280 \\
\hline & 2 & $5.41^{a}$ & $4.44^{b}$ & $4.09^{c}$ & $3.79^{\mathrm{d}}$ & $2.99^{\mathrm{e}}$ & $2.95^{\mathrm{e}}$ & $1.46^{\mathrm{f}}$ & 0.000 & 3439 \\
\hline \multirow[b]{2}{*}{ Rožok } & 1 & $1.20^{\mathrm{a}}$ & $1.33^{b}$ & $1.37^{\mathrm{c}}$ & $1.35^{\mathrm{bc}}$ & $1.29^{\mathrm{d}}$ & $1.18^{\mathrm{a}}$ & $1.02^{\mathrm{e}}$ & 0.000 & 169.9 \\
\hline & 2 & $1.21^{\mathrm{a}}$ & $1.41^{\mathrm{b}}$ & $1.45^{c}$ & $1.44^{\mathrm{cd}}$ & $1.46^{\mathrm{c}}$ & $1.29^{\mathrm{e}}$ & $1.16^{\mathrm{f}}$ & 0.000 & 493 \\
\hline \multirow{2}{*}{ Uholka } & 1 & $2.21^{\mathrm{a}}$ & $1.69^{b}$ & $1.49^{c}$ & $1.41^{\mathrm{d}}$ & $1.42^{\mathrm{d}}$ & $1.31^{\mathrm{e}}$ & $1.24^{\mathrm{f}}$ & 0.000 & 1119 \\
\hline & 2 & $2.99^{\mathrm{a}}$ & $2.76^{\mathrm{b}}$ & $2.56^{\mathrm{c}}$ & $2.61^{c}$ & $2.49^{\mathrm{c}}$ & $2.55^{\mathrm{c}}$ & $2.03^{\mathrm{d}}$ & 0.000 & 167.4 \\
\hline
\end{tabular}




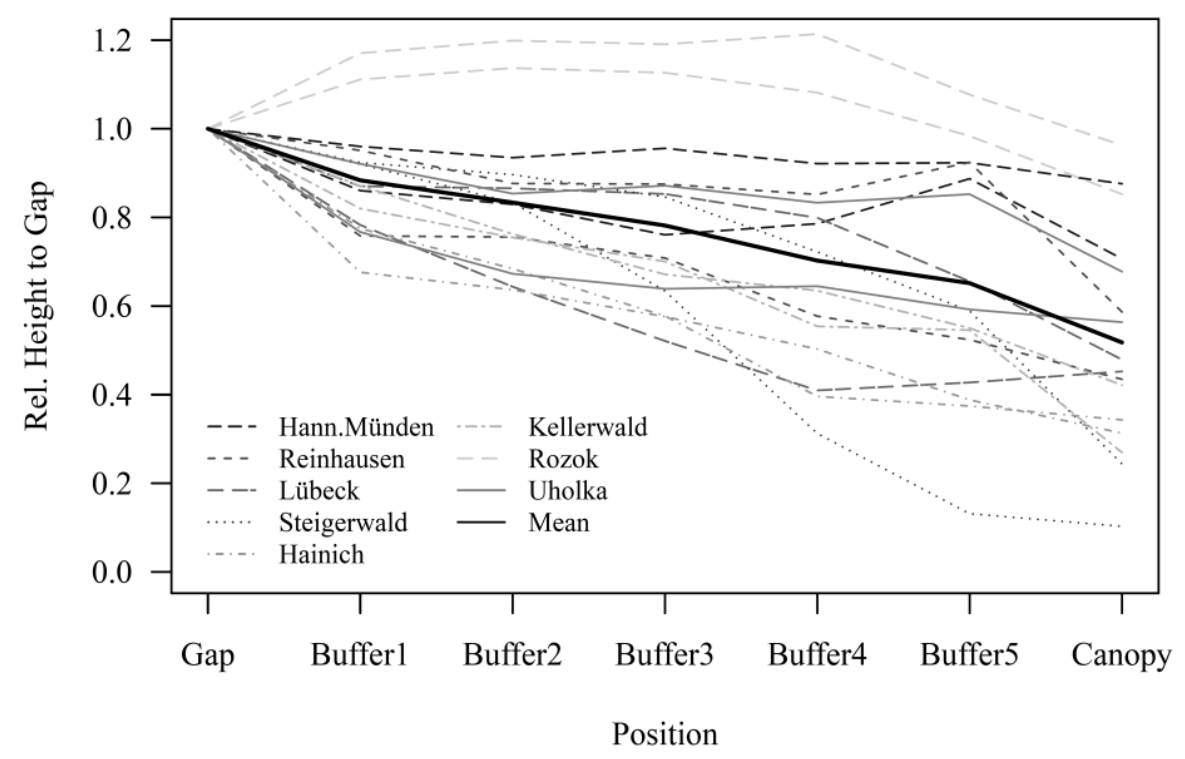

Figure 3.7: The different lines illustrate the mean height development of the regeneration relative to height in gap measured for seven classes; Gap = heights within the gap polygon; Buffer $1-5=$ subsequent $1 \mathrm{~m}$ buffer zones around the gap polygon; Canopy = all remaining heights under the canopy. Each line represents one of the 16 study plots; the solid black line shows the mean height decrease of all plots together.

\subsubsection{Spatial Distribution Pattern of Regeneration Areas}

There was no uniform pattern in the offset or offset direction of the regeneration patch centers relative to the centers of the gaps. However, the majorities of patch centers were located near the center of the projected canopy gaps (Figure 3.8a). The mean offset $(-1.7 / 0.2)$ confirmed the proximity to the gap center. The mean horizontal offset distance between the gap center and the center of the regeneration patch was $7.92 \mathrm{~m}$ and varied between $0.5 \mathrm{~m}$ and $25.04 \mathrm{~m}$. 


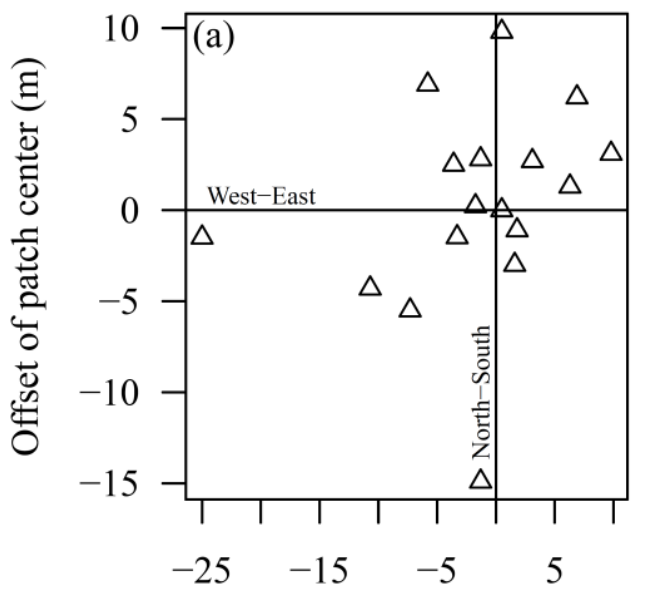

Offset of patch center $(\mathrm{m})$

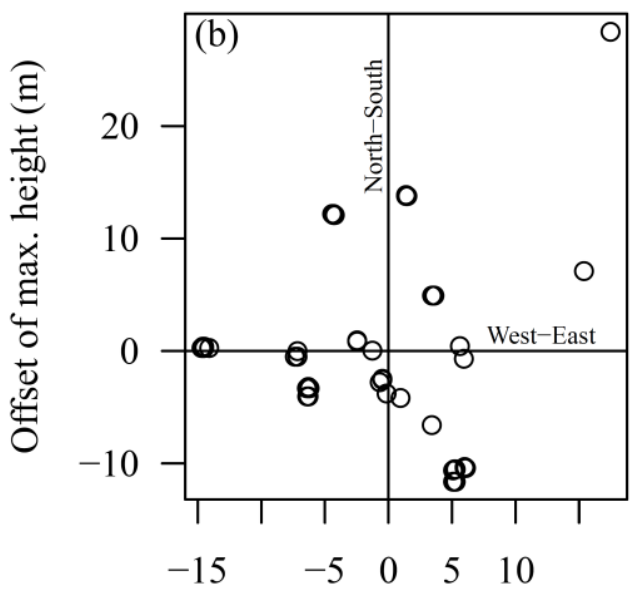

Offset of max. height (m)

Figure 3.8: Horizontal shift (a) of the regeneration patch center relative to the center of the canopy opening $(0 / 0)$, respectively and (b) horizontal shift of the maximum height within the regeneration patch relative to the center of the regeneration patch $(0 / 0)$, respectively. Open triangles mark the position $\{x / y\}$ of the regeneration patch center (a) and open circles mark the maximum height within the patch (b). The point $(0 / 0)$ in the two-dimensional coordinate system is equivalent to the projected center of the canopy gap (a) or the center of the regeneration patch (b).

Regeneration heights differed significantly within the patch polygons. The maximum height was mainly not measured directly in the projected gap center, but showed an average offset of $10.07 \mathrm{~m}$ between maximum height and patch center (Figure 3.8b). This offset varied between $2.5 \mathrm{~m}$ and $33.34 \mathrm{~m}$. Even though the mean regeneration height showed significant differences within the regeneration patch polygon, the mean height values varied only between $1.38 \mathrm{~m}$ (minimum at the maximum distance from the gap center) and $2.23 \mathrm{~m}$ (maximum at a distance of about $30 \%$ from the center). In no case, the maximum height was located at the edge or directly in the center of the regeneration patch area. 


\subsection{Discussion}

\subsubsection{Light Availability}

The fraction of direct light that actually reaches the forest floor depends on three different fundamental aspects: (i) the characteristics describing the canopy gap, such as size, shape and orientation, (ii) height and canopy architecture of gap-bordering trees, and (iii) the geographical location of the forest stand (Malcolm et al. 2001, Messier 1996).

Many studies reported an average gap size in temperate forests of less than $1000 \mathrm{~m}^{2}$, caused by the death of one or several trees, while larger gaps are rather rare (Drößler and von Lüpke 2005). Larger gaps result in drastically changed conditions in the forest ecosystem and a comparison with smaller treefall-gaps becomes hampered (Schliemann and Bockheim 2011, Yamamoto 1992, Coates 2000). Often, $1000 \mathrm{~m}^{2}$ is thus specified as maximum gap size (critical size) to be considered in gap studies. Yamamoto $(1992,2000)$ reported a mean gap size for temperate forests of $30-140 \mathrm{~m}^{2}$, while an average contribution of gaps to the total forest area in beech-dominated forests of 3-19\% is reported in the literature (Feldmann et al. 2018). Gaps larger than $400 \mathrm{~m}^{2}$ were considered rare events (Feldmann et al. 2018, Drößler and von Lüpke 2005, Yamamoto 1992). In our study, mean gap size was $234.31 \mathrm{~m}^{2}$, which is similar to mean gap size of $261 \mathrm{~m}^{2}$ recorded for the primary beech forest Kyjov (Feldmann et al. 2018). The smallest single gap $\left(12 \mathrm{~m}^{2}\right)$ was recorded in Reinhausen and the largest gap reached $476 \mathrm{~m}^{2}$ in the primary forest of Uholka. We found no significant differences in gap size of naturally and artificially created gaps caused by logging in the managed forests.

Gap size, however, is just one important attribute when it comes to light availability. For example, a long, narrow and north-south oriented gap may allow as much direct radiation as a smaller circular or elliptically shaped gap (Schliemann and Bockheim 2011). Earlier studies showed that irregularly shaped gaps receive considerably less direct radiation than circular gaps of the same size (Muscolo et al. 2014). Here, we described the shape using the direction-ratio (Table 3.2), which is the ratio of the maximum north-south to westeast extension. The gaps in our study were mainly stretched or elliptical rather than circular in shape, which affects the amount of incoming direct light. This is crucial as the low solar elevation angles in northern latitudes and the course of the sun result in a drastically limited amount of direct light for narrow gaps orientated west to east. In northsouth oriented gaps, the probability of direct radiation on the forest floor was therefore much higher. Another important factor was stand height. The taller the edge trees were, 
the lower the probability of direct solar radiation in a gap of a given size (Figure 3.3). In our case, when comparing the maximal spatial extent of the canopy gaps and the theoretical diameter required for receiving direct light through the actual gap opening, direct sunlight could reach the forest floor only in 10 out of the $36(28 \%)$ gaps.

According to Malcom et al. (2001) light-demanding species such as Scots pine (Pinus sylvestris L.), Lodgepole pine (Pinus contorta var latifolia Engelm. Dougl. ex Loud.) and larches (Larix sp.) need a ratio of gap diameter to stand height larger than 2.0 to regenerate. In contrast, intermediate shade-tolerant species such as Douglas fir (Pseudotsuga menziesii (Mirbel) Franco), Sitka spruce (Picea sitchensis (Bong.) Carrière) and Corsican pine (Pinus nigra A.) require gap d/h-ratios between 1.0 and 2.0. Even though gaps with a gap-ratio smaller than 1.0 allow germination for most of the tree species, the low light values in such small gaps permit successful establishment of regeneration for a few shade-tolerant species, e.g., for beech, only (Malcolm et al. 2001, Emborg 1996). Gaps with a ratio less than 0.5 are not appropriate for the establishment of regeneration of any species (Zhu et al. 2003). These assumptions are, however, not in line with the results presented here. We found established beech regeneration in small gaps with a $\mathrm{d} / \mathrm{h}$-ratio as low as 0.12 . This highlights that diffuse radiation is clearly sufficient to enable natural regeneration of European beech to establish in low light conditions. The finding that the regeneration patch area showed no increase with increasing $\mathrm{d} / \mathrm{h}$-ratio (Table 3.2 ) provides further evidence for the independency of early tree regeneration from direct radiation. Thus, the results not only suggest independence of tree regeneration from direct light availability but also confirm once more the high shade-tolerance of European beech compared to other tree species (Petriţan 2007, 2009).

\subsubsection{Spatial Distribution Patterns of Regeneration Height}

The availability of light under closed canopies is drastically reduced compared to openland conditions and increases significantly in gaps (Canham et al. 1990, 1989). It was shown that even treefall gaps with areas between $20-300 \mathrm{~m}^{2}$, as mainly found here, are sufficient to significantly improve the availability of photosynthetic active radiation in the understory (Canham et al. 1990, Coates 2000). However, we did not find a significant relationship between mean sizes of gap and regeneration area when concerning regeneration patch polygons and gap polygons (Figure 3.5a). Anyhow, we did find a significant relationship between the size of gap openings and the regeneration area, when the analysis was based on the raster data, which represented a more general subsection of 
the whole plots compared to the delineated polygons (Figure 3.5b). Thus, our first hypothesis could only be partially confirmed. One possible explanation is the underlying methodology. The comparison between gap size and regeneration patch area was based on a small sample size of 16 forest plots, which were limited to an extent of $50 \times 50 \mathrm{~m}$. Furthermore, exact gap age was not known but was only approximated based on the number of visible internodes of the regeneration plants. It was therefore not possible to determine how both the size and the shape of the gaps had changed over time. However, our analyses of buffer zones indicated that the actual regeneration area was generally larger than the associated canopy gap (Figure 3.6). This emphasizes that the ecological impact of a canopy gap is not limited to the vertically projected area only.

Several studies showed a general increase in height growth of saplings with increased light availability (Canham 1989, Coates 2000, Malcolm et al. 2001, Beaudet and Messier 1998, Brokaw and Busing 2000). The adjacent forest area, the penumbral zone (Kolari et al. 2006), experiences an increase in light availability due to the canopy opening as well (Brown 1996). Using an approach based on buffer zones, which may represent such a penumbral zone, we could confirm our second hypothesis. We found that the mean regeneration height was highest within the gap polygon and declined significantly from the gap edges to the closed canopy (Figures 3.6 and 3.7). The significant differences between mean regeneration heights in the gap, the adjacent buffer zone and the neighboring "closed" stand validated the general assumption that regeneration was not only promoted directly in the gap, but also in adjacent parts of the projected gap area. We observed the same pattern of height decline in each of the four management types. Because of significant differences in mean height between regeneration in the outermost buffer zone 5 and the regeneration under closed canopy in at least 12 out of 16 study plots (Table 3.3), it could be assumed that the penumbral zone had a width of at least $5 \mathrm{~m}$ in the investigated managed and unmanaged beech-dominated forests in Central Europe.

The importance of diffuse light for the establishment of beech regeneration may also be the reason why we had to reject hypothesis (c) that suggested an offset of the regeneration patch center towards north. Instead, the regeneration patch centers were located around the gap centers (Figure 3.8a). This finding is in line with the results of Coates (2000) and Malcolm et al. (2001) who also found no significant differences between sapling growth in sunny (north edge) and shady (south edge) gap positions for other rather shade-tolerant tree species like spruce (Picea sp.), western hemlock (Tsuga heterophylla), and some fir 
species (Abies sp.). For more light demanding species, however, contrasting findings have been reported (Canham et al. 1990, Runkle 1981). The hypothesized relationship between position and height may only occur in gaps with specific dimensions, where light levels are less uniform across the gap area. For example, Coates (2002) found differences in sapling growth of different conifer seedlings from shady southern to sunny northern ends of the gaps, especially in gaps with an area of $300 \mathrm{~m}^{2}$ or more. Hence, it is not surprising that we could not observe a significant shift of the center of the regeneration patch or the maximum height within the patch in any compass direction (Figure 3.8a,b).

Beside the well-known facts that canopy edge trees do not only respond to changed light regime at the edge of canopy gaps but that they also influence the light availability in the gap themselves (Schröter et al. 2012, Seidel et al. 2016), they affect the belowground resources (Wagner et al. 2009). Trenching experiments have shown the strong impact of mature trees on regeneration performance by belowground competition (Riegel et al. 1992, Ammer 2002, Petriţan et al. 2011). Height growth of beech seedlings was successfully explained by a combination of above- and belowground resource availability (Wagner et al. 2009). The lowest amount of root competition induced from the edge trees and a considerable high amount of light availability can be found in the gap center, which suggests good regeneration performance around the gap center. However, in the gap center other factors such as herbaceous competition may also be high (Diaci et al. 2012, Modrý et al. 2004). This may explain the offset between maximum height and regeneration patch center found in our study suggesting the rejection of our fourth hypothesis. Actually, the maximum height measurements within the regeneration patches were not observed directly in the center, but slightly offset between center and the outer limit of the regeneration patch. Thus, in six out of 16 plots the maximum height of the whole regeneration patch was located in one of the buffer zones and not within the boundaries of the gap polygon. The minimum regeneration heights (mean and in total) were found at the outer edges of the regeneration patches, which may confirm the high competition pressure exerted by the neighboring mature trees. This results in the highest regeneration heights of beech to be found in areas with intermediate light levels, where beech is most competitive (Diaci et al. 2012, Rozenbergar et al. 2007).

All tested hypotheses showed no differences between the four types of management. This shows that after gap creation (be it natural or artificial) regeneration development is 
driven by management independent factors, presumably most strongly by the abiotic growth site conditions.

\subsection{Conclusions}

Even though it is an undisputed fact that the dynamics of natural regeneration are influenced by overstory dynamics such as gap-opening and successive re-closure, these relationships are not easy to quantify. In this study, we found indications for a promotion of beech regeneration beyond gap borders. The fact that regeneration had not only established within the projected gap but also outside of this area confirms that gaps also promote regeneration in parts of the forest stand adjacent to the gap, in the penumbral zone.

A spatial offset northward as reported for several tree species with an assumed lower shade tolerance compared to beech (for example: Sugar maple (Acer saccharum Mrsh.), Western red cedar (Thuja plicata Donn. ex D. Don), Lodgepole pine (Coates 2000, 2002, Canham 1988, 1989), could not be confirmed for the shade-tolerant European beech.

Furthermore, it was possible to detect a general pattern of spatial distribution of beech regeneration heights, which seems to be independent of management.

Altogether, these results confirm the importance of canopy gaps and gap dynamics for the establishment and development of natural regeneration, in this case for European beech. We could also show a great potential for regeneration studies based on terrestrial laser scanning. The approach enabled spatial relationships between the overstory and understory to be addressed in a unique way and with great spatial resolution.

Author Contributions: Conceptualization, M.S., K.W., D.S., C.A. and P.A.; data curation, M.S. and K.W.; formal analysis, M.S., K.W., D.S. and P.A.; funding acquisition, D.S., C.A. and P.A.; investigation, M.S., K.W. and M.K.; methodology, M.S., K.W., D.S. and P.A.; project administration, D.S., C.A. and P.A.; supervision, D.S., C.A. and P.A.; writing—original draft, M.S.; writing—review and editing, M.S., D.S., C.A., J.S. and P.A.

Funding: The Dr. Erich Ritter Foundation (T0021/29427/2017) is greatly acknowledged for funding this work. The German Research Foundation through grant SE2383/5-1 also funded part of this work.

Acknowledgments: We thank all persons that gave us access to the forest districts they are responsible for and helped us in selection of suitable plots: Axel Pampe, Thomas SchmidtLangenhorst, Sabine Steinhoff, Knut Sturm, Torsten Welle, Manfred Großmann, Manfred Bauer, 
Achim Frede, Bernd Schock, Ulrich Mergner, Martin Schafhirt, Peter Jaloviar, and Vasyl Lavnyy. Permits for accessing the primary forests and fieldwork were issued by the responsible environmental protection office in Presov and administration of "Poloniny National park" for Slovakia and Carpathian Biosphere Reserve for Ukraine.

Conflicts of Interest: The authors declare no conflict of interest. The funders had no role in the design of the study; in the collection, analyses, or interpretation of data; in the writing of the manuscript, or in the decision to publish the results.

\subsection{References}

Ammer, C. (2002): Response of Fagus sylvatica seedlings to root trenching overstory Picea abies. Scandinavian Journal of Forest Research, 17, 408-416.

Beaudet, M., Messier, C. (1998): Growth and morphological responses of yellow birch, sugar maple and beech seedlings growing under a natural light gradient. Canadian Journal of Forest Research, 28, 1007-1015.

Brokaw, N.V.L. (1982): The definition of treefall gap and its effect on measures of forest dynamics. Biotropica, 11, 158-160.

Brokaw, N.V.L., Busing, R.T. (2000): Niche versus chance and tree diversity in forest gaps. Tree, $15,183-188$.

Brown, N. (1996): A gradient of seedling growth from the center of a tropical rain forest canopy gap. Forest Ecology and Management, 82, 239-244.

Canham, C.D. (1988): Growth and canopy architecture of shade-tolerant trees: Response to canopy gaps. Ecology, 69, 786-795.

Canham, C.D. (1989): Different responses to gaps among shade-tolerant tree species. Ecology, $70,548-550$.

Canham, C.D., Denslow, J.S., Platt, W.J., Runkle, J.R., Spies, T.A., White, P.S. (1990): Light regimes beneath closed canopies and treefall-gaps in temperate and tropical forests. Canadian Journal of Forest Research, 20, 620-631.

Coates, K.D. (2000): Conifer seedling response to northern temperate forest gaps. Forest Ecology and Management, 127, 249-269.

Coates, K.D. (2002): Tree recruitment in gaps of various size, clearcuts and undisturbed mixed forest of interior British Columbia, Canada. Forest Ecology and Management, 155, 387 398.

Collet, C., Lanter, O., Pardos, M. (2002): Effects of canopy opening on the morphology and anatomy of naturally regenerated beech seedlings. Trees, 16, 291-298. 
De Lima, R.A.F. (2005): Gap size measurement: The proposal of a new field method. Forest Ecology and Management, 214, 413-419.

Diaci, J., Adamic, T., Rozman, A. (2012): Gap recruitment and partitioning in an old-growth beech forest of the Dinaric Mountains: Influences of light regime, herb competition and browsing. Forest Ecology and Management, 285, 20-28.

Drößler, L., and von Lüpke, B. (2005): Canopy gaps in two virgin beech forest reserves in Slovakia. Journal of Forest Science, 51, 446-457.

Ehbrecht, M., Schall, P., Juchheim, J., Ammer, C., Seidel, D. (2016): Effective number of layers: A new measure for quantifying three-dimensional stand structure based on sampling with terrestrial LiDAR. Forest Ecology and Management, 380, 212-223.

Emborg, J. (1998): Understorey light conditions and regeneration with respect to the structural dynamics of a near-natural temperate deciduous forest in Denmark. Forest Ecology and Management, 106, 83-95.

EUFORGEN (2009): Distribution Map of Beech (Fagus Sylvatica). 2009. Available online: http://www.euforgen.de (accessed on 28. May2018).

Feldmann, E., Drößler, L., Hauck, M., Kucbel, S., Pichler, V., Leuschner, C. (2018): Canopy gap dynamics and tree understory release in a virgin beech forest, Slovakian Carpathians. Forest Ecology and Management, 415, 38-46.

Green, P.T. (1996): Canopy gaps in rain forest on Christmas Island, Indian Ocean: Size distribution and methods of measurement. Journal of Tropical Ecology, 12, 427-434.

Gustafsson, L., Baker, S.C., Bauhus, J., Beese, W.J., Brodie, A., Kouki, J., Lindenmayer, D.B., Löhmus, A., Pastur, G.M., Messier, C., et al. (2012): Retention forestry to maintain multifunctional forests: A world perspective. BioScience, 62, 633-645.

Hijmans, R.J. (2017): Raster: Geographic Data Analysis and Modeling. R Package Version 2.67. Available online: https://CRAN.R-project.org/package=raster (accessed on 20. February 2019).

Hobi, M.L., Ginzler, C., Commarmot, B., Bugmann, H. (2015): Gap pattern of the largest primeval beech forest of Europe revealed by remote sensing. Ecosphere, 6, 1-15.

Hobi, M.L., Commarmot, B., Bugmann, H. (2015): Pattern and process in the largest primeval beech forest of Europe (Ukrainian Carpathians). Journal of Vegetation Science, 26, 323336.

Kneeshaw, D.D., and Bergeron, Y. (1998): Canopy gap characteristics and tree replacement in the southeastern boreal forest. Ecology, 79, 783-794. 
Kolari, P., Pumpanen, J., Kulmala, L., Ilvesniemi, H., Nikinmaa, E., Grönholm, T., Hari, P. (2006): Forest floor vegetation plays an important role in photosynthetic production of boreal forests. Forest Ecology and Management, 221, 241-248.

Koukoulas, S., Blackburn, G.A. (2004): Quantifying the spatial properties of forest canopy gaps using LiDAR imagery and GIS. International Journal of Remote Sensing, 25, 3049-3072.

Malcolm, D.C., Mason, W.L., Clarke, G.C. (2001): The transformation of conifer forests in Britain-Regeneration, gap size and silvicultural systems. Forest Ecology and Management, 151, 7-23.

Messier, C. (1996): Managing light and understory vegetation in boreal and temperate broadleafconifer forests. In Silviculture of Temperate and Boreal Broadleaf-Conifer Mixtures; Land Management Handbook; Comeau, P.G., Thomas, K.D., Eds.; BC Ministry of Forests: Victoria, BC, Canada, pp. 59-81.

Meyer, P., Tabaku, T., von Lüpke, B. (2003): Die Struktur albanischer Rotbuchen-UrwälderAbleitungen für eine naturnahe Buchenwirtschaft. Forstwissenschaftliches Centralblatt, $122,47-58$.

Meyer, P., Ammer, C. (2019): 6 Anthropogene Störungen, 6.1 Waldnutzungen. In Störungsökologie; Wohlgemuth, T., Jentsch, A., Seidl, R., Eds.; UTB GmbH Stuttgart, pp. 273-303.

Mitamura, M., Yamamura, Y., Nakano, T. (2008): Large-scale canopy opening causes decreased photosynthesis in the saplings of shade-tolerant conifer, Abies veitchii. Tree Physiology, 29, 137-145.

Modrý, M., Hubený, D., Rejšek, K. (2004): Differential response of naturally regenerated European shade tolerant tree species to soil type and light availability. Forest Ecology and Management, 188, 185-195.

Muscolo, A., Bagnato, S., Sidari, M., Mercurio, R. (2014): A review of the roles of forest canopy gaps. Journal of Forest Research, 25, 725-736.

Nagel, T.A., Zenner, E., Brang, P. (2013): Research in Old-Growth Forests and Forest Reserves: Implications for Integrated Forest Management. Integrative Approaches as an Opportunity for the Conservation of Forest Biodiversity; European Forest Institute: Freiburg, Germany, 2013; pp. 44-50. 
NLF (Niedersächsische Landesforsten): Entscheidungshilfen zur Behandlung und Entwicklung von Buchenbeständen. Available online: https://www.nwfva.de/fileadmin/user_upload/Verwaltung/Publikationen/Merkblaetter/Bu_Nds_Entsche idungshilfen_zur_Behandlung_und_Entwicklung_von_Buchenbestaenden.pdf (accessed on 30. July 2018).

Petriţan, A.M., von Lüpke, B., Petriţan, I.C. (2007): Effects of shade on growth and mortality of maple (Acer pseudoplatanus), ash (Fraxinus excelsior) and beech (Fagus sylvatica) saplings. Forestry, 80, 397-412.

Petriţan, A.M., von Lüpke, B., Petriţan, I.C. (2009): Influence of light availability on growth, leaf morphology and plant architecture of beech (Fagus sylvatica L.), maple (Acer pseudoplatanus L.) and ash (Fraxinus excelsior L.) saplings. European Journal of Forest Research, 128, 61-74.

Petriţan, I.C., von Lüpke, B., Petriţan, A.M. (2011): Effects of root trenching of overstorey Norway spruce (Picea abies) on growth and biomass of underplanted beech (Fagus sylvatica) and Douglas fir (Pseudotsuga menziesii) saplings. European Journal of Forest Research, 130, 813-828.

R Core Team (2017): R: A Language and Environment for Statistical Computing; R Foundation for Statistical Computing: Vienna, Austria. Available online: https://www.R-project.org/ (accessed on 20. February 2019).

Riegel, G.M., Miller, R.F., Krueger, W.C. (1992): Competition for resources between understory vegetation and overstory Pinus ponderosa in northeastern Oregon. Ecological Applications, 2, 71-85.

Roussel, J.R., Auty, D. (2019): lidR: Airborne LiDAR Data Manipulation and Visualization for Forestry Applications. R Package Version 2.0.0. Available online: https://CRAN.Rproject.org/package=lidR (accessed on 20. February 2019).

Rozenbergar, D., Mikac, S., Anic, I., Diaci, J. (2007): Gap regeneration patterns in relationship to light heterogeneity in two old-growth beech-fir forest reserves in South East Europe. Forestry, 80, 431-443.

Runkle, J.R. (1981): Gap regeneration in some old-growth forests of the eastern United States. Ecology, 62, 1041-1051.

Runkle, J.R. (1982): Patterns of disturbance in some old-growth mesic forests of Eastern North America. Ecology, 63, 1533-1546.

Runkle, J.R. (1992): Guidelines and Sample Protocol for Sampling Forest Gaps; General Technical Report PNW-GTR-283; Forest Service: Washington, DC, USA. 
Schliemann, S.A., Bockheim, J.G. (2011): Methods for studying treefall gaps: A review. Forest Ecology and Management, 261, 1143-1151.

Schröter, M., Härdtle, W., von Oheimb, G. (2012): Crown plasticity and neighborhood interactions of European beech (Fagus sylvatica L.) in an old-growth forest. European Journal of Forest Research, 131, 787-798.

Seidel, D., Beyer, F., Hertel, D., Fleck, S., Leuschner, C. (2011): 3D-laser scanning: A nondestructive method for studying above-ground biomass and growth of juvenile trees. Agricultural and Forest Meteorology, 151, 1305-1311.

Seidel, D., Ammer, C., Puettmann, K. (2015): Describing forest canopy gaps efficiently, accurately, and objectively: New prospects through the use of terrestrial laser scanning. Agricultural and Forest Meteorology, 213, 23-32.

Seidel, D., Ruzicka, K.J., Puettmann, K. (2016): Canopy gaps affect the shape of Douglas-fir crowns in the western Cascades, Oregon. Forest Ecology and Management, 363, 31-38.

Stiers, M., Willim, K., Seidel, D., Ehbrecht, M., Kabal, M., Ammer, C., Annighöfer, P. (2018): A quantitative comparison of the structural complexity of managed, lately unmanaged and primary European beech (Fagus sylvatica L.) forests. Forest Ecology and Management, 430, 357-365.

Wagner, S., Madsen, P., Ammer, C. (2009): Evaluation of different approaches for modelling individual tree seedling height growth. Trees, 23, 701-715.

Wagner, S., Fischer, H., Huth, F. (2011): Canopy effects on vegetation caused by harvesting and regeneration treatments. European Journal of Forest Research, 130, 17-40.

Willim, K., Stiers, M., Annighöfer, P., Ammer, C., Ehbrecht, M., Kabal, M., Stillhard, J., Seidel, D. (2019): Assessing understory complexity in beech-dominated Forests (Fagus sylvatica L.)-from managed to primary forests. Sensors, 19, 1684.

Yamamoto, S-I. (1992): The gap theory in forest dynamics. Botanical Magazine, 105, 375-383.

Yamamoto, S-I. (2000) Forest gap dynamics and tree regeneration. Journal of Forest Research, 5, 223-229.

Zhu, J., Matsuzaki, T., Lee, F., Gonda, Y. (2003): Effect of gap size created by thinning on seedling emergency, survival and establishment in a coastal pine forest. Forest Ecology and Management, 182, 339-354. 
Chapter 4

Quantifying the target state of forest stands managed with the continuous cover approach - revisiting Möller's "Dauerwald" concept after 100 years

This chapter is published as research article in Trees, Forests and People 1 (2020), 100004, Elsevier. 


\title{
Quantifying the target state of forest stands managed with the continuous cover approach - revisiting Möller's "Dauerwald" concept after 100 years
}

\author{
Melissa Stiers $^{1 *}$, Peter Annighöfer ${ }^{2}$, Dominik Seidel ${ }^{1}$, Katharina Willim ${ }^{1}$, Liane \\ Neudam $^{1}$ and Christian Ammer ${ }^{1}$
}

${ }^{1}$ Silviculture and Forest Ecology of the Temperate Zones, Faculty of Forest Sciences, University of Göttingen, Büsgenweg 1, 37077 Göttingen, Germany

${ }^{2}$ Forest and Agroforest Systems, Technical University of Munich (TUM), Hans-Carl-von-Carlowitz-Platz 2, 85354 Freising, Germany

*Correspondence: melissa.stiers@forst.uni-goettingen.de

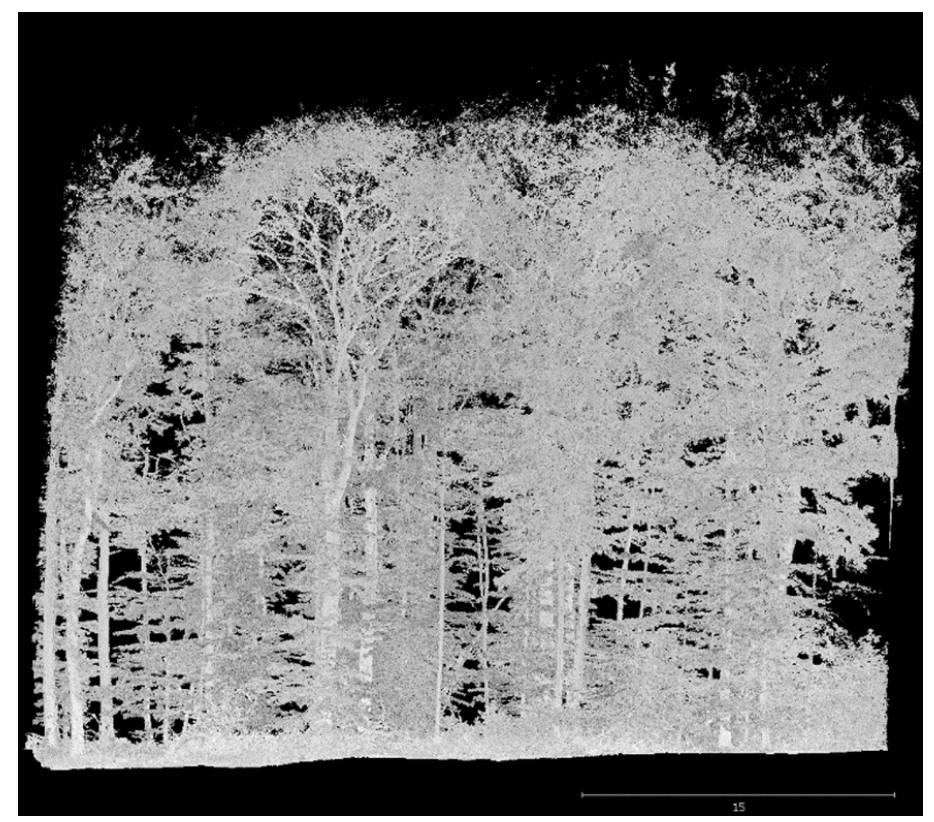

Melissa Stiers has contributed significantly to the study concept and design, and planned data acquisition, collected, and evaluated the data. Melissa Stiers was responsible for literature research, statistical data analysis, results and writing the manuscript. Christian Ammer, Peter Annighöfer and Dominik Seidel supervised the data analyses and together with Liane Neudam and Katharina Willim, they assisted, reviewed and edited the article draft. 


\begin{abstract}
Continuous cover forestry is often considered a management alternative to age-class forestry, in closer compliance with economic as well as societal demands. It is further thought to provide forest stands of high stability and resilience under conditions of climate change. The guiding principle for the stand structure of continuous cover forestry systems is to create managed forest stands that are multi-layered and hence of high structural diversity. Past studies of both these characteristics have been mostly qualitative. Here we used data from terrestrial laser scanning (TLS) to quantify differences in stand structure between forests managed for decades according to the continuous cover concept and forests managed otherwise. We found that the vertical distribution of plant material in the continuous cover stands was relatively homogeneous and similar to the vertical distribution found in primary European beech forests. We also found that the structural complexity of continuous cover forests was significantly higher than that of even-aged monocultures of Scots pine and Norway spruce. Based on these findings, a scaled index was developed that quantifies structural attributes of TLS point clouds and can significantly distinguish continuous cover forests from even-aged forests. This index may be a useful tool to quantify the difference in structure of a given continuous cover forest stand from a "target structure", meaning the theoretical structure describing an ideal continuous cover forest.
\end{abstract}

Keywords: Continuous cover forestry, permanent forest, close-to-nature, forest structure, structural complexity, Carpathian Biosphere Reserve 


\subsection{Introduction}

An essential role of modern forest management is to create multifunctional and resilient forests that resemble natural forests (Brang et al. 2014, Gustaffson et al. 2012, Kuuluvainen 2009, Nagel et al. 2013, O’Hara 2001, O’Hara et al. 2007, Schall et al. 2018a), and which accommodate the increasing societal demands on forest ecosystems (Felipe-Lucia et al. 2018). As a management type, continuous cover forestry (CCF) is considered one option with the potential to fulfill a variety of functions at the same time and location (Mizunaga et al. 2010). Most studies of CCF have addressed possible ways to convert even-aged forest stands into uneven-aged forest stands (v. Lüpke et al. 2004, O'Hara 2001) or to convert existing forest structures into steady-state structures (Pukkala 2016), but little is known about the quantification of the structural characteristics of CCF (Pommerening and Murphy 2004, Pukkala 2016).

The term "continuous cover forest" (in German: "Dauerwald") has a long and turbulent history in German forestry (e.g., Bode 1992, Schmidt 2009, Zingg 2003). It was first mentioned in 1920 by Alfred Möller to describe a management system developed in northeastern Germany (Möller 1920). Möller called for the abandonment of clearcuts in order to secure forests' constancy, by suggesting vertically structured forests. He also advocated ensuring this structure over time by carefully applying single-tree selection cuttings (Schütz 1999b, 2002). Although CCF does not ask for specific management practices to achieve constancy (Möller 1922), there are some guidelines for managers. Möller (1922) stated that the silvicultural methods applied in CCF should depend on and require adaptation to particular climatic and geographic conditions as well as to the target tree species. CCF does not involve classical rotation periods (age-based) and in order to preserve the constancy of the forest system, clearcuts are prohibited (Kraut 2010, Möller 1922, O’Hara 2016, Schabel and Palmer 1999, Stähr and Müller 2010, Zingg 2003). Natural regeneration is preferable, but it may be artificially supplemented with appropriate mixed tree species. Most common is selective thinning, which removes the competitors of the most vital and valuable trees. It is not maximum volume output that is sought, but rather that, which ensures maximum production of high-quality wood (Möller 1922, Stähr and Müller 2010). The concept comprises frequent but moderate group-, patch- or single-tree thinnings (Möller 1922, Zingg 2003), wherein rare mixed tree species should be promoted (Möller 1922, Pommerening and Murphy 2004). Consideration of all these factors should result in an uneven-aged, site-appropriate, 
species-rich and highly productive CCF. However, the CCF concept is being applied successfully within pure European beech stands also (Fritzlar and Biehl 2006), since European beech is a very shade-tolerant species and is able to develop vertically structured stands.

Like all other management concepts, CCF is based on operational decisions by forest owners (Möller 1922, Zingg 2003). However, applying the CCF concept does not mean that all stands will immediately exhibit the desired structure. In contrast, it may last for decades until the desired structure is achieved. Therefore, it would be desirable if a target structure was defined and if a quantitative measure existed that could be used to decide comprehensively and objectively whether a specific stand has already reached that target structure. In the literature, the target state of CCF is qualitatively described as an unevenaged, multi-layered, mixed, and healthy forest ecosystem with high vertical and horizontal heterogeneity (Kraut 2010, Pommerening and Murphy 2004, Stähr and Müller 2010). However, even after a century, there is no clear, objective quantification of this "ideal" structure. Therefore, development and establishment of a structural definition of this "target" state of a CCF stand based on some objective quantification is sorely needed. To capture forest structures reproducibly, we used terrestrial laser scanning (TLS). TLS generates 3D-point clouds, which reproduce a forest in spatial detail and make it possible to calculate several indices describing forest structure.

Perhaps the most important characteristic of the CCF target structure is a state of equilibrium in biomass and constancy of both the forest ecosystem and any compartments and subsystems (Hofmann 2010). Accounting for ways in which space is occupied and according to the plenter (selection) principle, each diameter class should be represented (Schütz 2002, Zingg 2003). Translated into three-dimensional space, this would mean that each stand layer is similarly filled with plant material horizontally and vertically. This state should result in maximum structural complexity (for our definition of complexity see below). Here, we used different indices based on three-dimensional structure to capture the different components of stand structure: the box dimension (Seidel 2018), space filling (Juchheim et al. 2017), and a stand structural complexity index (SSCI, Ehbrecht et al. 2016). In addition, as a measure of equality in space filling between the stand layers, we used space filling evenness, Gini-coefficient, and skewness. Using a combination of these indices and attributes, we hypothesized that it is possible to clearly distinguish conventional even-aged stands of different stages from stands that have been 
managed for decades according to the CCF concept, and which are widely recognized by practitioners to represent the ideal structure of a CCF.

We used eight stands that represented the CCF target structure. These were compared with a series of age-class forests and data from temperate European beech primary forests as unmanaged natural reference forests. Specifically, we tested the following hypotheses:

a) The plant material of CCF target stands is vertically evenly distributed.

b) The structures of CCF target stands differ significantly from even-aged managed reference stands, but not from unmanaged European beech primary forests, as quantified by a newly developed index of three-dimensional stand structure.

\subsection{Materials and Methods}

\subsubsection{Study sites}

We selected eight forest stands in Germany, which are considered representative of the target state of CCF according to practitioners (members of the German section of Pro Silva (in German: “Arbeitsgemeinschaft Naturgemäße Waldwirtschaft” (ANW)). All CCF target stands, except those in Hainich, were mixtures of at least two tree species. In Hainich European beech dominated and formed nearly pure stands. To cover a wide range of forest types, the study areas and plots represent different tree species compositions, ranging from forest stands dominated by broadleaved or coniferous tree species to mixed stands with similar proportions of broadleaved and coniferous tree species. The forests are located in Kasseedorf/Lensahn (Schleswig-Holstein), Rentweinsdorf, Teisendorf and Ebrach (Bavaria), Freudenstadt (Baden-Wuerttemberg), Gießen (Hesse), Wallmerod (Rhineland-Palatinate) and Hainich (Thuringia; Fig. 4.1 and Table 4.1). While the forest plots in Freudenstadt are dominated by coniferous tree species, in Rentweinsdorf and Kasseedorf/Lensahn both are found; mixed stands dominated by broadleaved tree species and mixed stands dominated by coniferous tree species. In Teisendorf, all forest plots consist of mixtures of broadleaved and coniferous tree species. In Gießen, Wallmerod, Ebrach and Hainich stands are predominately composed of broadleaved tree species (Table 4.1). 
To distinguish between the target state of CCF and stands of other management systems and tree species, we chose reference forest plots in even-aged pure stands (EA) of Norway spruce (Picea abies L.; Swabian Alb, Baden-Württemberg), Scots pine (Pinus sylvestris L.; Schorfheide-Chorin, Brandenburg), European beech (Fagus sylvatica L.; Hann. Münden and Reinhausen, Lower Saxony), and plots in mixed stands of beech, pine and oak (Quercus sp.; Schorfheide-Chorin, Brandenburg). To reduce effects of age we selected stands at the stage of mature timber. Additionally, we used data from temperate European beech primary forests (PF) as an unmanaged reference (Tab. 4.1). The primary forests are located in eastern Slovakia (Rožok) and in western Ukraine (Uholka; for detailed information see Stiers et al. 2018 or Willim et al. 2019).

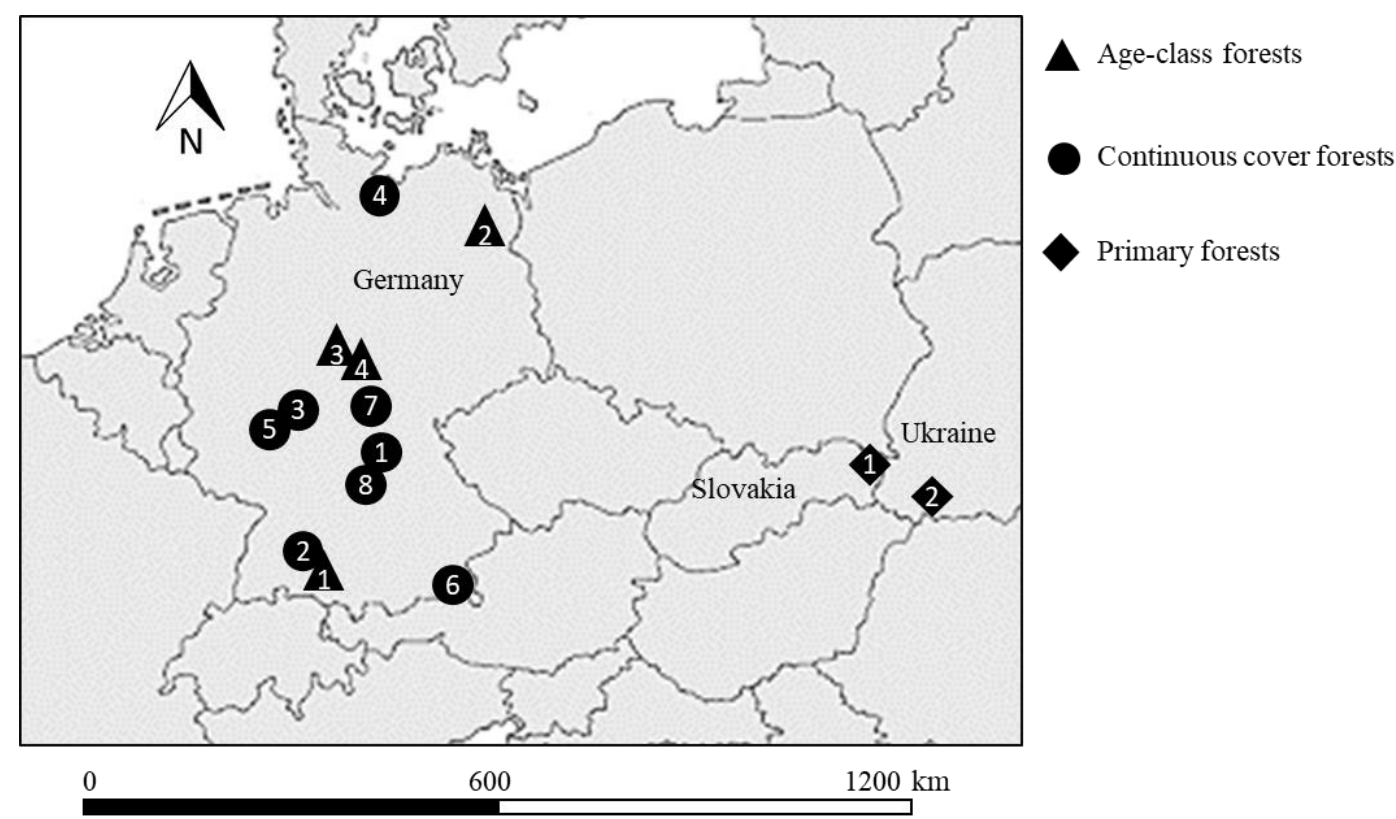

Figure 4.1: Geographic locations of the study areas located in Germany, Slovakia, and Ukraine. Circles represent the eight study areas, which were classified as continuous cover target state forests (CCF), triangles represent the four even-aged forests, and diamonds represent the unmanaged forests. 
Table 4.1: Detailed information on important climatic and geographical properties of the study plots: $\mathrm{CCF}=$ continuous cover forests, $\mathrm{EA}=$ even-aged forests, $\mathrm{PF}=$ primary forests, $\mathrm{n}=$ number of investigated plots, $\mathrm{MAT}=$ mean annual temperature, $\mathrm{MAP}=$ mean annual precipitation.

\begin{tabular}{|c|c|c|c|c|c|c|}
\hline Country & Study area & $\begin{array}{c}\text { MAT } \\
\left({ }^{\circ} \mathbf{C}\right)\end{array}$ & $\begin{array}{l}\text { MAP } \\
(\mathbf{m m})\end{array}$ & $\begin{array}{c}\text { Elevation } \\
\text { (m a.s.l.) }\end{array}$ & $\begin{array}{l}\text { dominating } \\
\text { class of tree } \\
\text { species }\end{array}$ & study plots \\
\hline \multirow{12}{*}{ Germany } & Rentweinsdorf (1) & $8.5-10$ & 750 & $250-300$ & $\begin{array}{l}\text { equal coniferous/ } \\
\text { broadleaved }\end{array}$ & CCF: $n=3$ \\
\hline & Freudenstadt (2) & 9 & 1300 & $750-800$ & coniferous & CCF: $n=2$ \\
\hline & Gießen (3) & $9.5-10$ & 590 & $200-250$ & broadleaved & CCF: $n=3$ \\
\hline & Lensahn (4) & 9 & $500-700$ & $15-50$ & $\begin{array}{l}\text { equal coniferous/ } \\
\text { broadleaved }\end{array}$ & CCF: $n=3$ \\
\hline & Wallmerod (5) & $9-9.5$ & $650-800$ & $85-100$ & broadleaved & CCF: $n=3$ \\
\hline & Teisendorf (6) & $7.5-8$ & 1100 & $550-700$ & $\begin{array}{c}\text { equal } \\
\text { coniferous/broad } \\
\text { leaved }\end{array}$ & CCF: $n=3$ \\
\hline & Hainich (7) & $7-8$ & $600-800$ & $330-380$ & broadleaved & CCF: $n=5$ \\
\hline & Ebrach (8) & $7-8$ & 850 & $320-480$ & broadleaved & CCF: $n=4$ \\
\hline & Swabian Alb (1) & $6-7$ & $\begin{array}{l}700- \\
1000\end{array}$ & $460-860$ & coniferous & EA: $n=5$ \\
\hline & $\begin{array}{l}\text { Schorfheide- } \\
\text { Chorin (2) }\end{array}$ & $8-8.5$ & $500-600$ & $3-140$ & $\begin{array}{l}\text { coniferous }(n=5) / \\
\text { mixed }(n=6)\end{array}$ & EA: $n=11$ \\
\hline & $\begin{array}{l}\text { Hann. Münden } \\
\text { (3) }\end{array}$ & $6-7.5$ & $\begin{array}{l}750- \\
1050\end{array}$ & $270-410$ & broadleaved & EA: $n=4$ \\
\hline & Reinhausen (4) & 8 & 740 & $190-310$ & broadleaved & EA: $n=4$ \\
\hline Slovakia & Rožok (1) & $6-7$ & 780 & $580-745$ & broadleaved & $P F: n=3$ \\
\hline Ukraine & Uholka (2) & 7 & 1407 & $700-840$ & broadleaved & PF: $n=2$ \\
\hline
\end{tabular}

\subsubsection{Terrestrial Laser Scanning and sampling design}

At each study site, we collected data from a minimum of two forest plots (Table 4.1). The plots were located away from skidding trails and at a minimum distance of $10 \mathrm{~m}$ from roads. The two plots of a given study site were at least $50 \mathrm{~m}$ apart from each other. At the selected plots, an area of at least $40 \times 40 \mathrm{~m}$ was scanned with a Faro Focus M70 (Faro Technologies Inc., Lake Mary, FL, USA) terrestrial laser scanner. The laser scanner was mounted on a tripod at breast height $(1.3 \mathrm{~m})$ and covered a field of view of $300^{\circ}$ in vertical and $360^{\circ}$ in horizontal directions with an angular step width of $0.035^{\circ}$, which resulted in 44.4 million measurements per scan. However, to enable efficient processing of the large point clouds we reduced the data to every $4^{\text {th }}$ point in every $4^{\text {th }}$ row $(1 / 16$ of initial resolution) as conducted in earlier studies (e.g. Seidel et al. 2013, Juchheim et al. 2017). Using phase-difference technology, the scanner emits laser beams into the forest and detects those beams reflected from surrounding objects at a maximum distance of $70 \mathrm{~m}$. 
To reproduce these data as a highly detailed 3D-point cloud, we performed between 30 and 80 systematically arranged scans on each plot. The number of scans required depends on the density of the understory and the aim is to minimize occlusion effects within the plots (Ehbrecht et al. 2016). In their study, around 9 scans were needed to eliminate occlusion effects. With regard to our extremely high number of scans per plot occlusion effects should be negligible. Understory density is influenced by the number and diameter of stems and branches, which, in the case of young stands with small trees, can be very dense, with small gaps in the vegetation (Ehbrecht et al. 2016). For the co-registration of the individual single-scans, we evenly distributed 70 to 90 artificial checkerboard targets (laminated DIN A4 paper) in the plot area. Data from reference plots (primary and evenaged) and from Ebrach and Hainich were obtained from previous scanning campaigns in the course of other research projects. All data were collected during the vegetation period, when all trees were densely foliated. In total, we collected data from 55 forest plots located in 14 study areas (Tab. 4.1).

\subsubsection{Point cloud processing and data analysis}

To filter for erroneous points and spatial co-registration, we used the standard settings of the Software Faro Scene (Faro Technologies Inc., Lake Mary, FL, USA, and Version 7.1.1.81). For further processing, each 3D-point cloud was exported as an xyz-file. Each point cloud was then converted into a voxel model (voxel $=$ volumetric pixel) with an edge length of $20 \mathrm{~cm}$. The voxel size influences the calculations of the metrics. If voxels are chosen too small, it is likely that tree stems are represented as hollow "pipes" instead of solid bodies (Seidel et al. 2013). Also, occlusion effects may result in artificial gaps in the voxel model. Larger voxel sizes can be considered more conservative and are an effective tool to minimize occlusion effects (Ehbrecht et al. 2016) but may result in an overestimation of the actual space filling. If chosen too large, smaller gaps are missed and space filling increases. Here, we decided to use $20 \mathrm{~cm}$ voxels as they were shown to be a robust way to deal with occlusion for plots identical to ours in size (Ehbrecht et al. 2016) while still providing a high-resolution model of the forest preserving detailed structures (Fig. 4.2). This is because at the chosen scanning resolution the distance between two laser beams at maximum measuring distance of the scanner $(70 \mathrm{~m})$ is $4.3 \mathrm{~cm}$. After point cloud reduction to $1 / 16$ of the original (see above) for computability of the data, beamto-beam distance increases to $17.3 \mathrm{~cm}$ at $70 \mathrm{~m}$ distance to the scanner. To ensure that 
there is no unsampled space between neighboring points $20 \mathrm{~cm}$ voxels are suitable and may be considered the smallest possible voxel model.

To account for uneven terrain, we normalized the topography by computing digital terrain models (DTM) through triangulation of the lowermost voxel in each grid cell. We then normalized the point cloud by correcting each voxel in the voxel model with the underlying terrain height obtained from the DTM. Details of the approach can be found in Juchheim et al. (2017).

Based on these normalized voxel models of $20 \mathrm{~cm}$ edge length, we used an algorithm written in R ( $\mathrm{R}$ Core Team 2017) to calculate relative space filling for a predefined horizontal extent of $40 \times 40 \mathrm{~m}$. Space filling is the percentage of the total plot volume that is occupied by plant voxels (Juchheim et al. 2017, Seidel et al. 2019a). Total plot volume was defined as ground area, which is $40 \times 40 \mathrm{~m}=1600 \mathrm{~m}^{2}$, multiplied by median stand height. To define the median height, which was used for further calculations, we separated the upper $20 \%$ of stand height, and calculated the median for these selected zvalues (Fig. 4.2). This was done to eliminate shadowing within the dense leaf-on data, which could have resulted an underestimation of the upper canopy parts. Before the calculation of relative space filling, we deleted all voxels of the five lowermost voxel layers (0-1 m) (Fig. 4.2). If these points, representing ground, grasses, herbs, ferns, and leaf litter, had not been deleted, space filling would have been overestimated for the lower stand layers. Space filling was calculated for the space above the lowermost voxel layers and median stand height. The space that is occupied by voxels is determined by simply counting all voxels and multiplying them by their volume $\left(0.008 \mathrm{~m}^{3}\right)$.

Here, space filling was also used to calculate the percentage of filled volume in predefined forest layers and thus to describe the spatial arrangement of plant material. Therefore, each plot was vertically subdivided into 50 equally thick layers relative to the median stand height. Sensitivity analyses showed that the results presented below were robust even with lesser layers (data not shown). In a next step, we calculated space filling in percentage of each layer from the total. 


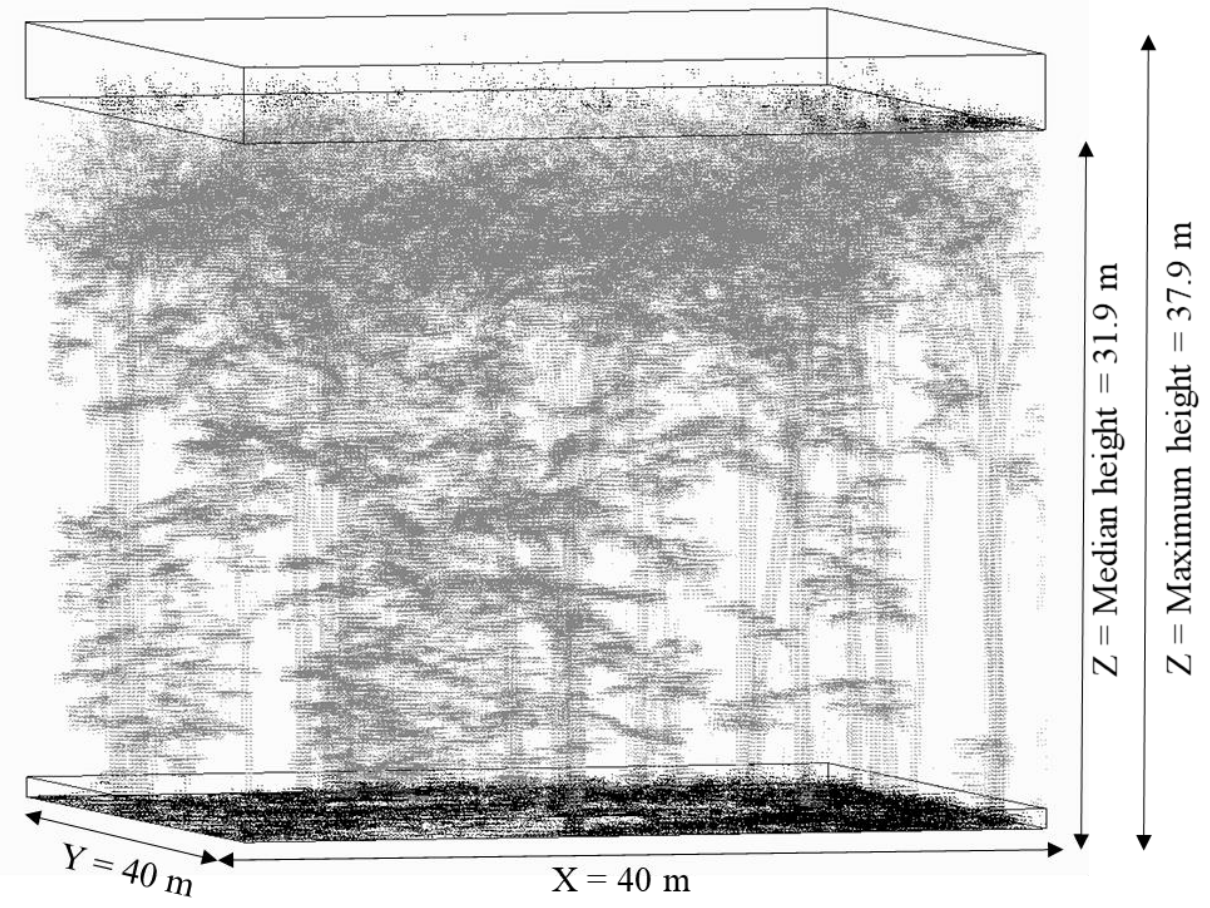

Figure 4.2: Illustration of the voxel model and subdivisions. Black voxels mark the five lowermost bottom layers $(<1.0 \mathrm{~m})$ in the voxel model, which were deleted before data analysis (bottom black voxels), and the voxels which were deleted through the reduction of maximum stand height to median stand height (top black voxels).

To analyze the spatial distribution of and disparity in space filling, we used accumulation curves, to display the cumulative arrangement of space filling in the vertical layers of the scanned forests. In addition, we calculated the Gini-coefficient, the evenness, the skewness, and the coefficient of variation to describe the inequality in space filling between the defined stand layers (Bendel et al. 1989). The evenness ( $\left.E_{1 / D}\right)$ using 'Simpson's measure of evenness' (1) and the Gini-coefficient were applied to quantify the homogeneity of space filling in the vertical and horizontal layers. They vary between zero and one, with values close to one indicating a high homogeneity among the layers. The Gini-coefficient was computed with the R package "ineq" (Zeileis et al. 2009). Evenness was calculated as follows:

(1) $E_{1 / D}=\frac{1 / D}{s} ; D=\sum p_{i}{ }^{2} ; p_{i}=$ space filling in layer $i ; s=$ number of layers $(50)$

Since the Gini-coefficient, evenness, and coefficient of variation indicate the degree of homogeneity, but not the direction of possible deviations, we additionally calculated the skewness (skew) based on space filling in the vertical layers in order to determine where a potential disproportionality was located. Negative values indicate left-skewed distributions, which represent disproportionally filled canopy layers, while positive 
values describe right-skewed distributions, which indicate disproportionally filled lower stand layers. The closer the value to zero, the more homogeneous the distribution.

Furthermore, we calculated the box dimension $\left(D_{b}\right)$, which addresses structural complexity based on fractal analysis. It links relative space filling to the spatial distribution of biomass and is thus a meaningful measure of three-dimensional complexity (Seidel 2018, Seidel et al. 2019a, 2019b). Db increases with increasing density and structural complexity of a forest stand. In addition, it accounts for the homogeneity of the spatial distribution of complexity, thus increases with increasing homogeneity, and can therefore be a helpful tool to quantify the structure of forest stands. $\mathrm{D}_{\mathrm{b}}$ is defined as the slope of a linear model (least square fit) on the scale of $\log (\mathrm{N})$ over $\log (1 / \mathrm{r})$, with $\log ()$ being the natural logarithm, and $\mathrm{N}$ being the number of boxes of size $\mathrm{r}$ needed to enclose all points in a three-dimensional point cloud (Mandelbrot 1977, Seidel 2018). The $\mathrm{D}_{\mathrm{b}}$ of a forest is defined to be greater than 1 (pole) and lower than the maximal value of 2.72 , which is the dimensionality of the Menger sponge, a theoretical concept of infinite dimensionality and zero volume (introduced by Menger (1926); Seidel et al. 2019a).

In addition to the voxel models derived from the multi-scans, we selected eight individual single-scans from each study plot located in six of the CCF target stands (Lensahn, Rentweinsdorf, Freudenstadt, Gießen, Wallmerod, and Teisendorf). These 144 singlescans were filtered with the standard settings of the Faro Software Faro Scene (Faro Technologies Inc., Lake Mary, FL, USA, Version 7.1.1.81) and then exported as separate xyz-files. Next, the "stand structural complexity-index" (SSCI, Ehbrecht et al. 2017) was calculated to generate further single-scan based structural measures for the description of structural complexity in CCF target stands. The SSCI was calculated using an algorithm written in Mathematica (Wolfram Research Champaign, IL, USA) and is based on the three-dimensional distribution of objects within a scanned forest scene. The SSCI considers the whole forest stand above diameter at breast height $(1.3 \mathrm{~m})$, and describes the relationship between the areas and perimeters of multiple vertical cross-sectional polygons through the forest scene, which are received from the scanner's perspective. The relationship between circumference and area of these cross-sectional polygons is used to mathematically describe the complexity of the stand. For more details on index construction and possible value-range, see Ehbrecht et al. (2017). 


\subsubsection{Quantifying CCF target structure}

Based on consideration of the structural characteristics of CCF target structures, we designed another index composed of the variables $\mathrm{D}_{\mathrm{b}}$, skew, and height. The index ("index of structural constancy", ISC) is expected to yield a sensible quantification of the structure found in stands belonging to different forestry systems. Index values should approach a maximum value for stands most similar to the target structures of the CCF system. The ISC was computed for every study plot using the following formula:

$$
I S C=D_{b w} * \text { Skew }_{w} * \text { Height }_{w}
$$

$\mathrm{D}_{\mathrm{b}}$ was normalized ( $\left.\mathrm{D}_{\mathrm{bw}}\right)$ to range from 0 to 1 by using the mathematical minimum 1 and the assumed maximum of 2.72 for $\mathrm{D}_{\mathrm{b}}$. For CCF target stands, we hypothesized space filling to be homogeneous, which means that every stand layer was equally filled with plant material. The skewness-value for such forests would lie around zero. For index construction, the skewness was also normalized to range from 0 to 1 . The necessary weighting was based on assumptions related to the Standard normal distribution (formula 3; Fig. 4.3a).

$$
\text { (3) } \frac{1}{\sqrt{2 \pi \sigma^{2}}} e^{\left(-\frac{(x-\mu)^{2}}{2 \sigma^{2}}\right)}
$$

Thus, forests plots with skewness values near zero would have the highest values for weighted skew. Weighting the skewness in a standard normal distribution penalizes stands in which the upper canopy layers contribute disproportionately to the total plot filling, i.e., stands with negative values for skewness. Thus, mono-layered stands with higher space filling in the canopy layers than in the lower layers would receive low values for weighted skew. It would also likewise penalize stands in which space filling of lower stand layers was dominated by, i.e., stands with positive values for skewness. However, to account for the presence of abundant regeneration, which is essential for the CCF concept, we wanted to allow for a tolerance interval in which a higher space filling in lower stand layers was tolerated and did not lead to a reduction in the value of weighted skew. We defined this tolerance interval for skewness values between 0 and 1 and added a stretched minimum function to the standard normal distribution, which ensured that all plots with skewness values within this tolerance interval were assigned the value 1 for weighted skewness (Fig. 4.3a). The tolerance interval ranges to skewness values of 1 , above which the skewness is considered to significantly deviate (Bulmer 1979). In our case, this meant that disproportionality in space filling in the lower stand layers would represent a significant deviation from the hypothesized equal distribution. The standard 
normal distribution is usually parameterized by setting $\mu=0$ and $\sigma=1$. For technical reasons, we had to change the local parameter $\mu$. This was necessary both to establish the tolerance interval to range from 0 to 1 and because we could not completely exclude the possibility of underestimating the filling of upper layers due to occlusion effects, despite the large number of scans and a voxel side length of $20 \mathrm{~cm}$ (Ehbrecht et al. 2016). Occlusion effects would result in a bias towards a more right-skewed distribution of plant material. To compensate for this possible right-skewness resulting from methodological constraints, we slightly shifted the local parameter $\mu$ of the normal distribution to 0.5 .

Stand height was included as a third index component. However, stand height was only included to control for a minimum forest height. The threshold (see below) was set to distinguish forest stands from other systems, such as cornfields, which might also show high $\mathrm{D}_{\mathrm{b}}$ values and a skewness around 0. To set a reliable threshold of stand height, we used a Chapman-Richards-function (eq. 4), with the parameters $\mathrm{k}=0.035$ and $\mathrm{p}=10$ (Fig. 4.3d).

$$
\text { (4) } \quad y(x)=1\left(1-e^{-k x}\right)^{p}
$$

Using these parameters, the weighted value for stand height $\left(\right.$ Height $\left._{\mathrm{w}}\right)$ lies around 1 for stands with a mean stand height greater than $20 \mathrm{~m}$. For stand height decreasing from about 20 to $13 \mathrm{~m}$, the values decrease slowly. Values for heights falling below $13 \mathrm{~m}$ decrease increasingly rapidly. These threshold-values were based on the assumption that regardless of species, age, and site factors, a CCF stand with heights greater than $13 \mathrm{~m}$ should have reached a forest structure with one or more distinct stand layers. 


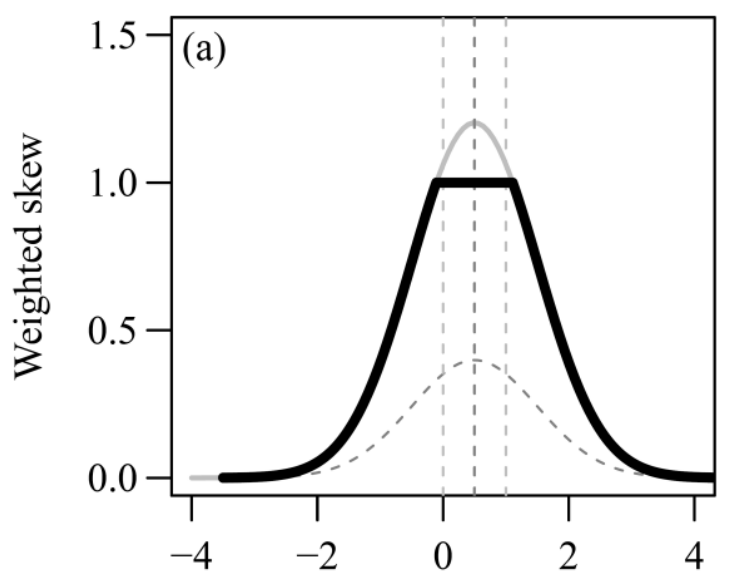

Skew

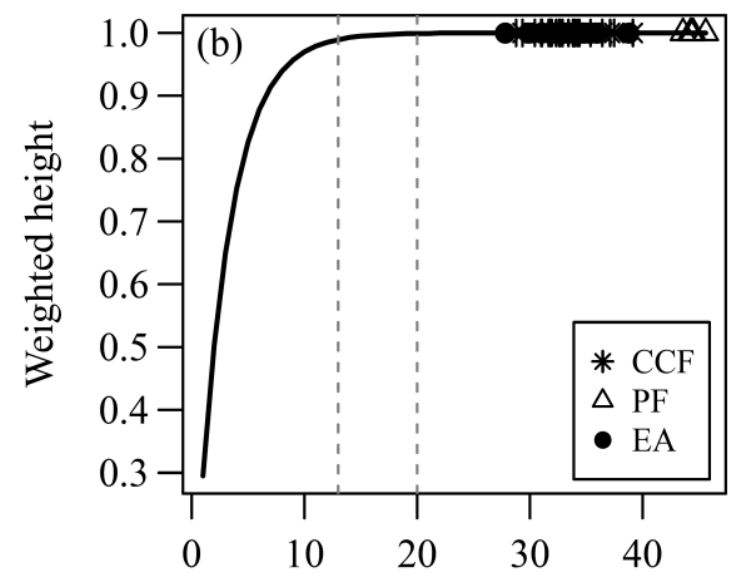

Height

Figure 4.3: (a) shows the weighted skewness in a standard normal distribution with stretched minimum function. The dashed horizontal lines mark the regular normal distribution (dark grey), while the dashed vertical lines mark skewness values of 0 and 1 (light grey) as well as the mean skewness (dark grey). The black solid line shows the weighted skewness with stretched values between 0 and 1. (b) shows the weighted height using a Chapman-Richards-function (4), while the dashed vertical lines represent the threshold values of 13 and $20 \mathrm{~m}$.

\subsubsection{Statistical analysis}

To test for differences between the stands of the different management types, we used parametric and non-parametric tests to analyze the data, depending on whether parametric assumptions (normal distribution and homogeneity of variance) were met. We used the Shapiro-Wilk-test as normality-test, because it is also applicable for small sample sizes. We tested for homogeneity of variance by using Levene's test. If the data met the requirements for parametric tests, we used One-way-ANOVA to test for differences between the variables followed by a TukeyHSD-test for posthoc comparisons. This way, we tested for differences in box dimension and skewness between the management types. In cases where the parametric assumptions were not met, we used the non-parametric Kruskal-Wallis-ANOVA and the Mann-Whitney U-test. This was done to test for differences in space filling, vertical and horizontal evenness between management types, differences in ISC between management types, differences between the broadleaved, coniferous, and mixed forest types, as well as the mean deviation of the accumulation curves. For all statistical tests, we used a significance level of $\mathrm{p}<0.05$. The statistical analyses were conducted in the R environment (R Core Team 2017). 


\subsection{Results}

\subsubsection{Structural differences between the types of management}

The accumulation curves of space filling showed varying proportions in the defined stand layers for CCF target stands, even-aged forests, and primary forests (Fig. 4.4). We found significant differences $(\mathrm{p}<0.001)$ in mean divergence from the homogeneous vertical distribution of plant material between the CCF target stands and the even-aged forests $(\mathrm{p}<0.001)$, as well as between the even-aged forests and the primary forests $(\mathrm{p}=0.048)$, but not between the CCF target stands and the primary forests $(\mathrm{p}=0.755$; Tab. 4.2). Mean divergence was lowest in the primary forests, highest in the even-aged forests, and intermediate in the CCF target stands (Tab. 4.2). The skewness indicated that only the primary forests did not deviate significantly from the hypothesized homogeneous vertical distribution of plant material $(\mathrm{p}=0.718)$, but both the even-aged forests $(\mathrm{p}<0.001)$ and the CCF $(\mathrm{p}=0.002)$ did.

Considering space filling not cumulatively, but separately in each of the defined stand layers, the spatial heterogeneity of vertical levels became clear through the coefficient of variation and the Gini-coefficient. Thus, the $\mathrm{CV}$ of space filling across layers indicated the most homogeneous distribution in the primary forests $(\mathrm{CV}=0.456)$, slightly less homogeneous distribution in the $\mathrm{CCF}$ target stands $(\mathrm{CV}=0.473)$, and the most heterogeneous distribution in the even-aged forest stands $(\mathrm{CV}=0.727)$. The mean Ginicoefficients were significantly different between CCF and even-aged forests $(p<0.001)$, and between primary forests and even-aged forests $(\mathrm{p}=0.037)$, but not between CCF and primary forests $(\mathrm{p}=0.966)$. 


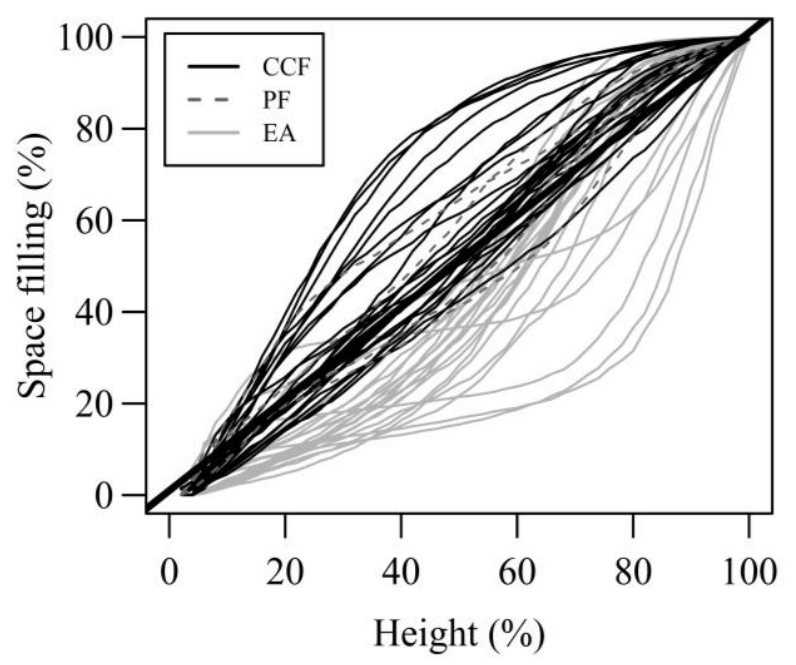

Figure 4.4: Accumulation curves showing the cumulative relative space filling over relative stand height. The angle bisector marks the exemplary course for a homogeneously distributed space filling, which means each stand layer is equally filled.

Table 4.2: Descriptive statistics for the divergence from the homogeneous distribution of the continuous cover target forests (CCF), the even aged forest stands (EA), and the primary forests (PF). Mean sum positive and mean sum negative summarize all deviations in space filling in each layer from the hypothetical equal distribution. $\mathrm{SD}=$ Standard deviation, $\mathrm{CV}=$ Coefficient of Variation.

\begin{tabular}{ccccccc}
\hline $\begin{array}{c}\text { Type of } \\
\text { Management }\end{array}$ & $\begin{array}{c}\text { Gini- } \\
\text { coefficient } \\
\text { (mean) }\end{array}$ & $\begin{array}{c}\text { Mean Sum } \\
\text { positive }\end{array}$ & $\begin{array}{c}\text { Mean Sum } \\
\text { negative }\end{array}$ & Mean & SD & CV (\%) \\
\hline CCF & 0.27 & 328.58 & -41.70 & 5.91 & 4.97 & 3.08 \\
EA & 0.38 & 79.59 & -458.14 & -7.87 & 9.48 & 1.77 \\
PF & 0.25 & 226.40 & -61.36 & 3.37 & 4.39 & 23.94 \\
\hline
\end{tabular}

Considering $\mathrm{D}_{\mathrm{b}}$, we found that all management types significantly differed from one another (PF-EA: $p<0.001$; PF-CCF: $p=0.022$; CCF-EA: $p<0.001$, Fig. 4.5a and Tab. 4.3). We also found that $\mathrm{D}_{\mathrm{b}}$ was significantly higher in the CCF target stands than in the even-aged stands and was highest in the primary forests $(\mathrm{p}<0.001$, Fig. 4.5a). In the CCF target stands only, we observed no significant differences in $\mathrm{D}_{\mathrm{b}}$ between stands dominated by broadleaved tree species $\left(\mathrm{D}_{\mathrm{b}}=2.334\right)$, equally mixed conifers and broadleaved tree species $\left(\mathrm{D}_{\mathrm{b}}=2.378\right)$, and coniferous-dominated CCF target stands $\left(D_{b}=2.374\right)$. However, we found significant differences in $D_{b}$ between even-aged stands dominated by Scots pine and Norway spruce $(\mathrm{p}=0.032)$, as well as between Scots pine and European beech (Fig. 4.5a, and Tab 4.4; p < 0.001). 
Space filling was highest in the CCF target stands. We found significant differences to the primary forests ( $p=0.014$; Fig. $4.5 b$ and Tab. 4.3), but on average not to the evenaged forests $(\mathrm{p}=0.056$, Fig. $4.5 \mathrm{~b}$ and Tab. 4.3). Vertical evenness was significantly higher in the CCF target stands than in the even-aged forests $(p=0.013)$. However, no significant differences were found with the primary forests $(p=0.851)$, which had the highest vertical evenness. There were no significant differences in horizontal evenness between the primary forests, the CCF target stands, and the even-aged stands ( $p=0.856$; Tab. 4.3).

Vertical evenness was found to be highest in the CCF. They differed significantly from the even-aged stands $(\mathrm{p}=0.013)$, but not from the primary forests $(\mathrm{p}=0.851)$. The same results were found for skewness. It was highest in CCF target stands, indicating a rightskewed distribution with disproportionally filled lower stand layers. Even-aged forests were the opposite $(\mathrm{p}<0.001)$ : disproportional filling of the canopy layer was expressed by left-skewed distributions (Fig. 4.5c and Tab. 4.3).
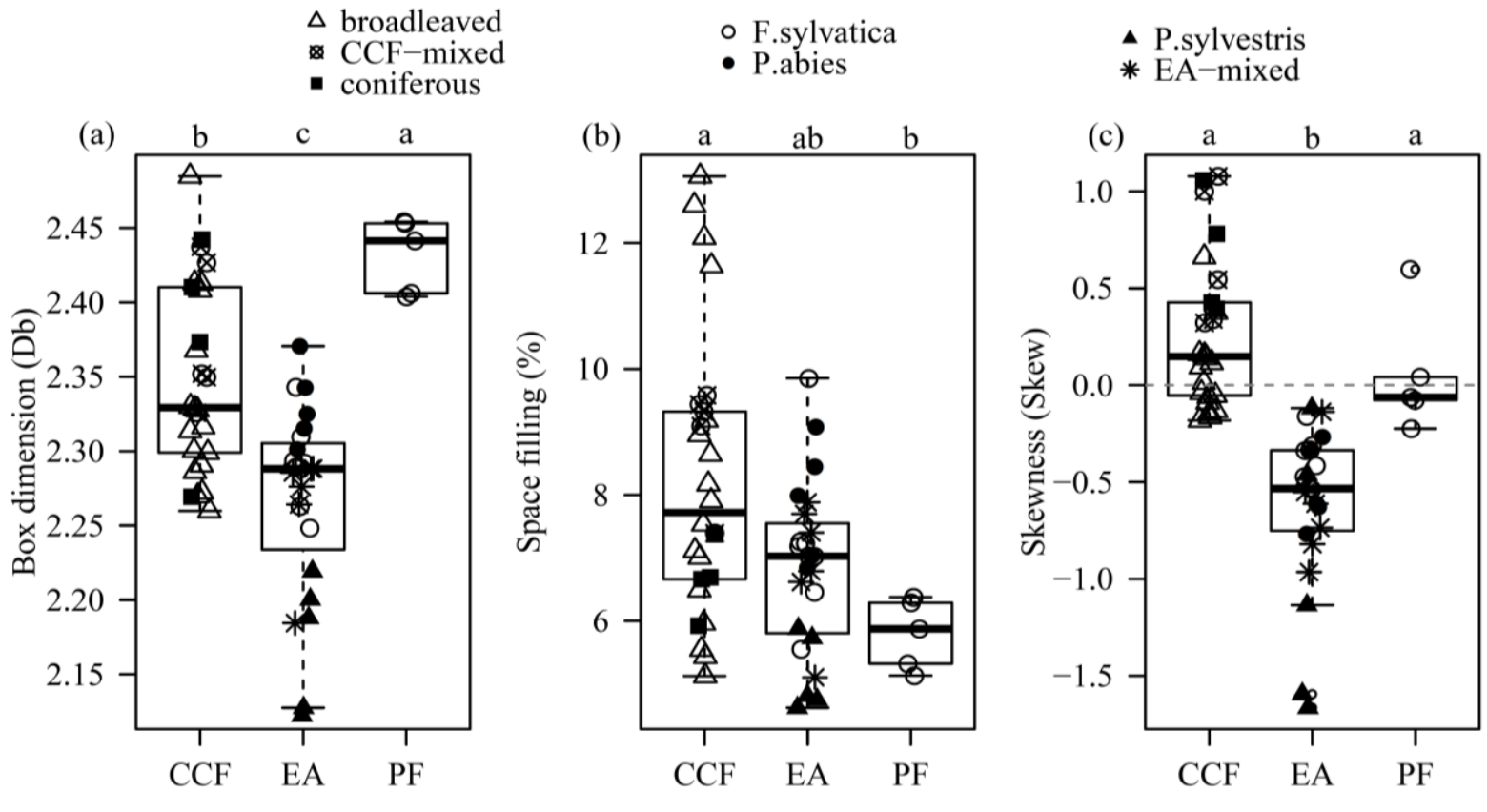

Management type

Figure 4.5: Box-Whisker plots of box dimension $\left(D_{b}\right)$, relative space filling and skewness of different management types: continuous cover forests (CCF), even-aged forests (EA), and primary forests (PF). Black horizontal lines indicate the median. Lowercase letters indicate significant differences between the management types $(\mathrm{p}<0.05)$. Sample sizes in CCF: $n=26, E A: n=24, P F: n=5$. 
Table 4.3: Descriptive statistics for box dimension $\left(D_{b}\right)$, relative space filling $(S F)$, vertical $\left(E_{v e r}\right)$ and horizontal $\left(\mathrm{E}_{\mathrm{hor}}\right)$ evenness and skewness (Skew) of continuous cover forest target stands $(\mathrm{CCF})$, even-aged forest stands $(\mathrm{EA})$, and primary forests $(\mathrm{PF}) . \mathrm{Min}=$ minimum, Max $=$ maximum, Var $=$ variance, $\mathrm{SD}=$ standard deviation, $\mathrm{CV}=$ coefficient of variation. The lowercase letters indicate significant differences in the indices between management types $(\mathrm{p}<0.05)$.

\begin{tabular}{|c|c|c|c|c|c|c|c|c|}
\hline $\begin{array}{c}\text { Type of } \\
\text { Management }\end{array}$ & Index & Mean & Median & Min & $\operatorname{Max}$ & Var & SD & $\begin{array}{l}\text { CV } \\
(\%)\end{array}$ \\
\hline \multirow{5}{*}{$\mathrm{CCF}$} & $\mathbf{D}_{\mathrm{b}}$ & $2.35^{b}$ & 2.33 & 2.26 & 2.48 & 0.063 & 0.004 & 2.69 \\
\hline & SF & $8.23^{\mathrm{a}}$ & 7.72 & 5.12 & 13.06 & 2.223 & 4.942 & 27.02 \\
\hline & $\mathbf{E}_{\mathrm{ver}}$ & $0.79^{\mathrm{a}}$ & 0.82 & 0.54 & 0.94 & 0.118 & 0.014 & 14.98 \\
\hline & $\mathbf{E}_{\text {hor }}$ & $0.96^{\mathrm{a}}$ & 0.96 & 0.92 & 0.98 & 0.020 & 0.000 & 2.05 \\
\hline & Skew & $0.27^{\mathrm{a}}$ & 0.15 & -0.18 & 1.08 & 0.384 & 0.148 & 143.86 \\
\hline \multirow{5}{*}{ EA } & $\mathbf{D}_{\mathrm{b}}$ & $2.27^{c}$ & 2.29 & 2.12 & 2.37 & 0.064 & 0.004 & 2.84 \\
\hline & SF & $6.84^{\mathrm{ab}}$ & 7.03 & 4.62 & 9.85 & 1.338 & 1.791 & 19.55 \\
\hline & $\mathbf{E}_{\mathrm{ver}}$ & $0.67^{\mathrm{b}}$ & 0.72 & 0.35 & 0.91 & 0.148 & 0.022 & 21.98 \\
\hline & $\mathbf{E}_{\text {hor }}$ & $0.96^{\mathrm{a}}$ & 0.97 & 0.90 & 0.99 & 0.024 & 0.001 & 2.53 \\
\hline & Skew & $-0.60^{b}$ & -0.53 & -1.67 & -0.12 & 0.404 & 0.163 & -66.90 \\
\hline \multirow{5}{*}{ PF } & $\mathbf{D}_{\mathrm{b}}$ & $2.43^{\mathrm{a}}$ & 2.44 & 2.40 & 2.45 & 0.025 & 0.001 & 1.02 \\
\hline & SF & $5.80^{\mathrm{b}}$ & 5.87 & 5.13 & 6.37 & 0.560 & 0.313 & 9.65 \\
\hline & $\mathbf{E}_{\text {ver }}$ & $0.83^{\mathrm{a}}$ & 0.83 & 0.78 & 0.90 & 0.043 & 0.002 & 5.23 \\
\hline & $\mathbf{E}_{\text {hor }}$ & $0.97^{\mathrm{a}}$ & 0.96 & 0.95 & 0.98 & 0.010 & 0.000 & 0.99 \\
\hline & Skew & $0.06^{\mathrm{a}}$ & -0.06 & -0.22 & 0.60 & 0.318 & 0.101 & 576.88 \\
\hline
\end{tabular}

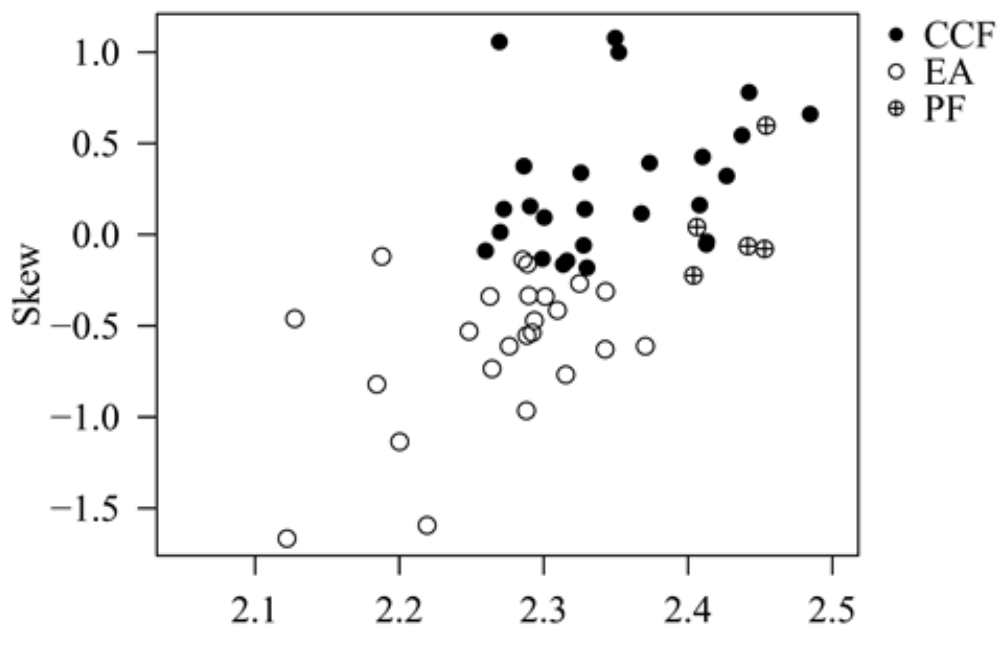

Box dimension

Figure 4.6: Scatterplot of the Skewness over Box dimension. The different symbols mark the different management types investigated here. Sample sizes: CCF: $n=26, E A: n=24, P F: n=5$. 
Linking the two main components of the newly developed index, skewness and box dimension before weighting, resulted in a clear separation of CCF and even-aged stands (Fig. 4.6). The highest values for $\mathrm{D}_{\mathrm{b}}$ were found in stands with skewness values near zero or a small deviation to right-skewed distributions, which was the case for the primary forests and most of the CCF.

\subsubsection{ISC and SSCI in different types of forest management}

ISC differed by different management and forest types (Fig. 4.7a). The mean index-value was highest in the primary forests $(P F=0.799)$. Significant differences were found between primary forestsand even-aged forests $(\mathrm{EA}=0.471, \mathrm{p}<0.001)$, but not between primary forests and CCF targest stands $(\mathrm{CCF}=0.768, \mathrm{p}=0.19)$. ISC of the CCF target stands was also significantly higher than that of the even-aged stands $(\mathrm{p}<0.001)$. There was no overlap of the ISC values between the even-aged forest stands (ISC $\max =0.691$ ) and the continuous cover target stands (ISC $\min =0.0694$ ). No significant differences were found between stands of the different tree species when considering the even-aged stands (Tab. 4.4). However, the even-aged stands dominated by beech and the mixed even-aged forests were not significanly different from the mixed and coniferous $\mathrm{CCF}$ (Tab. 4.4).

We found significant differences in stand structural complexity (SSCI) between CCF target stands $(\mathrm{SSCI}=6.564)$ and even-aged forests $(\mathrm{SSCI}=5.664 ; \mathrm{p}<0.001)$ and between primary forests $(\mathrm{SSCI}=6.632)$ and even-aged stands $(\mathrm{p}=0.004)$. There were no significant differences in SSCI between CCF target stands and the primary beech forests considered here (Fig. 4.7b).

Within the group of CCF target stands we found no significant differences in ISC. Thus comparable results were obtained for $\mathrm{CCF}$ target stands dominated by broadleaved tree species, those with equal mixes of broadleaved and conifer species, and stands dominated by conifers. 
$\triangle$ broadleaved $\circ$ F.sylvatica

¿CF-mixed $\bullet$ P.abies

- coniferous $\Delta$ P.sylvestris

* EA-mixed

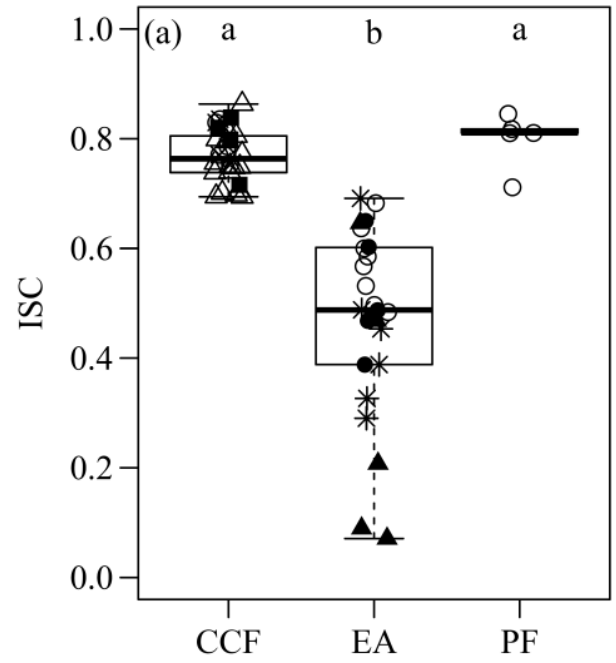

Management type

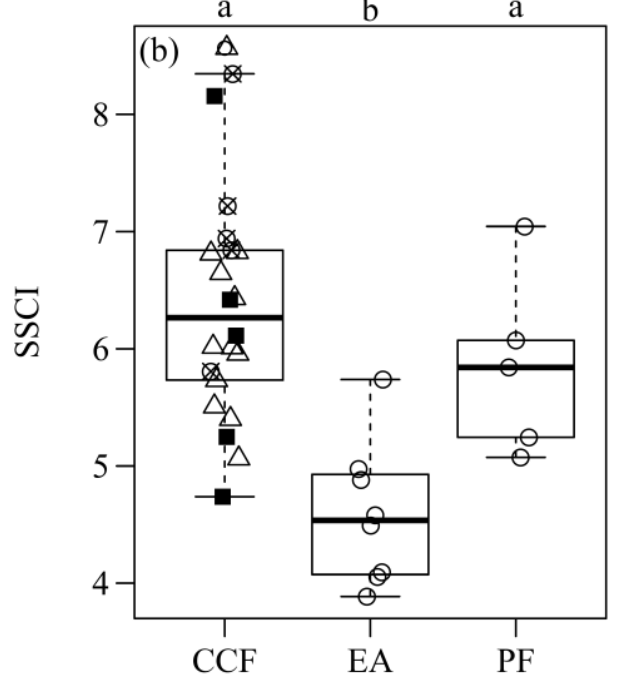

Management type

Figure 4.7: (a) Box-Whisker plots of the index of structural constancy (ISC) (b) and stand structural complexity-index (SSCI) depending on management type and species composition: continuous cover forests $(\mathrm{CCF})$, even-aged managed forests (EA), and primary forests (PF). Black horizontal lines indicate the median. Lowercase letters indicate significant differences between the management types $(\mathrm{p}<0.05)$. Sample sizes in (a) CCF: $n=26$, EA: $n=24$, PF: $n=5$. Sample sizes in (b) CCF: $n=22, E A: n=8, P F: n=5$.

Table 4.4: Mean values for Db, Space filling (SF), skewness, ISC, and SSCI for the different species compositions within and between management types. Lowercase letters indicate significant differences in the indices between management types $(\mathrm{p}<0.05)$. For calculation of the SSCI in the even-aged and primary forests, single-scans were used. Therefore, only the beech forests were included in the analysis for EA, as the single-scans for the other tree species and compositions were not available.

\begin{tabular}{ccccccccc}
\hline Index & $\begin{array}{c}\text { CCF } \\
\text { broadleaved }\end{array}$ & $\begin{array}{c}\text { CCF } \\
\text { coniferous }\end{array}$ & $\begin{array}{c}\text { CCF } \\
\text { mixed }\end{array}$ & $\begin{array}{c}\text { EA } \\
\text { mixed }\end{array}$ & $\begin{array}{c}\text { EA } \\
\text { spruce }\end{array}$ & $\begin{array}{c}\text { EA } \\
\text { pine }\end{array}$ & $\begin{array}{c}\text { EA } \\
\text { beech }\end{array}$ & $\begin{array}{c}\text { PF } \\
\text { beech }\end{array}$ \\
\hline $\mathbf{D b}$ & $2.33^{\mathrm{b}}$ & $2.37^{\mathrm{ab}}$ & $2.38^{\mathrm{ab}}$ & $2.26^{\mathrm{b}}$ & $2.33^{\mathrm{b}}$ & $2.17^{\mathrm{c}}$ & $2.29^{\mathrm{b}}$ & $2.43^{\mathrm{a}}$ \\
$\mathbf{S F}$ & $8.38^{\mathrm{a}}$ & $6.66^{\mathrm{a}}$ & $8.97^{\mathrm{a}}$ & $6.92^{\mathrm{a}}$ & $7.88^{\mathrm{a}}$ & $5.16^{\mathrm{a}}$ & $7.20^{\mathrm{a}}$ & $5.80^{\mathrm{a}}$ \\
$\mathbf{S k e w}$ & $0.06^{\mathrm{a}}$ & $0.66^{\mathrm{bc}}$ & $0.66^{\mathrm{c}}$ & $-0.64^{\mathrm{b}}$ & $-0.52^{\mathrm{bc}}$ & $-0.99^{\mathrm{a}}$ & $-0.39^{\mathrm{a}}$ & $0.06^{\mathrm{a}}$ \\
$\mathbf{I S C}$ & $0.76^{\mathrm{a}}$ & $0.79^{\mathrm{ab}}$ & $0.79^{\mathrm{ab}}$ & $0.44^{\mathrm{bc}}$ & $0.52^{\mathrm{c}}$ & $0.30^{\mathrm{c}}$ & $0.57^{\mathrm{bc}}$ & $0.80^{\mathrm{a}}$ \\
$\mathbf{S S C I}$ & $6.25^{\mathrm{a}}$ & $6.13^{\mathrm{a}}$ & $7.03^{\mathrm{a}}$ & - & - & - & $4.59^{\mathrm{b}}$ & $5.95^{\mathrm{a}}$ \\
\hline
\end{tabular}




\subsection{Discussion}

\subsubsection{Quantifying the target structure of CCF stands}

In this study, we tested whether the structure of CCF stands in the target stage can be quantitatively separated from even-aged stands. We used three structural measures $\left(D_{b}\right.$, space filling, and its skewness) derived from terrestrial laser scanning (TLS) and a TLSbased index (SSCI), which was introduced recently (Ehbrecht et al. 2017). We further tested a new index (ISC), which combines $\mathrm{D}_{\mathrm{b}}$ and skewness of space filling. This index aims to integrate three main structural attributes: the box dimension, which quantifies stand structural complexity based on fractal analysis (Seidel 2018), the skewness of space filling, and stand height. While the box dimension is a powerful tool and accounts for forest density, its disadvantage is that it cannot indicate in which direction the distribution of aboveground plant material deviates from a hypothetical even distribution in space. This disadvantage is compensated for by inclusion of the skewness of space filling into the index construction. Combining structural attributes is an appropriate way to reliably distinguish between different management types (Schall et al. 2018b). As shown in Fig. 4.6, combining skewness of space filling with box dimension seems to be a suitable approach. According to McElhinny et al. (2005) every index for structural complexity should take a set of several stand structural attributes into account, which are then linked together as simply as possible in the index construction. The idea of using quantification of the structure of CCF target stands was based on the assumption that plant material is vertically homogeneously distributed in natural or near natural forests of the temperate zone, where light is the most limiting factor (Davi et al. 2008). This view follows Möller's (1922) early call for a state of equilibrium of plant material in space and time (Hofmann 2010). Thus, in any CCF target stand, plant material should be as homogeneously distributed as possible, irrespective of stand density.

Here we showed that the new index was able to distinguish quantitatively between forest management types, confirming our second hypothesis. It clearly separated CCF-target stands from EA-stands. SSCI also led to detection of significant differences between EAforests and CCF target stands. However, in contrast to SSCI, the ISC values of the CCF target stands and those of the EA-stands did not overlap, which may make it possible to define a threshold value for a CCF target structures in the future (based on a larger database of scanned stands). The finding that mixed and beech-dominated EA-stands were not significantly different in ISC from the coniferous CCF indicates that they may 
already be in a state of transition between traditional and continuous cover management. This can also be seen in Fig. 4.6, which shows slightly overlapping boundaries of the different management systems for non-weighted $D_{b}$ and skewness of space filling.

The ISC describes the resemblance of a forest to a spatially evenly distributed stand based on a simple measure ranging between zero and one. The index would tend towards zero in forests with strong dominance of a single vertical stand layer, such as single-layered "vault-like" forests without any understory. A different example of low values would be thickets with only scattered overstory-trees. If there were no overstory-trees left in the latter, the Chapman-Richards function of the weighted height would reduce the resulting index value. The lowest index values in this study were found in single-layered monocultures of Scots pine (ISC $=0.071 ; 0.090 ; 0.208$ ). The highest index value was found in a CCF stand in Lensahn (ISC $=0.863$ ). This indicates a fairly homogeneous vertical and horizontal distribution of plant material with slight disproportionality in space filling of the lower stand layers in the latter stand (Fig. 4.5, 4.6 and Fig. 4.7a).

We found no significant differences within the CCF stands irrespective of the dominant class of species (coniferous versus broadleaved). However, all CCF stands investigated here are mixed stands, which are known to have higher structural complexity (Juchheim et al. 2019) than pure stands, most likely because of complementary spatial niche occupation (Pretzsch 2014, Ammer 2019). Establishing and maintaining a certain degree of mixture is an essential part of silvicultural concepts such as "close-to-nature" or “continuous cover" (Brang et al. 2014, Schütz 2002, and Pommerening and Murphy 2004). Nevertheless, shade-tolerant tree species such as European beech can develop complex structures even in pure stands. This is seen in the high values of the primary forests, composed of more than $95 \%$ beech, and the even aged-pure beech stands of our study, neither of which differed significantly in their mean ISC values from that of the coniferous CCF target stands.

\subsubsection{Structural elements of CCF target stands}

As can been seen from Figure 4.5, it is not space filling that makes the CCF target stands and primary forests similar to one another and different from the EA-forests, but the skewness of space filling with respect to the $\mathrm{D}_{b}$ (Fig. 4.6). This is underscored by the finding that space filling of the primary forests was significantly lower than that of the CCF target stands. Overall, CCF target stands and primary beech forests showed much less deviation from homogeneously distributed space filling than EA-stands (Fig. 4.4 and 
Tab. 4.2). In contrast to the EA-stands, neither CCF target stands nor primary beech forests were significantly different in the mean deviation of space filling from an evenly homogenous distribution of plant material, confirming our first hypothesis. The EAstands, however, differed not only in the degree of deviation of plant material (here voxels) but also in the 'direction' of deviation (see Fig. 4.4 and Tab. 4.2).

Interestingly, $\mathrm{CCF}$ target stands could be statistically significantly distinguished from EA in a number of tested structural measures. $\mathrm{D}_{\mathrm{b}}$, Gini-coefficient, skewness and coefficient of variation of space filling between the vertical layers and vertical evenness values differed between management types (Tab. 4.3). The lowest values in both $\mathrm{D}_{\mathrm{b}}$ and space filling were found in even-aged monocultures of Scots pine. These stands were located outside the $75 \%$-quantile of the CCF target stands and differed significantly in structure from the latter. The same was found for skewness of space filling (Fig. 4.5c). While evenaged Scots pine forests differed from CCF target stands in all structural indices considered here, $\mathrm{D}_{\mathrm{b}}$ and space filling of even-aged monocultures of Norway spruce overlapped somewhat with the values of CCF target stands (Fig. 4.5a and 4.5b). This may be attributed to the higher foliage density and crown length of Norway spruce, which is more shade-tolerant than Scots pine. In the case of even-aged Norway spruce stands, skewness was decisive for separation from the CCF target stands (Fig. 4.5c). This also applied to the mixed EA-stands and EA-forest stands dominated by European beech. The skewnessvalues of the even-aged forests were exclusively negative. This indicated single-layered stands with clear dominance of the upper canopy layers. In contrast, the mean positive skewness of the CCF target stands reflected the multi-layered nature of CCF target stands (Tab. 4.3; Guericke \& Gaffron 2010, Zingg 2003). Thus, skewness is a suitable measure to distinguish the structure of CCF target stands from even-aged forest stands.

$\mathrm{D}_{\mathrm{b}}$, space filling and skewness were highly variable between CCF study areas (Fig. 4.5 and Tab. 4.3). This can be explained in part by the structural differences in the tree species involved, but there are also large variations between forests composed of single species. Apart from species-based variability, therefore, this could be an indication of a heterogeneous horizontal structure. However, in our stands this was not the case since variation in horizontal evenness within CCF target stands was low (Tab. 4.3). We found no significant differences at the horizontal level between management types, which was unexpected; numerous authors had identified horizontal heterogeneity as an important structural property of CCF (Kraut 2010, Stähr and Müller 2010). It may be, therefore, that 
we were not able to capture horizontal heterogeneity adequately in this study. We assume that a reliable estimation of this structural measure would have required larger plots than the $40 \times 40 \mathrm{~m}$ used here.

\subsection{Conclusions}

In this study, we confirmed numerous structural characteristics of CCF target stands that had been addressed by others as well. Most of the CCF target stands showed only a small right skewed deviation from the homogeneous vertical distribution of biomass, and this was in favor of the lower stand layers. This means that the stands are multi-layered. This structure is in part the outcome of competition within cohorts of the same age, but also results from ongoing regeneration processes leading to different age classes occurring next to each other, as noted in Möller's (1922) concept.

It seems as if ISC, the new index suggested here, is a suitable tool to objectively quantify the specific forest structures of CCF target stands that distinguish them from even-aged stands. This study has once again highlighted the enormous range of possible applications of TLS. We are not aware of any other methods that provide objective and quantitative data on the vertical and horizontal spatial distributions of plant material. Therefore, in future studies of forest structures and their structural complexity, TLS will play an important role in obtaining detailed and objective data.

Comparing the three-dimensional structural complexity of CCF target stands and the European beech primary forests considered here, it can be concluded that the CCF concept can lead to structural complexity similar to that of natural, i.e., unmanaged European beech forests. It is assumed that structural complex forests are more resilient to climate change (Brang et al. 2014), but this remains to be seen (O'Hara 2016). Moreover, several studies suggest that structural diversity is a main driver of stand productivity (Hardiman et al. 2011, Ishii et al. 2004, and Dănescu et al. 2016) which can make CCF stands, once they have reached their target structure, a useful approach to forest management. 


\subsection{Acknowledgements}

The Dr. Erich Ritter-Foundation (T0021/29427/2017) is greatly acknowledged for funding this work. The German Science Foundation through grant SE2383/5-1 also funded part of this work. First, we thank Hans von der Goltz representative for all members of the "ANW - Arbeitsgemeinschaft naturnaher Waldbau" that helped us getting in contact with forest owners and their forest administrations. Further, we thank all persons that gave us access to the forest districts they are responsible for and helped us in selection of suitable plots: Ulf and Axel Köhn representative for the "Herzoglich Oldenburgische Forstverwaltung", Tobias Elflein as representative for the "von Rotenhan'sche Forstverwaltung", Simon Stahl as representative for the county administration Freudenstadt, Ernst-Ludwig Kriep as representative for "Stadtwald Gießen", Dirk Röller as representative of the "Graf von Walderdorff'sche Verwaltung" and Martin Fritzenwenger as forest owner of the forest plots located near Teisendorf. Additionally, we thank all people responsible for the study areas used here as references: Dr. Thomas Schmidt-Langenhorst, Sabine Steinhoff, Axel Pampe, Manfred Großmann, Peter Jaloviar, Vasyl Lavnyy and Myroslav Kabal. Permits for accessing the primary forests and fieldwork were issued by the responsible environmental protection office in Presov and administration of "Poloniny National park" for Slovakia and Carpathian Biosphere Reserve for Ukraine. We are grateful to Kathy Regan, USA, for linguistic corrections.

\subsection{References}

Ammer, C. (2019): Diversity and forest productivity in a changing climate. New Phytologist, $221(1), 50-66$.

Bendel, R.B., Higgins, S.S., Teberg, J.E., Pyke, D.A. (1989): Comparisons of skewness coefficient, coefficient of variation, and Gini coefficient as inequality measures within populations. Oecologia, 78 (3), 394-400.

Brang, P., Spathelf, P., Larsen, J. B., Bauhus, J., Boncčìna, A., Chauvin, C., ... \& Lexer, M. J. (2014). Suitability of close-to-nature silviculture for adapting temperate European forests to climate change. Forestry: An International Journal of Forest Research, 87 (4), 492-503.

Bode, W. (1992): Einführung von Wilhelm Bode. Der Dauerwaldgedanke. Sein Sinn und seine Bedeutung von Alfred Möller mit einer Einführung von Wilhelm Bode. Erich Degreif Verlag, Oberteuringen. S. 7-21. 
Dănescu, A., Albrecht, A. T., \& Bauhus, J. (2016): Structural diversity promotes productivity of mixed, uneven-aged forests in southwestern Germany. Oecologia, 182 (2), 319-333.

Davi, H., Baret, F., Huc, R., Dufrene, E. (2008): Effect of thinning on LAI variance in heterogeneous forests. Forest Ecology and Management, 256 (5), 890-899.

Ehbrecht, M., Schall, P., Juchheim, J., Ammer, C., Seidel, D. (2016): Effective number of layers: A new measure for quantifying three-dimensional stand structure based on sampling with terrestrial LiDAR. Forest Ecology and Management 380, 212-223.

Ehbrecht, M., Schall, P., Ammer, C., Seidel, D. (2017): Quantifying stand structural complexity and its relationship with forest management, tree species diversity and microclimate. Agricultural and Forest Meteorology 242, 1-9.

Felipe-Lucia, M.R., Soliveres, S., Penone, C., Manning, P., van der Plas, F., Boch, S., ... $\&$ Bauhus, J. (2018): Multiple forest attributes underpin the supply of multiple ecosystem services. Nature communications, 9 (1), 1-11.

Fritzlar, D., Biehl, H. (2006): Buchenplenterwald Hainich-Creuzburg: Buchenzentrum Mühlhausen.

Guericke, M., Gaffron, H. (2010): Entwicklung strukturreicher Mischwälder am Beispiel der Lehroberförsterei Chorin, u.a. des Dauerwaldblockes Groß Ziethen. Naturnahe Waldwirtschaft - Dauerwald heute? Eberswalder Forstliche Schriftenreihe, Landeskompetenzzentrum Forst Eberswalde (Hrsg.), Bd. 46. S. 48-54.

Gustaffson, L., Baker, S.C., Bauhus, J., Beese, W.J., Brodie, A., Kouki, J., ... \& Neyland, M. (2012): Retention forestry to maintain multifunctional forests: a world perspective. BioScience, 62 (7), 633-645.

Hardiman, B.S., Bohrer, G., Gough, C.M., Vogel, C.S., Curtis, P.S. (2011): The role of canopy structural complexity in wood net primary production of a maturing northern deciduous forest. Ecology, 92 (9), 1818-1827.

Hofmann, G. (2010): Alfred Möller - Wegweiser in die Waldzukunft. Herausgegeben von: Ministerium für Infrastruktur und Landwirtschaft des Landes Brandenburg (2010): Naturnahe Waldwirtschaft - Dauerwald heute? Eberswalder Forstliche Schriftenreihe, Band 46, S. 58-63.

Ishii, H.T., Tanabe, S.-I., Hiura, T. (2004): Exploring the relationships among canopy structure, stand productivity, and biodiversity of temperate forest ecosystems. Forest Science 50 (30), 342-355. 
Juchheim, J., Ammer, C., Schall, P., Seidel, D. (2017): Canopy space filling rather than conventional measures of structural diversity explains productivity of beech stands. Forest Ecology and Management, 395, 19-26.

Juchheim, J., Ehbrecht, M., Schall, P., Ammer, C., Seidel, D. (2019): Effect of tree species mixing on stand structural complexity. Forestry, 0, 1-9.

Kraut, H. (2010): Naturnahe Waldbewirtschaftung - tragfähiges Konzept eines effektiv arbeitenden Landesforstbetriebes? Herausgegeben vom: Ministerium für Infrastruktur und Landwirtschaft des Landes Brandenburg (2010): Naturnahe Waldwirtschaft Dauerwald heute? Eberswalder Forstliche Schriftenreihe, Band 46, 55-57.

Kuuluvainen, T. (2009): Forest Management and Biodiversity conservation based on natural ecosystem dynamics in northern Europe: The complexity challenge. Ambio: A Journal of the Human Environment, 38 (6), 309-315.

Lüpke, Bv., Ammer, C., Braciamacchie, M., Brunner, A., Ceitel, J. Collet, C., ... \& Zientarski, J. (2004): Silvicultural strategies for conversion. In: Spiecker, H., Hansen, J., Klimo, E., Skovsgaard, J.P., Sterba, H., Teuffel, K. (eds): Norway spruce conversion - options and consequences. European Forest Institute Research Report 18. Leiden, Boston: Brill. 121164.

McElhinny, C., Gibbons, P., Brack, C., Bauhus, J. (2005): Forest and woodland stand structural complexity: Its definition and measurement. Forest Ecology and Management 218, 1-24.

Mizunaga, H., Nagaike, T., Yoshida, T., Valkonen, S. (2010): Feasability of silviculture for complex stand structures: designing stand structures for sustainability and multiple objects. Journal of Forest Research, 15, 1-2.

Möller, A. (1920): Kiefern-Dauerwaldwirtschaft - Untersuchungen aus der Forst des Kammerherrn von Kalitsch in Bärenthoren. Zeitschrift für Forst und Jagdwesen, 52, 441.

Möller, A. (1922): Der Dauerwaldgedanke. Sein Sinn und seine Bedeutung. Springer Verlag, Berlin.

Nagel, T.A., Zenner, E.K., Brang, P. (2013): Research in old-growth forests and forest reserves: implications for integrated forest management. Integrative approaches as an opportunity for the conservation of forest biodiversity. Freiburg: European Forest Institute, 44-50.

O'Hara, K.L. (2001): The silviculture of transformation - a commentary. Forest Ecology and Management, 151, 81-86.

O’Hara, K.L., Hasenauer, H., Kindermann, G. (2007): Sustainability in multi-aged stands: an analysis of long-term planter systems. Forestry, 80 (2), 163-181. 


\section{Chapter 4}

O'Hara, K.L. (2016): What is close-to-nature-silviculture in a changing world? Forestry, 89, 1-6.

Pommerening, A., Murphy, S.T. (2004): A review of the history, definitions and methods of continuous cover forestry with special attention to afforestation and restocking. Forestry, 77 (1), 27-44.

Pretzsch, H. (2014). Canopy space filling and tree crown morphology in mixed-species stands compared with monocultures. Forest Ecology and Management, 327, 251-264.

Pukkala, T. (2016): Plenterwald, Dauerwald or clearcut? Forest Policy and Economics, 62, 125134.

R Core Team (2017): R: A language and environment for statistical computing. R Foundation for Statistical Computing, Vienna, Austria. URL https://www.R-project.org/.

Schabel, H.G., Palmer, S.L. (1999): The Dauerwald: Its role in the restoration of natural forests. Journal of forestry, 97 (11), 20-25.

Schall, P., Gossner, M. M., Heinrichs, S., Fischer, M., Boch, S., Prati, D., .. \& Buscot, F. (2018a): The impact of even-aged and uneven-aged forest management on regional biodiversity of multiple taxa in European beech forests. Journal of applied ecology, 55 (1), 267-278.

Schall, P., Schulze, E. D., Fischer, M., Ayasse, M., \& Ammer, C. (2018b): Relations between forest management, stand structure and productivity across different types of Central European forests. Basic and Applied Ecology, 32, 39-52.

Schmidt, U.E. (2009): Wie erfolgreich war das Dauerwaldkonzept bislang: eine historische Analyse. Schweiz. Z. Forstwes., 160 (6), 144-151.

Schütz, J.-P. (1999b): Close-to-nature silviculture: is this concept compatible with species diversity? Forestry, 72 (4), 359-366.

Schütz, J.-P. (2002): Silvicultural tools to develop irregular and diverse forest structures. Forestry, 75 (4), 329-337.

Seidel, D., Leuschner, C., Scherber, C., Beyer, F., Wommelsdorf, T., Cashman, M. J., \& Fehrmann, L. (2013): The relationship between tree species richness, canopy space exploration and productivity in a temperate broad-leaf mixed forest. Forest Ecology and Management, 310, 366-374.

Seidel, D. (2018): A holistic approach to determine tree structural complexity based on laser scanning data and fractal analysis. Ecology and Evolution 2018, 8: 128-134.

Seidel, D., Ehbrecht, M., Annighöfer, P., Ammer, C. (2019a): From tree to stand-level structural complexity - Which properties make a forest stand complex? Agricultural and Forest Meteorology, 278, 107699. 
Seidel, D., Annighöfer, P., Stiers, M., Zemp, C.D., Burkhardt, K., Ehbrecht, M., Willim, K., Kreft, H., Hölscher, D., Ammer, C. (2019b): How a measure of tree structural complexity relates to achitectural benefit-to-cost ratio, light availability, and growth of trees. Ecology and Evolution 2019, 00: 1-9.

Stähr, F., Müller, M. (2010): Der Dauerwaldgedanke - seine waldwirtschaftlichen Hintergründe und Visionen. Herausgegeben vom: Ministerium für Infrastruktur und Landwirtschaft des Landes Brandenburg (2010): Naturnahe Waldwirtschaft - Dauerwald heute? Eberswalder Forstliche Schriftenreihe, Band 46, S. 7-12.

Stiers, M., Willim, K., Seidel, D., Ehbrecht, M., Kabal, M., Ammer, C., Annighöfer, P. (2018): A quantitative comparison of the structural complexity of managed, lately unmanaged and primary European beech (Fagus sylvatica L.) forests. Forest Ecology and Management 430, 357-365.

Willim, K., Stiers, M., Annighöfer, P., Ammer, C., Ehbrecht, M., Kabal, M., Stillhard, J., Seidel, D. (2019): Assessing understory complexity in beech-dominated Forests (Fagus sylvatica L.)-from managed to primary forests. Sensors 2019, 19, 1684.

Zeileis, A., Kleiber, C., Zeileis, M.A. (2009): Package „ineq“. Tech. Rep.

Zingg, A. (2003): Dauerwald - ein neues altes Thema der Waldwachstumsforschung. Informationsblatt Forschungsbereich Wald 15/2003, 42-45. 
Chapter 5

Synthesis 


\section{Synthesis}

This chapter aims at summarizing, discussing and relating the three presented studies. In addition, it will be examined whether the main objectives underlying this doctoral thesis have been achieved. For this reason, we have studied the structural complexity from various points of view. Overall, we were able to conclude that specific management systems and interventions can significantly increase the structural complexity of forest stands. The results presented here provide the framework for management recommendations that promote structural complexity in managed forests.

In the three presented studies, terrestrial laser scanning has again shown its large potential as an efficient approach to generate quantitative, objective, reliable and detailed data to describe forest structure and stand structural complexity. Based on the comparison of stand structural complexity derived from laser-scanning data, we were able to determine significant structural differences between differently managed forest stands of beech (chapter 2, Fig. 2.3), which indicates that forest management significantly affects stand structural complexity in beech-dominated forests. Thus, we found evidence that support the first leading hypothesis (I) that forest management results in significant differences in forest structure and stand structural complexity along a gradient of management intensity in forests of European beech.

Beside the influence of forest management, natural drivers of structural complexity could be identified. For example, there were significant structural differences between the phases of stand development (chapter 2) and a significant correlation between the sizes of regeneration patches and canopy gaps, which expresses the importance of light availability for vertical diversification (chapter 3). It was further possible to identify a significant top-down-dependency between canopy gaps and understory complexity, as well as specific spatial regeneration patterns for European beech, which contributes to a better understanding of regeneration ecology and provides evidence to support the second leading hypothesis (II).

Furthermore, in answering the question, whether forest management leads to a simplification or diversification of forest structural complexity, we were able to determine that stand structural complexity is not mandatorily decreased by forest management. On the one hand, traditional management systems especially promote the structure in younger (0-20 years) and mature (81-120 years) stand developmental phases, but only rarely reached the level of structural complexity found in primary forests (chapter 2). On the 
other hand, close-to-nature management systems, such as continuous cover forestry, are able to create structures and structural complexity as high as in primary beech forests (chapter 4). Therefore, we were able to reject the third leading hypothesis (III).

\subsection{Comparisons of stand structural complexity between differently managed forests}

To analyze and quantify the effects of management on forest ecosystems, it is helpful and necessary to use natural references. Natural or near-natural forests are commonly associated with high structural diversity and heterogeneity. However, forest structure in natural forest development is not static (Fig. 1.1), but undergoes various stages of structural complexity. In this context, we identified four main factors that must be considered when comparing forest structure.

Many forests in the temperate zone naturally tend towards homogenization within the natural developmental dynamics (Schütz 2002). On the one hand, this is due to the high competitive power of individual tree species, such as European beech, which then leads to the formation of predominantly pure stands. On the other hand, in the progress of stand development, growth leads to a state of canopy closure, which in the case of beech lasts particularly long. Additionally, beech forest canopies are often particularly dense due to the high crown plasticity of the species (Feldmann et al. 2018a). The first important factor for comparisons of structural complexity is therefore the tree species, since each tree species has its own dynamic in stand development.

The comparatively high canopy closure in beech forests causes them to be naturally single-layered for a long time, which then results in so-called "vault-like" forests, which are typical for beech forests in the optimum phase. This could also be confirmed for a large part of study areas dominated by beech investigated here (chapter 2). The exception in which heterogeneous and irregular structures develop naturally in beech forests is the decay phase (Schütz 2002). However, it is not possible to determine exactly when a forest stand enters the decay phase since it depends on age, tree species and mixture, site and climatic conditions and stand history. Here, we analyzed stand structural complexity in two completely unmanaged primary beech forests of different age. Our results showed that the forest of Rožok, in which the oldest trees had an estimated age of $~ 220$ years was significantly less complex than the $\sim 350$-year-old forest in Uholka, but more complex than the lately unmanaged National parks with a stand age of 180 years. This indicates 
that stand structural complexity of beech forests starts to increase at an age of about 200 years (chapter 2, Figs. 2.5 and 2.6). Thus, it can be assumed that natural decay in natural beech forests is beginning around this age. Hence, the actual developmental phase is a crucial factor when comparing stand structural complexity of forests.

Another factor to consider is the spatial scale at which the comparison is done. While small-scale heterogeneity due to a small-scale mosaic of all developmental phases is attributed to primary or near-natural forests (Podlaski et al. 2019), the developmental phases in traditional management systems coexist stand-wise on a larger spatial scale. Most studies comparing managed and unmanaged forests used only one of these developmental phases, but all developmental phases have to be included into the analysis (Schall et al. 2018). Therefore, in the investigation of the traditional and alternative management systems, we include four successive developmental phases, respectively. We found significant differences between these phases of stand development, indicating a significant influence of stand age on forest structure and structural complexity. This contributes to the explanation of the differences in structural complexity between the differently managed stands. The significantly lowest stand structural complexity was found in the National parks. While the managed stands cover all developmental phases except natural decay and thus, cover higher complexity in younger stand ages, the lately unmanaged National parks consist exclusively of beech forests in the optimum phase, where structural complexity is low (chapter 2, Figs. 2.4 and 2.5).

Yet another factor to be taken into account when comparing the structural complexity of forests is the stand history. Thus, the structural differences between the primary forests Rožok and Uholka can possibly be explained by their developmental history and their disturbance regime. While the heterogeneous forest structure in Uholka indicates smallscale regeneration, Rožok is characterized by trees of the same age over large areas (chapter 2). According to Nagel et al. (2006, 2014, 2017) and Jaloviar et al. (2017) these structures may indicate large-scale disturbances, such as storms in the past, which initiate even-aged regeneration at larger scales (Fig. 5.2). In addition, differences in SSCI between the managed study sites in the age class 81-120 years could be observed (SSCI = Hann Münden: 6.43, Reinhausen: 4.89, Ebrach: 5.67, Lübeck: 5.02). These were mainly caused by the different management methods applied there and cannot be explained without considering the former management. 


\subsection{Canopy closure and its relation to structural complexity}

Differences in canopy closure between the phases of stand development can be identified. Since we have already shown that canopy closure is of great importance for vertical diversification and stratification, this explains the effect of stand age on stand structural complexity. In even-aged pure stands, without artificial or natural disturbances, canopy closure usually increases from the regeneration phase until it reaches its maximum at the beginning of the natural thinning process, lasting until the late optimum phase and then decreases again at the beginning of natural decay when overstory elements disintegrate and canopy gaps form (McElhinny et al. 2005, Franklin et al. 2002). The SSCI showed that the development of stand structural complexity proceeds contrary to this progress of canopy closure; it first decreases until it reaches its minimum in the optimum phase and then increases once the stand enters the decay phase (chapter 2, Fig. 2.6).

As we have seen, the control of canopy closure is highly important for modifying forest structure and structural complexity especially in forests dominated by European beech. Since the importance of canopy gaps is known not only as structural features but also as regulating factor, there are many gap studies (e.g. Bottero et al. 2011, Hobi et al. 2015). However, there are only few studies that deal with the spatial relationships between upper and lower stand layers, which was the main objective of chapter 3 and thus can help to gain a better understanding of how management can influence the lower stand layers by creating canopy gaps. Thus, the results can help to better understand the dynamics of structural complexity and the top-down dependency of structural development. Here, we decided not to compare different age classes and developmental phases as the significant influence of stand age on forest structure and structural complexity have already been shown (chapter 2). Instead, these analyses are solely based on data from mature stands, because the establishment of regeneration in this developmental phase is particularly important for the future state of structural complexity.

Regulating canopy closure means nothing more than regulating the amount of light available in the lower strata. In addition to this direct influence on light availability, management also indirectly affects the availability of water and nutrients as well as the competition strength by lowering the stand basal area. Management interventions thus influence the establishment of vertical layers, which is determined by not only the size of canopy gaps but also by their shape and distribution. Different tree species show varying responses to varying amounts of light availability due to differently sized and shaped 
gaps. European beech is known for its particularly high shade tolerance (e.g. Petriţan et al. 2009, Petriţan et al. 2011), which was again confirmed here. For beech, it was found that the strength of top-down dependency is rather low, which means that beech regeneration has established even in small canopy gaps where no direct light was available. Accordingly, it was found that even diffuse light in the transition zone between the gap and the adjacent stand, the so-called penumbral zone, is sufficient to promote natural regeneration of beech (chapter 3). Nevertheless, we found a significant positive relationship between gap area and regeneration area. Furthermore, we were able to identify a general pattern of spatial distribution of beech regeneration heights based on a top-down-analysis showing that regeneration of beech is highest in mid-gap positions (chapter 3). All these spatial relationships were independent of the type of management, which once again confirms that forest structure is also influenced by other factors, regardless of management intensity.

\subsection{Continuous cover forestry as special type of close-to-nature forestry}

One common form of close-to-nature forestry is continuous cover forestry (chapter 4, e.g. Pommerening and Murphy 2004). Here, great importance is given again to canopy closure, whereby "continuous cover" primarily refers to the continuity of cover, i.e. the total avoidance of clear cutting. The continuity of the forest refers not only to canopy closure, but also to all subsystems and components related to the forest ecosystem, including the forest structure and structural complexity. This structural constancy results in a targeted state of equilibrium, to which high multifunctionality, resilience and adaption are attributed. In order to objectively quantify this structural constancy, we introduced the laser-scanning-based index for structural constancy (ISC) based on assumptions on horizontal and vertical forest structure of continuous cover forests (chapter 4). The ISC estimates the degree of similarity of a forest stand with the hypothesized target state of structural constancy based on the $\mathrm{D}_{\mathrm{b}}$, Skewness and stand height, while $D_{b}$ and Skewness in combination are suitable for describing the spatial distribution of biomass within a forest stand. Therefore, we are returning to the importance of canopy closure and thus the availability of light within the different stand layers for the establishment of a multi-layered structure, which in turn increases the structural complexity of a forest. 


\subsection{Ceasing or intensifying forest management to promote structural complexity?}

In the discussion on the integration of nature conservation into forest management, the approach applied depends largely on the objectives that have been set. To create refuges of natural forest development and to promote the associated habitats, forest management has been ceased on several forest areas. These strict forest reserves or national parks serve as observation areas and references for natural development and forest dynamics (Meyer 2005). Since highly heterogeneous and structural diverse forests are attributed to be less vulnerable to disturbances, a global challenge for foresters and forest sciences is to focus on the promotion of stand structural complexity and structural heterogeneity to create more resilient and adaptive forest ecosystems (e.g. Puettmann 2011, Seidl et al. 2011a, and Lafond et al. 2014). Thus, if the aim is to increase heterogeneity and thus stand structural complexity in forests, ceasing forest management does not initially lead to the desired target state of high structural complexity. Even after a period of 30 years with no management, structures in the unmanaged National parks are still vastly different from primary forests (chapter 2). According to Sabatini et al. (2018) and Meyer (2005), it often takes several decades for lately unmanaged forests to develop structures similar to primary forests, which in turn depends on the age at which management has been ceased. Nevertheless, they provide an important contribution to the protection of natural development, which is particularly important to analyze and evaluate the resistance, resilience and regeneration of forest ecosystems.

To answer the question whether or not forest management is suitable to increase structural complexity a distinction should be made between different types of management, since we were able to determine that specific management types are suitable to promote and increase structural complexity, while others are not (e.g. Schulze et al. 2014). In this study, we differentiated between traditional and alternative forest management systems, but we could not detect any significant difference between them (chapters 2 and 3), which is why we decided to summarize them more generally as even-aged managed stands in chapter 4. Individual stands consist mainly of trees of one developmental phase. In answering the question of the direction of management effects, it is furthermore decisive which reference is used for comparison. For example, several studies found that forest management decreases forest structure (e.g. Liira et al. 2007, Okuda et al. 2003). Contrary, we found that target-diameter harvesting in the even-aged managed stands could increase structural complexity due to the creation of canopy openings and thus 
vertical heterogeneity compared to lately unmanaged forests with closed canopy during the optimum phase (chapter 2). This type of forest management thus not only disperses canopy closure in mature stands, but also creates structurally rich stands of younger developmental phases, e.g. thickets with scattered overstory trees. These highly complex thickets can provide important habitats and thus promote biodiversity compared to other less structured developmental phases. Although traditional management is therefore able to increase structural complexity when compared to lately unmanaged stands, where forest management was ceased, it does not generally create structural complexity on the same level as primary forests (chapter 2, Fig. 2.3).

Another possibility that is discussed to increase structural complexity in forest ecosystems is to intensify forest management (e.g. Puettmann 2011). However, Lafond et al. (2014) and Storch et al. (2019) have found that the intensification of forest management and harvesting beyond a certain threshold reduces structural diversity and stand stability. This will be further discussed in the section on management recommendations (chapter 5.6). Thus, neither intensifying nor ceasing forest management are suitable tools to increase the structural complexity of forests in general and on a large scale. In addition to the set-aside forests and the intensification of timber harvesting, there is a need for management practices that can be applied to increase structural complexity on a larger scale. One alternative management method, which is mainly discussed in this context, is close-to-nature forestry. Among other goals it aims at further increasing the structural complexity in managed forests and can thus contribute to achieve nature conservation goals, while harvesting timber on the same area. Numerous studies showed that such close-to-nature approaches, aiming at multifunctional forests, are not incompatible with nature conservation and timber production (Felipe-Lucia et al. 2018). Furthermore, several studies concluded that forests managed with focus on multifunctionality and the promotion of diversity can have a more positive impact on biodiversity than ceasing forest management (e.g. Gustafsson et al. 2012, Puettmann et al. 2012, Schall et al. 2018, and Schütz 1999b).

Based on the results of chapter 2 and 4, we could show that continuous-cover forestry as specific type of close-to-nature forestry is able to create stand structural complexity on a similar level than recorded in primary beech forests (chapter 4 and Fig. 5.1). 


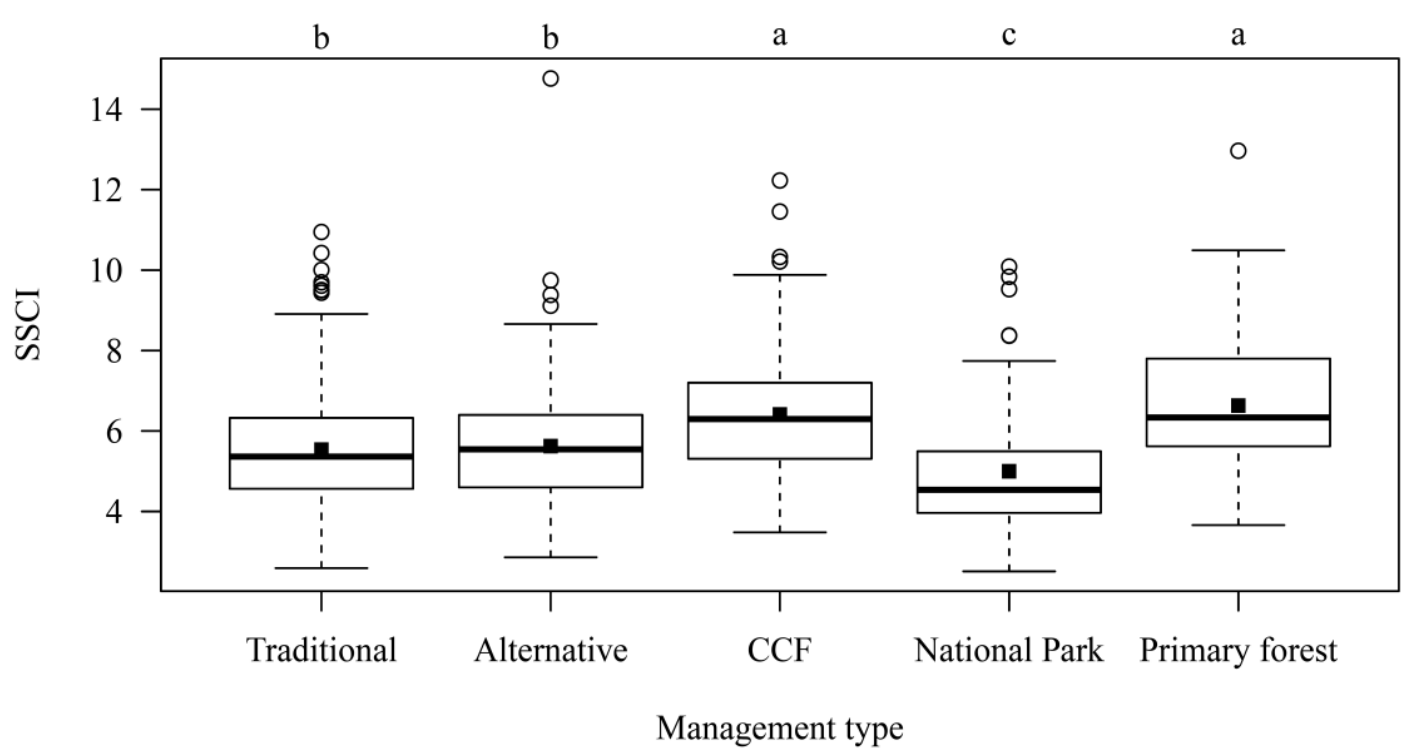

Figure 5.1: Box-whisker plots of the stand structural complexity index (SSCI) over different management types and along a management gradient (from traditionally and alternatively managed beech-dominated stands (chapter 2), managed close-to-nature (CCF), and lately unmanaged National parks to always unmanaged primary forests). Black horizontal lines indicate the median, black squares mark the mean values. ( $\mathrm{n}=240$ for "Traditional" $\mathrm{n}=210$ for "Alternative", $\mathrm{n}=60$ for "National Park" and "Primary forest", $\mathrm{n}=174$ for "CCF”). Different lower-case letters indicate significant differences among the management types at the level of $\mathrm{p}<0.05$. Significant differences were tested by using Kruskal-WallisAnova and pairwise Wilcoxon test.

\subsection{Critical review of the methods applied and outlook for future research}

Considering the results of the studies included here, it must be remembered that they cannot be regarded as being generally valid. Thus, although we were able to generate reliable results for the influence of forest management on forest structure and structural complexity in beech forests in different developmental phases as well as for several CCF forest stands, these results cannot be transferred in the same way to other tree species, sites or climatic conditions. Therefore, it would be an important addition to extend the investigations to other tree species or study areas. It would be particularly interesting to analyze how the effects of forest management on the structural complexity in stands of light-demanding tree species differ from those on shade-tolerant species such as European beech. This would result in an increase in sample size, which is also desirable to obtain statistically highly reliable results. The main limitation of the underlying sample size here was the methodology of the high-effort and time-consuming multi-scans. Future studies should therefore make use of the new possibilities offered by mobile laser scanning 
(MLS), which is much more efficient, but still delivers data in high detail. Thus, MLS allows analyses based on multi-scan clouds to be applied on larger scale in the future.

Forest ecosystems of the temperate zone show a diverse pattern of different stand types dominated by different tree species at different stages of stand development. For comparisons between these different stand types and management systems, the scale on which these comparisons are made is particularly important. In order to integrate all stages of development into the comparison despite their spatial separation in traditional management, we collected data in different stands at different developmental stages for the managed stands (chapter 2). However, the structural comparisons in chapters 3 and 4 are based solely on plot $(\alpha)$ - or stand $(\beta)$-level. It cannot be completely excluded that a comparison on a larger scale would have led to different results in these cases, e.g. Schall et al. (2018) recommend the comparison on landscape $(\gamma)$-scale. This was, once again, not possible here due to the time-consuming multi-scan procedure. Thus, the high potential of MLS for future studies is once more revealed.

Forest structure and structural complexity are not static, but dynamic, which is something that should be accounted for in the quantification. Since trees and forests in general have long developmental periods, it is almost impossible to study their dynamics in real time series. For this reason, instead of real time series often artificial time series are used for comparison, which are composed of different stands in successive developmental stages. This was also applied in this doctoral thesis. Despite the validity and significance of artificial time series, it would still be of great interest to establish permanent observatory plots to study the actual development of forest structures over time.

Another aspect to be considered is the selection of reference systems. Here, we decided to extend the comparisons up to completely unmanaged primary beech forests, but it is questionable whether submontane beech forests in the Carpathian Mountains are at all comparable with german beech forests in lowlands. With regard to genetics, the growing area and its climatic characteristics, there will probably be differences between the primary forests and the german study areas, but by strictly adhering to our plot selection criteria, we tried to keep these as small as possible. However, since there are no primary forests left in Germany and in general primary forest remnants are only very scattered and rare, the primary forests of the Carpathians are the best choice for comparisons with other management systems. 


\subsection{Conclusions and management recommendations}

After several decades of research, the importance of structures and structural complexity for ecosystem functioning and services is well known. The multifunctionality and stability of forests is becoming increasingly important, especially in the wake of climate change and steadily increasing demands on forests. For this reason, there have been many recent results on this topic and the control of structures (e.g. Drever et al. 2006, Kucbel et al. 2012, and Puettmann 2011). As a result, the understanding of how to create and promote forest structures and structural complexity is constantly improving. This study has also contributed to our understanding of the effects of management on forest structure by showing that forest management can have a positive influence on forest structure and structural complexity. Moreover, we were able to determine that continuous cover forestry as specific type of close-to-nature forestry can even create structural complexity similar to those of primary forests. An increase in naturalness and structural complexity of managed forests and the associated promotion of ecosystem functioning can and should be seen as a success of close-to-nature management.

Most studies dealing with deriving management recommendations based their results on the reaction of natural forests to natural disturbances (Fig. 5.2). Management interventions emulating natural disturbances should produce similar effects on stand structure and thus promote a lot of ecosystem functions and services such as allowing for a high conservation level of biodiversity (e.g. Adamic et al. 2017, Kuuluvainen 2009). Those interventions should further emerge differently sized and distributed canopy gap openings (Fig. 5.2), which are closed in different periods. In this way, a mosaic of different developmental phases and thus vertical and horizontal heterogeneity should be created (e.g. Podlaski et al. 2019). Different degrees of canopy closure could not only result in structural heterogeneous forests, but also offer opportunities for different tree species to establish. Mixed forests with a high tree species diversity are one common aim of modern close-to-nature management systems, since they are not only known to build up higher structural complexity (Juchheim et al. 2019), but are also attributed to greater stability and resilience. Nevertheless, especially shade-tolerant tree species as for example European beech are capable of producing structurally highly complex pure stands, as can be seen in the primary forests investigated here, which are nearly exclusively composed of beech. 
Natural disturbance dynamics

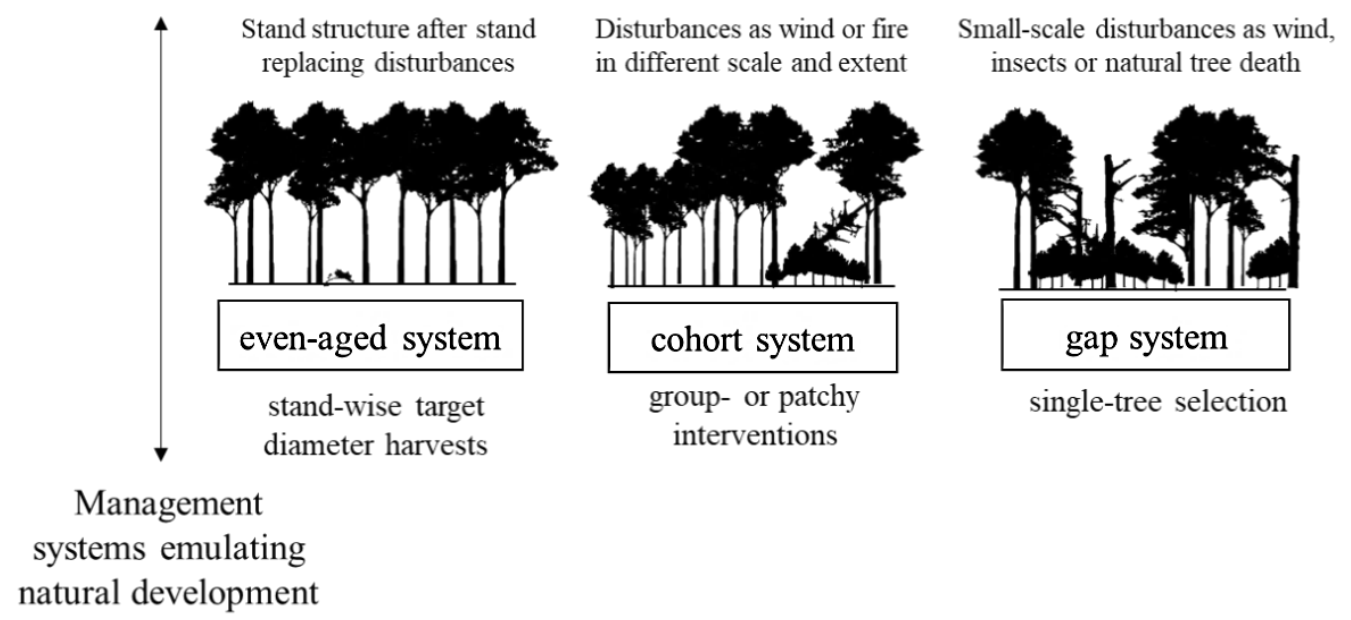

Figure 5.2: An illustration of management systems on stand-level that emulate natural disturbances. Modified after Kimmins (2004) and Kuuluvainen (2009).

Especially in forests which are dominated by those shade-tolerant tree species, the control of canopy closure, i.e. the creation of canopy gaps, is of great importance. It has already been discussed that traditional forest management with highly intense harvests (large shelterwood-systems or high intense harvests up to clear-cuts) often leads to a reduction of structural complexity (Storch et al. 2019) by opening the canopy to such an extent that the natural inner forest climate is destructed or significantly disturbed. In addition, uneven-aged management systems can homogenize the stand structure as well. Examples are regular interventions (in terms of time and space) or gaps created by single-tree harvesting that are too small to allow for the establishment of different tree species and different ages of regeneration (e.g. Adamic et al. 2017, Angers et al. 2005). For this reason, it seems reasonable to perform irregular interventions at different spatial and temporal intervals and intensities (Raymond et al. 2009).

In the search for a suitable management system, the local, ecological and operational conditions should be taken into account. If, for example, it is a matter of establishing admixed tree species, the gap size must be adapted to the light requirements of the target tree species, which means that gaps for establishing oak, for example, must be larger than for beech. For some tree species, the intensity of canopy opening should also be considered in relation to the stability of the stand. Stands of spruce on wind-exposed sites should therefore be carefully thinned, even if this delays the establishment of mixed tree species. Finally, the choice of the appropriate management system always depends on the forest owner and his objectives. If the aim is to increase structural complexity, vertical 
diversification is particularly important. As we were able to prove in the second and fourth chapter of this study, this vertical heterogeneity can increase the overall stand structural complexity in particular. Thus, management interventions should be implemented to promote the multi-layering in managed forests. However, as we have also seen in chapter 2 , the pattern of structural complexity in forests is not static, so that the management system should be chosen according to stand age. In beech forests in the optimum phase, more intensive thinnings should be conducted in order to increase the availability of light and thus enable heterogeneous multi-layering. Thereby, low-quality timber could also be left in the forest to promote structures and habitats of the decay phase. Moreover, Seidel et al. (2019a) have shown that to increase structural complexity on stand level, the complexity of the individual trees should be maximized. An important step in this direction could be to leave scattered, strong habitat trees in the stand, as it is currently being done in several forest administrations.

However, modern forest management systems should not only seek to increase structural complexity and diversity within, but as well between forest stands in order to promote diversity at different spatial scales (Schall et al. 2018). Since the overall aim is not the creation of only one, but several, co-existing forms of heterogeneity, complexity and diversity, modern management systems should combine many different silvicultural tools in order to promote a diversified forest landscape. This seems to be a significant challenge for future forest management (Schütz 2002) and creates the need for further research on management effects on forest structure and structural complexity. 


\subsection{References}

Adamic, M., Diaci,J., Rozman, A., Hladnik, D. (2017): Long-term use of uneven-aged silviculture in mixed mountain Dinaric forests: a comparison of old-growth and managed stands. Forestry, 90, 279-291.

Angers, V.A., Messier, C., Beadet, M., Leduc, A. (2005): Comparing composition and structure in old-growth and harvested (selection and diameter-limit cuts) northern hardwood stands in Quebec. Forest Ecology and Management, 217, 275-293.

Bottero, A., Garbarino, M., Dukic, V., Govedar, Z., Lingua, E., Nagel, T.A., Motta, R. (2011): Gap- phase dynamics in the old-growth forest of Lorn (Bosnia-Herzegovina). Silva Fennica, 45 (5), 875-887.

Drever, C.R., Peterson, G., Messier, C., Bergeron, Y., Flannigan, M. (2006): Can forest management based in natural disturbances maintain ecological resilience? Canadian Journal of Forest Research, 36 (9), 2285-2299.

Feldmann, E., Drößler, L., Hauck, M., Kucbel, S., Pichler, V., Leuschner, C. (2018a): Canopy gaps and tree understory release in a virgin beech forest, Slovakian Carpathians. Forest Ecology and Management, 415-416, 38-46.

Felipe-Lucia, M.R., Soliveres, S., Penone, C., Manning, P., van der Plas, F., Boch, S., ... \& Bauhus, J. (2018): Multiple forest attributes underpin the supply of multiple ecosystem services. Nature communications. 9 (1), 1-11.

Franklin, J.F., Spies, T.A., van Pelt, R., Carey, A.B., Thornburgh, D.A., Berg, D.R., ... \& Bible, K. (2002): Disturbances and structural development of natural forest ecosystems with silvicultural implications, using Douglas-fir forests as an example. Forest Ecology and Management, 155 (1-3), 399-423.

Gustafsson, L., Baker, S.C., Bauhus, J., Beese, W.J., Brodie, A., Kouki, J., .. \& Neyland, M. (2012): Retention forestry to maintain multifunctional forests: a world perspective. BioScience 62 (7), 633-645.

Hobi, M.L., Ginzler, C., Commarmot, B., Bugmann, H. (2015): Gap pattern of the largest primeval beech forest of Europe revealed by remote sensing. Ecosphere, 6 (5), 1-15.

Jaloviar, P., Saniga, M., Kucbel, S., Pittner, J., Vencurik, J., Dovciak, M. (2017): Seven decades of change in a European old-growth forest following a stand-replacing wind disturbance: A long-term case study. Forest Ecology and Management 399 (2017): 197-205.

Juchheim, J., Ehbrecht, M., Schall, P., Ammer, C., Seidel, D. (2019): Effect of tree species mixing on stand structural complexity. For. Int. J. For. Res. 93 (1), 75-83. 
Kimmins, J.P. (2004): Forest ecology. Fishes and forestry: Worldwide watershed interactions and management, $17-43$.

Kucbel, S., Saniga, M., Jaloviar, P., Vencurik, J. (2012): Stand structure and temporal variability in old-growth beech-dominated forests of the northwestern Carpathians: A 40-years perspective. Forest Ecology and Management, 264, 125-133.

Kuuluvainen, T. (2009): Forest Management and Biodiversity conservation based on natural ecosystem dynamics in northern Europe: The complexity challenge. Ambio: A Journal of the Human Environment, 38 (6), 309-315.

Lafond, V., Lagarrigues, G., Cordonnier, T., Courbaud, B. (2014): Uneven-aged management options to promote forest resilience for climate change adaption: effects of group selection and harvesting intensity. Annals of Forest Science, 71, 173-186.

Liira, J., Sepp, T., Parrest, O. (2007): The forest structure and ecosystem quality in conditions of anthropogenic disturbance along productivity gradient. Forest Ecology and Management, 250 (1-2), 34-46.

McElhinny, C., Gibbons, P., Brack, C., Bauhus, J. (2005): Forest and woodland stand structural complexity: Its definition and measurement. Forest Ecology and Management 218, 1-24.

Meyer, P. (2005): Network of strict forest reserves as reference system for close to nature forestry in Lower Saxony, Germany. Forest Snow and Landscape Research, 79 (1/2), 33-44.

Nagel, T.A., Svoboda, M., Diaci, J. (2006): Regeneration patterns after intermediate wind disturbance in an old-growth Fagus-Abies forest in southeastern Slovenia. Forest Ecology and Management, 226 (1-3), 268-278.

Nagel, T.A., Svoboda, M., Kobal, M. (2014): Disturbance, life history traits, and dynamics in an old- growth forest landscape of southeastern Europe. Ecological Applications, 24 (4), 2014, 663- 679.

Nagel, T.A., Mikac, S., Dolinar, M., Klopcic, M., Keren, S., Svoboda, M., Diaci, J., Boncina, A., Paulic, V. (2017): The natural disturbance regime in forests of the Dinaric Mountains: A synthesis of evidence. Forest Ecology and Management 388 (2017), 29-42.

Okuda, T., Suzuki, M., Adachi, N., Quah, E.S., Hussein, N.A., Manokaran, N. (2003): Effect of selective logging on canopy and stand structure and tree species composition in a lowland dipterocarp forest in peninsular Malaysia. Forest Ecology and Management, 175 (1-3), 297-320. 
Petriţan, A.M., von Lüpke, B., Petriţan, I.C. (2009): Influence of light availability on growth, leaf morphology and plant architecture of beech (Fagus sylvatica L.), maple (Acer pseudoplatanus L.) and ash (Fraxinus excelsior L.) saplings. European Journal of Forest Research, 128, 61-74.

Petriţan, I.C., von Lüpke, B., Petriţan, A.M. (2011): Effects of root trenching of overstorey Norway spruce (Picea abies) on growth and biomass of underplanted beech (Fagus sylvatica) and Douglas fir (Pseudotsuga menziesii) saplings. European Journal of Forest Research, 130, 813-828.

Podlaski, R., Sobala, T., Kocurek, M. (2019): Patterns of tree diameter distributions in managed and unmanaged Abies alba Mill. and Fagus sylvatica L. forest patches. Forest Ecology and Management 435, 97-105.

Pommerening, A., Murphy, S.T. (2004): A review of the history, definitions and methods of continuous cover forestry with special attention to afforestation and restocking. Forestry, 77 (1), 27-44.

Puettmann, K.J. (2011): Silvicultural challenges and options in the context of global change: "simple" fixes and opportunities for new management approaches. Journal of Forestry, 109, 321-331.

Puettmann, K.J., Coates, K.D., \& Messier, C. (2012): A critique of silviculture: managing for complexity. Island press.

Raymond, P., Bédard, S., Roy, V., Larouche, C., Tremblay, S. (2009): The irregular shelterwood system: Review, classification, and potential application to forests affected by partial disturbances. Journal of Forestry, 405-413.

Sabatini, F.M., Burrascano, S., Keeton, W.S., Levers, C., Lindner, M., Pötzschner, F., ... \& Debaive, N. (2018): Where are Europe's last primary forests? Diversity and Distributions, 24 (10), 1426-1439.

Schall, P., Gossner, M.M., Heinrichs, S., Fischer, M., Boch, S., Prati, D., ... Buscot, F. (2018): The impact of even-aged and uneven-aged forest management on regional biodiversity of multiple taxa in European beech forests. Journal of Applied Ecology, 55 (1), 267-278.

Schulze, E.D., Bouriaud, L., Bussler, H., Gossner, M., Walentowski, H., Hessenmöller, C., ... \& v. Gadow, K. (2014): Opinion paper: Forest management and biodiversity. Web Ecology, 14, 3-10.

Schütz, J.-P. (1999b): Close-to-nature silviculture: is this concept compatible with species diversity? Forestry, 72 (4), 359-366. 
Schütz, J.-P. (2002): Silvicultural tools to develop irregular and diverse forest structures. Forestry, 75 (4), 329-337.

Seidel, D., Ehbrecht, M., Annighöfer, P., Ammer, C. (2019a): From tree to stand-level structural complexity - Which properties make a forest stand complex? Agricultural and Forest Meteorology, 278, 107699.

Seidl, R., Rammer, W., Lexer, M.J. (2011a): Adaption options to reduce climate change vulnerability of sustainable forest management in the Austrian Alps. Canadian Journal of Forest Research, 41, 694-706.

Storch, F., Kändler, G., Bauhus, J. (2019): Assessing the influence of harvesting intensities on structural diversity of forests in south-west Germany. Forest Ecosystems, 6 (1), 40. 
List of publications 


\section{Journal articles}

Stiers, M., Willim, K., Seidel, D., Ehbrecht, M., Kabal, M., Ammer, C., Annighöfer, P. (2018): A quantitative comparison of the structural complexity of managed, lately unmanaged and primary European beech (Fagus sylvatica L.) forests. Forest Ecology and Management, 430, 357-365.

Stiers, M., Willim, K., Seidel, D., Ammer, C., Kabal, M., Stillhard, J., Annighöfer, P. (2019): Analyzing spatial distribution patterns of European beech (Fagus sylvatica L.) regenerations in dependence of canopy openings. Forests, 10, 637.

Stiers, M., Annighöfer, P., Seidel, D., Willim, K., Neudam, L., Ammer, C. (accepted for publication): Quantifying the target state of forest stands managed with the continuous cover approach - revisiting Möller's "Dauerwald" concept after 100 years. Trees, Forests and People 1 (2020), 100004

Willim, K., Stiers, M., Annighöfer, P., Ammer, C., Ehbrecht, M., Kabal, M., Stillhard, J., Seidel, D. (2019): Assessing understory complexity in beech-dominated forests (Fagus sylvatica L.) in Central Europe - from managed to primary forests. Sensors, 19, 1684.

Willim, K., Stiers, M., Annighöfer, P., Ehbrecht, M., Ammer, C., Seidel, D. (in review): Spatial patterns of structural complexity in differently managed and unmanaged beechdominated forests in Central Europe. Remote Sensing.

Seidel, D., Annighöfer, P., Stiers, M., Zemp, C.D., Burkhardt, K., Ehbrecht, M., Willim, K., Kreft, H., Hölscher, D., Ammer, C. (2019): How a measure of tree structural complexity relates to architectural benefit-to-cost ratio, light availability, and growth of trees. Ecology and Evolution, 00, 1-9.

\section{Submitted articles}

Annighöfer, P., Stiers, M., Seidel, D., Willim, K., Neudam, L., Ammer, C. (in review): Über die Quantifizierbarkeit einer 100-jährigen Idee. 100 Jahre Dauerwald. AFZ- Der Wald.

Ehbrecht, M., Seidel, D., Annighöfer, P., Kreft, H., Köhler, M., Zemp, D.C., Puettmann, ..., Stiers, M., ... \& Ammer, C. (in review): Global patterns and climatic controls of forest structural complexity. Nature Communications. 
Danksagung / Acknowledgements 


\section{Danksagung / Acknowledgements}

Rückblickend möchte ich mich bei einigen Personen bedanken, ohne die diese Doktorarbeit nicht möglich gewesen wäre. Erinnere ich mich an den Anfang meiner Promotion, so möchte ich mich zuallererst bei Dr. Sabine Ammer bedanken. Ohne das Vertrauen, welches Sie in mich gelegt haben, würde ich jetzt nicht an dieser Stelle stehen. Im selben Atemzug möchte ich mich natürlich bei meinem Doktorvater Prof. Dr. Christian Ammer bedanken. „Danke“ für das entgegengebrachte Vertrauen, die stets angenehme Arbeitsatmosphäre sowie den großartigen wissenschaftlichen Input. Auch möchte ich mich dafür bedanken, dass bei Ihnen, auch im zunehmend anonymeren Universitätsgeschehen, in dem die Studierenden oft nicht mehr sind als eine Matrikelnummer, die Menschlichkeit niemals zu kurz kam. Ich bin außerordentlich dankbar dafür, Ihnen beiden im Laufe meiner Studienzeit begegnet zu sein!

Darüber hinaus möchte ich mich bei Dr. Dominik Seidel und Prof. Dr. Peter Annighöfer bedanken. Eure Hilfe, Unterstützung und Geduld haben maßgeblich zur Fertigstellung dieser Arbeit beigetragen. „Danke“ für die unkomplizierte Betreuung, die zahlreichen, oft stundenlangen Meetings, die konstruktive Kritik, die unermüdliche Motivation und den stets freundlichen Umgang. Ohne euren Einsatz wäre das Projekt „StrukMana“ wohl nur halb so erfolgreich gewesen!

Ebenso bedanken möchte ich mich bei Katharina Willim ohne die die letzten 3 Jahre freudloser verlaufen wären. „Danke“ für all die unzähligen Tage und Stunden, die wir gemeinsam im Wald verbracht haben, für die vielen Erlebnisse, dein offenes Ohr und die vielen Gespräche. Es war schön, dich als „Leidensgefährtin“ zu haben!

Weiterhin möchte ich Liane Neudam danken, die ebenfalls viele Stunden mit mir im Wald zugebracht und mir bei der Datenaufnahme geholfen hat. Danken möchte ich auch allen anderen Doktoranden der Abteilung für die vielen fachlichen und auch nichtfachlichen Diskussionen. Ein weiteres „Danke“ gilt Silke Marks für ihre Hilfe bei der schier endlosen Flut an Arbeitsverträgen, Reisekostenabrechnungen und sonstigen bürokratischen Herausforderungen, sowie dem gesamten Kollegium der Abteilung Waldbau und Waldökologie der gemäßigten Zonen für den netten Umgang. Ich hoffe, dass sich unsere weiteren Wege noch das ein oder andere Mal kreuzen werden. 
Außerdem danken möchte ich allen Personen, die die Datenaufnahme möglich gemacht haben, uns bei der Flächenauswahl beraten oder Zugangsgenehmigungen ausgestellt haben. „Danke“ an all jene, die im Hintergrund assistierten, unterstützten oder mir in jedweder Form in den letzten Jahren mit Rat und Tat zur Seite gestanden haben.

Des Weiteren möchte ich auch meinen Eltern Heinz und Doris Stiers danken ohne die ich nicht an diesem Punkt wäre. Nicht nur, weil sie mir mein Studium ermöglicht haben, sondern auch weil sie mich in jeglicher Situation und jeder Entscheidung unterstützt haben.

Zum Abschluss möchte ich mich bei Philipp Conrad bedanken, der mir mit seiner grenzenlosen Positivität und seinem Optimismus stets geholfen hat, die Hoffnung und Zuversicht nicht zu verlieren. Ich danke dir dafür, dass du immer an mich glaubst! 
Appendix 


\section{Declaration of originality}

I, Melissa Stiers, hereby declare that I am the sole author of this dissertation entitled "Quantifying stand structure and structural complexity along a management gradient in temperate forests". All references and data sources that were used in the dissertation were appropriately acknowledged as such.

I further declare that this work has never been submitted elsewhere in any form as part of any other dissertation procedure.

Melissa Stiers

Göttingen, den 25.09.2020 